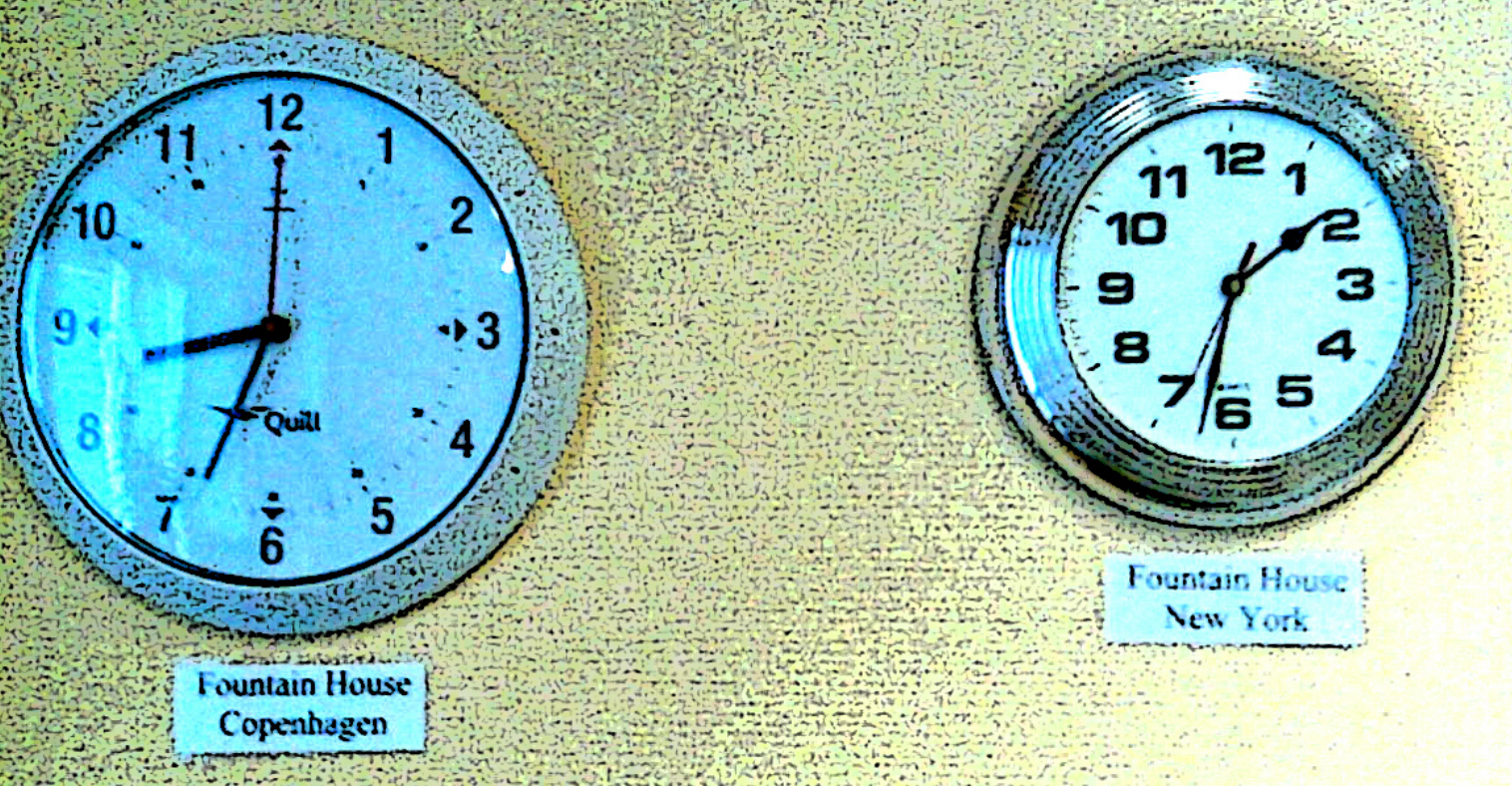

2.2.5.

\title{
ANNEMARIE HØJMARK
}

\section{THE FOUNTAIN HOUSE WAY}

TO BERETNINGER FRA HVERDAGSLIVET I TRE KLUBHUS SETTINGS I DANMARK 



\section{The Fountain House Way}

To beretninger fra hverdagslivet i tre Klubhus settings i Danmark 

Annemarie Højmark

\section{The Fountain House Way}

\section{To beretninger fra hverdagslivet i tre Klubhus settings i Danmark}


The Fountain House Way

- To beretninger fra hverdagslivet i tre Klubhus settings i Danmark

Titel:

The Fountain House Way - to beretninger fra hverdagslivet i tre Klubhus settings i Danmark

Forfatter:

Annemarie Højmark

Udgivet af:

Institut for Uddannelse og Pædagogik (DPU), Aarhus Universitet.

Forskningsprogrammet SSIP - Social- og Specialpædagogik i Inkluderende Perspektiv. 2011

(c) 2011, forfatteren

1. udgave

Kopiering tilladt med tydelig kildeangivelse

Omslag og grafisk tilrettelæggelse: Knud Holt Nielsen

ISBN: 978-87-7430-261-2 (elektronisk udgave)

DOI: $10.7146 /$ aul.46.32

The Fountain House Way - to beretninger fra hverdagslivet i tre Klubhus settings i Danmark er en selvstændig rapport udarbejdet i forbindelsen med projektet 'Fontænehusene Danmark'. Forskningsprojektet påbegyndtes i februar 2010 og afsluttedes i oktober 2011 med 'Fontænehusene Danmark' som opdragsgiver og Social- og Integrationsministeriet som bevillingsgiver med en mindre medfinansiering fra DPU/Aarhus Universitet. Projektet er gennemført under DPU's forskningsprogram 'Social- og specialpædagogik i inkluderende perspektiv' (SSIP) af videnskabelig medarbejder Cand. Pæd. i pædagogisk antropologi Annemarie Højmark, lektor Niels Rosendal Jensen og lektor Søren Langager (projektansvarlig).

Publikationen er udgivet i serien 'Socialpsykiatri og Socialpædagogik' (serieredaktør: Søren Langager) under forskningsprogrammet 'Social- og specialpædagogik, inklusion og ledelse af organisationer' (SILO) ved Institut for Uddannelse og Pædagogik (DPU), Aarhus Universitet. Denne og øvrige udgivelser i serien kan gratis downloades via adressen: www.edu.au.dk/silo/ebog. Serien består af rapporter fra forskningsprojekter og bemærkelsesværdige lettere omarbejdede specialeafhandlinger 


\section{Indhold}

INTRODUKTION - AFGRAENSNING AF FELTEN

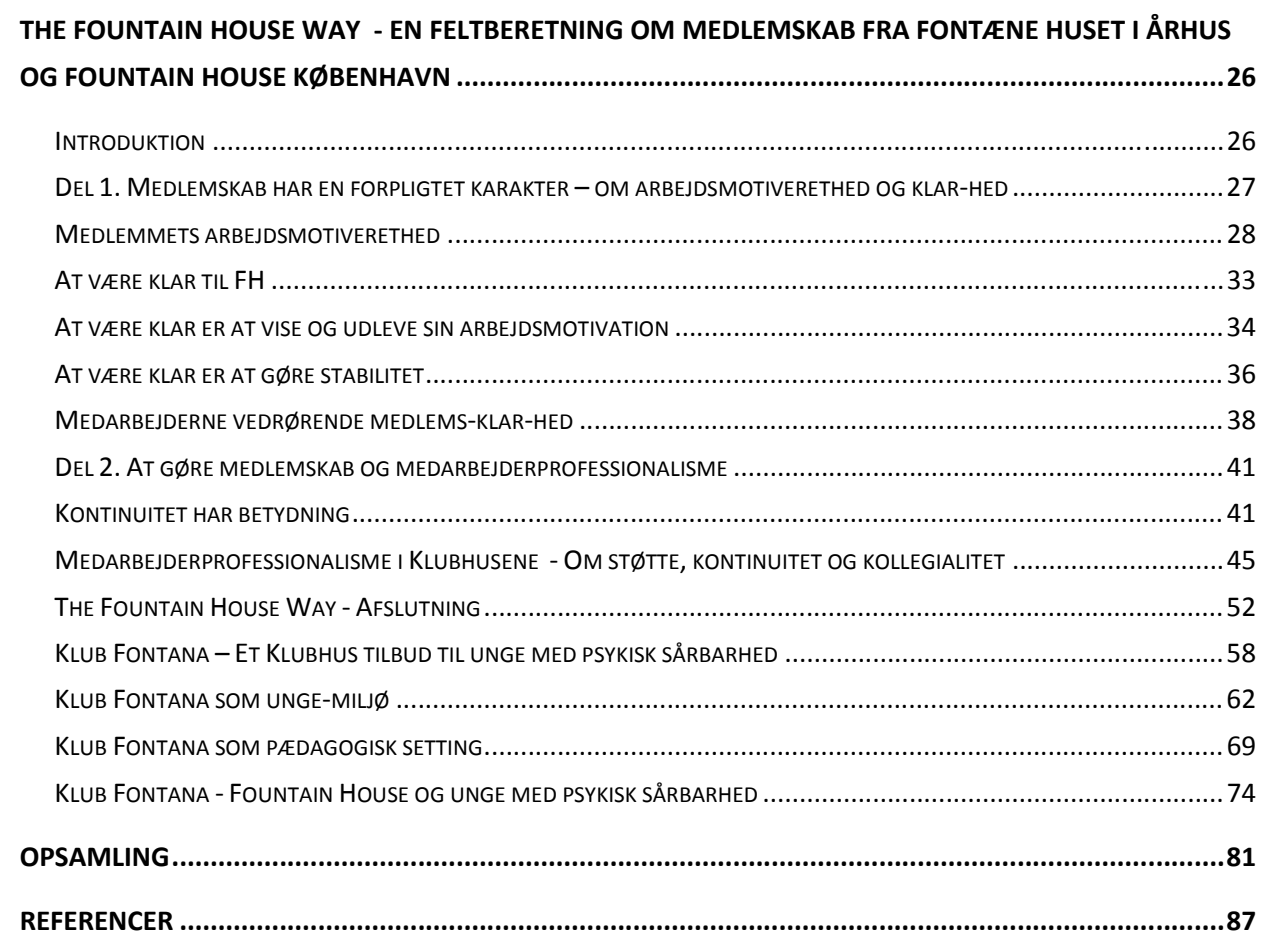





\section{Introduktion - afgrænsning af felten}

Opdraget til den antropologiske del af Projekt Fontænehusene Danmark var, som del af den samlede afrapportering ${ }^{1}$, at formidle et praksisnært indblik i hverdagslivet, som det leves af medlemmer og medarbejdere inde i tre udvalgte Klubhuse. Det er henholdsvis Fontæne Huset i Århus, Fountain House København og ungeklubben Klub Fontana i Fountain House København. Hertil kommer besøg i Kildehuset i Nørresundby².

Som sådan er kapitlet her orienteret om mønstre og sammenhænge ved hverdagslivet inde i Klubhusene. Forholdet med omverdenen er altså ikke i fokus, selv om det er et tema, der gøres opmærksom på, alle de steder jeg har besøgt $^{3}$. Men der er alligevel en væsentlig 'indad-udadrettethed', som skal nævnes her i den afgrænsende introduktion. Det er forholdet med den model eller standarderne for organisering og samvær, som Klubhusene fungerer efter.

Feltstudierne viser nemlig, at et Klubhus er en social kontekst indadtil, som signalerer indre samhørighed, men der er også tilhørsforhold udadtil med

1 Annemarie Højmark, Niels Rosendal Jensen og Søren Langager (2011). Selvfølgelige forventninger - Fontænehusene som psykosocial rehabiliteringsmodel. København: DPU/AU.

2 Mine besøg i Kildehuset i Nørresundby var ikke i udgangspunktet tænkt som egentlige feltstudier (men blev dog minifeltstudier) og er derfor kun sporadisk inddraget her i kapitlet.

${ }^{3}$ Det betyder ikke, at Klubhusene og menneskene derinde ikke er orienteret 'udad'. Det er i forhold til at komme 'videre', at der kan være problematiseringer: "Det er godt nok med før, og herinde - med Fountain House, ja, her får jeg noget struktur og dagen organiseret, men hoad med bagefter? Det synes jeg er det store spørgsmål"(Bjørn, medlem FH K). I en samtale om fremtidsmuligheder med en af de unge medlemmers sagsbehandler siger en medarbejder: "Nu har Vilhelm øvet sig på virkeligheden herinde et godt stykke tid, derfor giver det ikke mening at sætte ham til at skrue pærer $i$ herinde længere; han skal ud nu" (Ejvind medarbejder Klub Fontana FH K). Orienteringen ud af Klubhusene handler også om, hvordan Klubhusene skal forholde sig til medlemmernes liv i det hele taget. ."De fleste har jo også en tilknytning til lokalpsykiatrien Bostøtter og sådan. Så det er mest, hvordan medlemmet har det her i Fontæne Huset, vi går ind i", forklarer Betty (medarbejder FH $\AA$ ) om deres opgave som medarbejdere i Fontæne Huset i Århus. I Kildehuset i Nørresundby, er der videre rammer for, hvordan medarbejderne yder støtte til det enkelte medlem ud af huset: "Det er helhedssynet på medlemmet der er i fokus. Derfor er der flydende grænser for vores omsorg. Vi er faktisk til rådighed 24 timer $i$ døgnet, hois der er behov for det" (medarbejder FH N). Et medlem i Fountain House København fortæller, at "Jeg er overbevist om, at medlemmerne ikke går til medarbejderne med 'hvad som helst', for vi kan jo sagtens se, at de er stressede og har meget om ørerne" (Lisbeth, medlem FH K), mens et andet medlem præcist peger på medlemmernes muligheder for at få støtte i forhold til omverdenen: "Vi har jo netop socialrådgiverne $i$ huset, som vi kan bruge til kontakt med kommunen og sådan" (Marianne, medlem FH K). 
alle de andre Klubhuse nationalt og internationalt, som abonnerer på samme model for organisering og samvær.

Som et af medlemmerne gjorde mig opmærksom på: "Det er sjovt, at uanset hvilket Klubhus jeg besøger i verden, så ved jeg, at jeg vil kunne indgå uden problemer, for selv om der er noget, der er forskelligt, så er det helt basale alligevel det samme - på en måde" (Gertrud", medlem FH Å). Det erfarede jeg selv på nationalt plan, efterhånden som jeg, som projektet skred frem, stiftede bekendtskab med flere Klubhuse.

Samhørigheden, som den omtales og leves i hverdagen, viser den udefrakommende, at der er tale om et tilhørsforhold, der er vigtigt for selvforståelsen i Klubhusene. Når man træder ind i den sociale felt, et Klubhus er, demonstreres samhørigheden i form af organiseringer efter modellen/standarderne fra allerførste øjeblik. Det vil sige, at ens egen tilstedeværelse også bliver en tilstedeværelse i modellens elementer.

Tilstedeværelsen tager form efter husets praktiske tolkning, altså den lokale fortolkning, af den model feltens mennesker er sammen om at praktisere i den fysiske ramme (Klubhuset), der er afgrænsning om deres arbejdsomme og sociale hverdagsliv sammen. Allerede i mine forhandlinger om adgang måtte jeg, både i Fontæne Huset i Århus og I Fountain House København, således omkring de store Husmøder, hvor alle medarbejdere og medlemmer er med til introduktion, drøftelse og beslutning af nye tiltag. Og der måtte holdes adskillige yderligere møder i Fountain House København, før den 'endelige' formelle adgang til mit feltstudie i huset var etableret. Jeg mødte så at sige Klubhusmodellen i selve min indtræden, med den flade organisering, ligeværdigheden, struktureringen, omgangsformerne, frivillighed og organiseret dagligliv, som jeg senere kom til at lære at kende i sin mellemmenneskelige kompleksitet og rummelighed.

Men nok så vigtigt er det altså også, at samhørigheden udtrykker et vedvarende arbejde $\mathrm{i}$ Klubhusene med at forholde sig til det enkelte hus forbundethed udadtil - ikke med omverdenen i almindelighed, men med det større nationale og internationale Klubhusfællesskab. 'Falder det vi gør (tilstrækkeligt) indenfor?', drøftes det for eksempel i modelmøder og i danskklubhustræning.

En medarbejder fortalte, at "Nogle af de medlemmer, der har været her længst kan finde på at sige 'Hov, det her er da mod standarderne' - og det er jo godt, de siger

\footnotetext{
${ }^{4}$ Medlemmer og medarbejdere er anonymiseret med opfundne navne. FH $\AA$ er forkortelse af Fontæne Huset i Århus. FH K er forkortelse af Fountain House København. Jeg bruger forkortelsen FH som generel betegnelse, sådan at læsere fra de respektive huse selv kan anvende enten den engelske betegnelse eller den danske oversættelse, når de læser. Jeg bruger også samlebetegnelserne "Fontæne Klubhuse" og "Klubhuse" om de huse, jeg har besøgt.
} 
det. Og hvis vi sidder og snakker på Onsdagsmødet ${ }^{5}$ for eksempel, så kan det godt være, vi pludselig stopper op, og en siger, 'Den her snak kan vi da ikke have i det her forum', fordi vi tager jo os selv $i$, at vi var $i$ gang med at gøre noget, som hører til $i$ et andet forum her i Fontæne Huset, hois man skal leve op til vores model " (Knud, medarbejder FH $\AA$ ).

I mit arbejde med at undersøge hverdagslivet indefra, var jeg på ingen måde ubevidst om den gennembeskrevne sociale og organisatoriske kontekst, som samspil mellem medarbejdere og medlemmer foregår inden for, med modellen, standarderne, og husenes og 'bevægelsens' lange historie. For det er vigtigt, at være opmærksom på, hvad det er for en fysisk, organisatorisk og institutionel kontekst, man træder ind i. Men jeg gik til min del af projektet for at undersøge hverdagsliv og samspil - og det præcist, hverken mere eller mindre.

Eller sagt med andre ord: Jeg ville ikke lade de 36 standarder være figuren på baggrunden 'praksis i organisationen Fontæne Klubhuse'; men lade min figur være samspil mellem medlemmer og medarbejdere på baggrunden 'danske Klubhuse, som de opleves ved selvsyn med bevidsthed om den model, de eksisterer efter', som hverdagslivet kan undersøges af en udefrakommende, der udforsker indefra.

Herunder følger først metodiske og etiske overvejelser over det at bedrive feltstudier i Fontæne Klubhusene samlet set, derefter følger præsentation af Klubhusene i henholdsvis Købehavn og Århus og feltberetning fra Klubhusene, mens Klub Fontana præsenteres særskilt i forbindelse med feltberetningen derfra. Til slut følger en afrunding.

\section{Feltstudier i Fontæne Klubhusene - nogle metodiske overvejelser}

Feltberetningens formål er som sagt at formidle et praksisnært indblik i noget af det, der er på spil i hverdagens samspil i de forskellige dele af de danske Klubhuse, jeg har bedrevet feltstudier i.

Ambitionen om at formidle et praksisnært indblik i hverdagslivet betyder en undersøgelsesstrategi, der netop starter ved samspillet selv. Det vil sige ved træffene mellem medlemmer og medarbejdere i deres virke inde i Klubhusene.

For at operationalisere min del af opgaven om at indfange praksis via studier af samspil mellem medarbejdere og medlemmer, konstruerer jeg medarbejder- og medlemskategorierne, som eksisterer som virkelige positioner i felten, som antropologiske relationelle kategorier (Wadel 1991:77, 92f).

\footnotetext{
5 Onsdagsmødet er det ugentlige medarbejdermøde i FH $\AA$ åbent for men i praksis uden deltagelse af medlemmer.
} 
Det vil sige, at medlemmer og medarbejdere forstås som medlemmer og medarbejdere i kraft af deres samspil, som de gør samspil i ord og handling. Det er viden om samspil, der skal føre til viden om Klubhuspraksis - altså om Fontæne Klubhuse som ramme om og social sammenhæng for medlemmernes rehabilitering. Det feltens mennesker gør sammen i ord og handling, kan forstås som medarbejdernes fortolkning af deres professionelle opgave, og som medlemmernes behov for deltagelse i et fællesskab med erfaringsligestillede og professionelle, med det det kan bibringe i deres liv med eller ud af sindslidelse/psykisk sårbarhed.

Således er det deres samspil, der gør dem til medlemmer og medarbejdere. Deres medlems- og medarbejderidentitet ses altså ikke som iboende egenskaber hos dem 'hver for sig', men som noget de bliver og kan identificeres som i deres virke i Klubhusene, med modellen/standarderne, og i deres virke med hinanden.

'Det antropologiske' er således ikke noget, feltarbejderen går ud og samler op (Broe 2003: 321), men det antropologiske ved livet i Fontæne Klubhusene. Det kan kaldes en multi-sited forskningsstrategi om at forfølge samspil (Marcus 1998) ${ }^{6}$ : Medarbejdere og medlemmer besidder sammen forudsætningerne for at gøre medlemskab og medarbejderprofessionalisme og dermed Klubhuspraksis, som kan undersøges med antropologiske undersøgelsesmåder. Det vil sige med deltagende observation. Således er ambitionen, at producere viden om, hvordan Klubhusene arbejder i praksis med rehabilitering med det individuelle medlem i centrum og så modellens fokus på fællesskab og samarbejde.

Feltstudiemetodisk viste konstruktionen, af medarbejdere og medlemmer som dem, der med deres forskellige (men etablerede/eksisterende) sociale positioner i felten 'gør' klubhushverdagsliv, sig som en udfordring. For i praksis er det præcist et grundlæggende træk i Klubhusene, at medarbejdere og medlemmer er, indgår i og handler som ligeværdige parter i det daglige arbejde og sociale liv, som hverdagen er organiseret $i$.

Det betød, at jeg kunne observere og deltage i samspil i form af arbejdsopgaver og socialt liv i husene med medarbejderne og medlemmerne, men det var i flere tilfælde først ved nærmere bekendtskab, at jeg fandt ud af, hvem der var medarbejdere, og hvem der var medlemmer. Jeg havde ikke 'travlt' med at afdække det (så kunne jeg jo bare spørge direkte). Nej, jeg ville se, når det nu ikke var entydigt 'tydeligt', hvad der gjorde det tydeligt. For denne 'afsøgning' i feltstudiet af hvem der besidder de eksisterende positioner, og dermed hvad positionerne består $\mathrm{i}$, og hvordan livet er organiseret efter det - hvordan positionerne gøres som forskellige, i samspil med hinanden, eller på

${ }^{6}$ Det er, som det fremgår nedenfor, at forfølge medlemskab og medarbejderprofessionalisme ind og ud og på kryds og tværs af FH-tilbud og analytisk konstruerede 'spaces', hvor de agerer som sådan. 
tværs af organiseringen, er i sig selv en væsentlig første-viden om klubhuspraksis, som man aldrig kan få, når 'det hele' er afdækket.

I den sidste del af feltstudierne og i det analytiske arbejde hjemme ved skrivebordet er det klarlagt, 'hvem der er hvem', og positionerne forstået som sociale kategorier bruges til at forstå praksis med jf. opdraget og den konstruerede analytiske strategi.

I Klub Fontana gjorde det sig ikke gældende på samme måde, at positionerne medlem og medarbejder var 'slørede'. Der er synlig aldersforskel mellem medarbejdere og medlemmer, og aktivitetsforskelle mellem hvad medlemmer og medarbejdere gør og hvad deres indbyrdes roller heri er. Men i selve analysen, hvor jeg fremanalyserede Klub Fontana som henholdsvis et ungemiljø, en pædagogisk setting og et Fountain House tilbud, kom 'nye perspektiver' til de analytiske kategorier (medlem og medarbejder). Medarbejderne er i mere klassisk forstand 'ansatte medarbejdere' end i Klubhusene generelt; men da jeg analyserede mit materiale med henblik på Fontana som ungemiljø, tænkte og skrev jeg fortrinsvis om de unge medlemmer som 'de unge'. I Klub Fontana som Fontæne Klubhustilbud for unge med psykisk sårbarhed tænkte og skrev jeg først og fremmest om de unge medlemmer som 'medlemmer'. I Fontana som pædagogisk setting brugte jeg en kombination, og det var her medarbejdernuancerne kom rigtigt frem - Jeg havde kategorier som 'voksne' og 'lærere' i spil i analysearbejdet.

Når der er fokus på medlemmernes position som for eksempel i analysen af Klub Fontana som Fountain House tilbud kommer samspil til syne på en anden måde, end når fokus er på de unge i Fontana som pædagogisk setting. Fordi det at være medarbejder over for det at være medlem i et Klubhus er noget andet end det at være 'voksne' overfor unge i en pædagogisk setting.

Den information, der ligger i nuancerne i medlems- eller medarbejderkategorierne når fokus er på samspil, er værd at være opmærksom på, fordi viden om positioner indebærer viden om samhandlingsmuligheder for de positionerede mennesker - altså medlemmerne og medarbejderne.

\section{Roller i felten}

I mine bestræbelser på at producere viden via deltagende observation, hvor jeg involverer mig i hverdagslivet som det foregår i samspil mellem medarbejdere og medlemmer i Klubhusene, arbejdede jeg med at finde måder at indgå på, som ikke skilte sig for meget ud fra de eksisterende levede positioner i felten, men som på den anden side heller ikke slørede min identitet for mig selv og for feltens mennesker som en, der både skal forholde mig med indlevende nærhed og med analytisk distance. Det vil sige, at jeg arbejdede med at finde legitime positioner i samspillet mellem medlemmerne og medarbejderne. 
"Den måde, man aflæser og indgår i rummets kommunikation og rollefordeling på, har altså indflydelse på, hvilke erfaringsperspektiver man får viden om. Feltarbejde giver ikke mulighed for deltagelse $i$ alt hele tiden, men kun for delvis eller positioneret deltagelse" (Gulløv \& Højlund 2003:112-3)

Medlemmerne og medarbejderne i Klubhusene er sammen i det arbejdsorganiserede Dagsprogram. Som det hedder i Fountain House organisationens internationale standarder under punkt nr. 18:

"Klubhuset er organiseret $i$ en eller flere arbejdsenheder, som hver især har en tilstrækkelig medarbejderstab, antal medlemmer samt meningsfyldte arbejdsopgaver til at opretholde en hel og engagerende arbejdsdag. Der afholdes enhedsmøder med henblik på at udvikle såvel fxllesskabsfølelse som at organisere og planlegge dagens arbejde"7.

Opmærksomheden i den praksis jeg mødet inde i Klubhusene på det arbejdsorganiserede Dagsprogram gjorde, at jeg gerne ville indgå i Dagsprogrammet. For ved at indgå i deres organisering og omgangsformer, kunne jeg (med samtidig og efterfølgende analytisk distance til det oplevede) gøre indsigt $i$, hvordan samspil foregår og hvordan det giver mening.

De fleste arbejdsopgaver i Enhederne er eftertragtede, og antallet af medlemmer stemmer overens med, hvor mange man i en ligeværdigheds ånd med medarbejderne kan være beskæftiget med meningsfulde (nødvendige, nyttige) opgaver. Det vil sige, at jeg ikke kunne byde 'rent' ind og indgå 'på lige fod' i arbejdsfællesskabet. Men eftersom jeg var interesseret i samspil, forsøgte jeg at finde steder, hvor det var muligt at byde ind og samarbejde om opgaver.

Somme tider blev jeg indbudt til deltagelse: "Enhedsmøde, det er noget, $d u$ kan være med til Annemarie" (Sigfred, medlem FH K). Eller "Jeg synes du skal vælge dagens citat" (Jes, medlem FH Å). Eller "Er du tilgængelig til en opgave med Kalle" (Anker, medarbejder FH Å). En dag vi skulle i receptionen, sagde Asta (medlem FH Å) "Så kan du skrive i fødselsdagsfeltet [på oversigtstavlen over dagen $\mathrm{AH}]$, for jeg kan ikke lide at skrive min egen fødselsdag" - Sådan bliver legitime positioner til i samspil og giver viden om samspils betydning. Her, hvordan vi i den delte arbejdsopgave kan være nyttige for hinanden. Andre gange var det ikke muligt: "Nej, den her opgave kan man ikke være to om" (Filippa, medlem FH K). Så er det tid til mere tilbagetrukket tilstedeværelse.

I Klubhusene er det vigtigt at yde sit bidrag til driften af huset og at samarbejde. Jeg lærte om det gennem mine egne oplevelser gjort gennem deltagelse via roller i felten. "Hvordan er din strategi? Altså hvordan vil du

\footnotetext{
${ }^{7}$ Retningslinjer for klubhuse.
} 
involvere medlemmer? Du kan sige 'Jeg har brug for hjælp', for så vil der være åbnet for, at et medlem kan føle sig nyttig" lærer Frans (medarbejder FH K) mig, da jeg har påtaget mig en knap så attraktiv rengøringsopgave til fordelingen på enhedsmødet. Der havde jeg pludselig en position nærmere medarbejdernes end medlemmernes. Jeg har også deltaget $\mathrm{i}$ at male vægge, vasket op, vasket gulv, pudset spejle, lavet motion, ordnet postforsendelse, møde-diskussioner, supervision mv. sammen med medlemmer og medarbejdere. Nogle gange på eget initiativ, andre gange fordi lejlighed bød sig via et medlem eller en medarbejders blik for mine måder at være der.

En antropologs oplæring til at være feltarbejder i Klubhusene foregår fra første kontakt (når måden at tænke praksis på præsenteres "Her er alle hinandens kolleger"), i forhandling af formel adgang (der skal holdes de rigtige møder, introduceres på den rigtige måde mv.), når man bliver introduceret og skal 'finde sin vej' ("Nu ved du, hvad du skal bagefter"), ved deltagelsen/inddragelse i arbejdsopgaver ("Tag dig bare den tid, det tager"), i opbygning af samarbejdsrelationer ("Skal vi gøre det sådan, at du holder og jeg skraber ..."), når man skal blive del af organiseringen ("Nu er der ikke pause mere, nu skal vi rejse $\left.o s^{\prime \prime}\right)$ og så videre.

Programmet for feltstudierne så ud på følgende måde:

\begin{tabular}{|c|c|c|c|c|}
\hline Marts 2010 & April 2010 & Maj 2010 & Juni 2010 & Juli 2010 \\
\hline $\begin{array}{l}\text { Uge 9: Forbes } \varnothing \mathrm{g} \\
\text { FH Å }\end{array}$ & Uge 14 & Uge 18 & $\begin{array}{l}\text { Uge 22: } \\
\text { opfølgende } \\
\text { feltstudie FH A + } \\
\text { gruppesamtaler }\end{array}$ & Uge 27 \\
\hline $1 / 2$ uge $10:$ FH Å & $\begin{array}{l}\text { Uge 15: FH K } \\
\text { (Kontoret) }\end{array}$ & Uge 19 & $1 / 2$ uge $23 \mathrm{FH} \mathrm{N}$ & Uge 28 \\
\hline Uge 11: FH Å & $\begin{array}{l}\text { Uge } 16 \text { FH K } \\
\text { (Klub Fontana) }\end{array}$ & Uge 20 & Uge 24 & Uge 29 \\
\hline $\begin{array}{l}1 / 2+1 / 2 \text { uge } 12: \mathbf{F H} \\
\AA ̊ \\
\AA\end{array}$ & Uge 17 & $\begin{array}{l}\text { Uge 21: } \\
\text { epfølgende } \\
\text { feltstudie FHK }\end{array}$ & Uge 25 & Uge 30 \\
\hline Uge 13 & & & Uge 26 & \\
\hline
\end{tabular}

Som oversigtsskemaet viser, besøgte jeg Fontæne Huset i Århus i samlet tre uger, mens jeg var i Fountain House København i godt to uger (medregnet to dages forbesøg). I uge 23 besøgte jeg Kildehuset i Nørresundby et par dage.

Under feltstudierne i Århus var det planen at være tilnærmelsesvis lige meget i henholdsvis Køkken-, Pedel- og Kontorenheden; men grundet svingende medlemsfremmøde var jeg en lille overvægt af tiden i Kontorenheden, ud fra en strategi om at 'forfølge flest mulige medlemmer'. 
Anden gang jeg var i Fontæne Huset i Århus, afbalancerede jeg 'skævvridningen' ved at bevæge mig mere frit mellem Enhederne, end jeg havde gjort i første omgang. Alle var nu vant til min tilstedeværelse og de gjorde mig hele tiden opmærksom på, hvilke forskellige møder og aktiviteter der foregik på kryds og tværs i huset. På dette opfølgende feltarbejde åbnedes dørene altså helt, og derved blev jeg på mange forskellige måder deltager i både enhedsarbejde, pauser, temadag, møder i huset, fredagsafslutning og medarbejdernes supervision.

I løbet af det opfølgende feltarbejde i Fontæne Huset i Århus lavede jeg, for at give plads for det hidtil upåagtede, to gruppesamtaler med samlet syv medlemmer, som meldte sig selv til at deltage. Samtalerne varede knap 30 minutter hver. Medlemmerne indvilgede i at drøfte nogle løst strukturerede emneområder, som jeg på det tidspunkt var optaget af i mine analyser. Samtalerne blev optaget digitalt og er transskriberet. Når jeg anvender citater fra gruppesamtalerne i feltberetningen er de markeret med ' $G+$ dato' i forhøjet tekst. Citater fra hverdagslivets samspil, har jeg forsøgt at gengive så nær det sprog, der blev anvendt i situationen - nogle gange direkte nedskrevet i situationen, andre gange som husket i efterfølgende notattagning og dagbog ${ }^{8}$.

Feltstudierne i København blev tilrettelagt i et samspil mellem projektgruppen, Fountain House og mig på baggrund af forbesøget. Det er et stort hus, og vi besluttede, at for at jeg kunne opnå den ønskede fordybelse i samspillet, var det mest hensigtsmæssigt, at jeg fokuserede på to Enheder. Udspillet var, at den ene skulle være Klub Fontana (for de 18-25årige) og den anden en af Enhederne i det centrale Fountain House.

Valget faldt på Kontorenheden, fordi det var den enhed, vi blev enige om, at jeg på den relativt korte tid til rådighed, kunne lære mest om, hvad Fountain House Købehavn, som et Klubhus i Danmark, er. Det viste sig at være en klog beslutning, da begge medarbejdere var i Enheden hele ugen, der kom en del af de etablerede medlemmer i ugens løb, og der foregik modtagelse/introduktion af fire nye medlemmer.

Jeg forsatte grundlæggende mit arbejde fra Fontæne Huset i Århus i Kontoret i Fountain House København med at have min opmærksomhed rettet mod, hvordan jeg kunne drage fordel af de to steders forskelligheder, således at viden derfra kunne supplere og uddybe indsigter fra det 'modsatte' sted. Denne strategi blev forstærket ved, det opfølgende feltstudie i Fontæne Huset i Århus ${ }^{9}$.

I Klub Fontana, hvor jeg også tilbragte en uge, var oplevelsen allerede på forbesøget, at jeg var kommet til et ganske anderledes sted end i 'de ordinære

\footnotetext{
${ }^{8}$ Jeg førte både feltnotesbog under feltstudierne og dagbog når jeg kom hjem.

${ }^{9}$ Det lykkedes ikke at få en aftale om et opfølgende feltstudie med Fountain House København. Metodisk brugte jeg derfor besøget i Kildehuset i Nørresundby til at se mine foreløbige analyser efter i sømmene.
} 
Fontæne Huse', selv om Klub Fontana ligger i samme bygning og har samme ledelse som Fountain House København. Det gjorde, at jeg metodestrategisk delte min uge der op i følgende delfokusområder i min forfølgelse af samspil: Den først dag (mandag) var 'oplevelsesorienteret', tirsdag forfulgte jeg de unge medlemmers veje, onsdag forfulgte jeg medarbejdernes veje, torsdag forfulgte jeg pædagogikken og fredag var jeg igen oplevelsesorienteret - nu med indsigterne fra ugens forskellige strategier. Medarbejderne var meget interesserede i min 'intensitetsstrategi' og hjalp med adgang til det, der foregik i relation til 'dagens fokus'.

Jeg forsøgte altså at udvikle mine metoder undervejs til at etablere feltarbejdets ønskelige intensitet i den meget korte tid til rådighed, som ses ikke bare i dette projekt, men må ses som et vilkår i tidens projektansættelser.

\section{Etik i forskningsprocessen}

"Pas på, vi bliver observeret" - "Nej, hun har ikke notesbog med, se selv" (medarbejdere FH K)

De metodiske overvejelser i forbindelse med feltstudiedelen af projektet indebærer i høj grad overvejelser af etisk karakter. Det er overvejelser over, hvad min egen indtræden betyder - altså hvordan min deltagelse påvirker samspillet i felten, og den viden der ligger i egen påvirkning.

I præsentationen af projektet bed jeg mærke i, at der på den ene side blev lagt vægt på, at det er Husene/Fonden selv, der har ønsket projektet iværksat, sammen med at det var tydeligt, at Klubhusmodellen overordnet betragtet fokuserer på mulighed for rehabilitering ${ }^{10}$ ved sindslidelse. Som sådan var adgangen ukompliceret, idet ønsket om en undersøgelse kom indefra og forståelsen indefra, af de mennesker undersøgelsen kommer tæt på, er deres ressourcer. Hermed reduceres sårbarheden - i hvert fald i udgangspunktet.

Men mødet med 'virkeligheden' spiller en stor metodisk/etisk rolle, for jeg mødte, på forskellig måde menneskeligt set nogle 'stille felter'. Jeg opfattede det som møder med mennesker (medlemmer), som passer på sig selv og beskytter sig selv ud fra en selvforståelse om at de, ud over at være i/italesætte sig selv som nogen der er i bedring, også er psykisk sårbare.

Dette gjorde sig i særligt omfang gældende i Klub Fontana, hvor de unge som det hedder i medarbejdertermer er "debuterende sindslidende". De er altså ikke i en rehabilitering fra en velkendt tilstand af deres liv; men har derimod netop stiftet bekendtskab med en ny side af sig selv, som de skal lære at have i deres liv. Som en af medarbejderne siger ved en medlems-udviklings-samtale

10 " Alt arbejde $i$ klubhuset er tilrettelagt med henblik på at hjelpe medlemmerne til at genvinde selvverd, selvtillid og en meningsfuld tilværelse" Uddrag af Standard nr. 20 (I: Retningslinjer for klubhuse) 
(MUS) "Hvis du kan få et godt liv med medicinen, så er det jo noget godt for dig. Det er kunsten at lere at leve med det, men det er noget af det, du kan bruge Fontana til" (Lis, medarbejder Klub Fontana).

De unge i Klub Fontana kan meget vel have dårlige erfaringer med voksne og andre mennesker om svigt og sociale nederlag, som gør, at de afviser en antropolog på feltstudier, som grundlæggende 'søger at få noget af dem', mens det de 'får tilbage' tydeligvis er en kortvarig interesse (så ægte den end er), som har en forskningsinteresse (som godt nok har social bevidsthed som afsæt) som baggrund.

De voksne medlemmer i Klubhusene generelt kan lige såvel have erfaringer om svigt og sociale nederlag; men de har længere tids erfaring med deres sindslidelse og kan derfor indgå i forskningsforhold med større 'robusthed'. Men under alle omstændigheder vil man trække på imødekommenhed fra mennesker, som er udsatte eller samfundsmæssigt marginaliserede forstået på den måde, at de i forvejen er sårbare, fordi de befinder sig i sensitive livssituationer og nødig på grund af forskningen skal udsættes for yderligere belastende faktorer (Hvid Jacobsen et al. 2002).

Mødet med 'virkeligheden' - det jeg har kaldt en menneskeligt stille felt, satte sine aftryk på min måde at være der samme med medlemmerne. Jeg opdagede, at jeg var til stede med den mest forsigtige side af mig selv i en etisk bevidst bestræbelse på at være der på medlemmernes måde, med blik for deres præmisser.

Forskerens egen tilgang - for eksempel en lille forsigtighed i det sociale samspil, kan have indflydelse på produktion af empirisk materiale i felten, og jeg gjorde mig mange tanker om min forsigtighed og dermed mine muligheder for at komme tæt 'nok' på. Var jeg berøringsangst, usikker på hvordan jeg skulle 'gå til mennesker med sindslidelse'? Ud fra spontan respons fra medarbejderne om min tilstedeværelse og de to gruppesamtaler med i alt syv medlemmer i Fontæne Huset i Århus, fandt jeg, at min tilgang var hensigtsmæssig.

Men adgang til viden er noget, der forhandles fra øjeblik til øjeblik i en antropologisk feltforskningsproces, så antropologen må hele tiden være opmærksom på de 'ja-er' og 'nej-er' (af sproglig og handlingsmæssig karakter), der gives i situation efter situation efter situation i det hverdagsliv, man gerne vil dele i felten - som er deres klub, arbejdsplads, fællesskab og private liv ${ }^{11}$. Det er at være gensidigt sensitiv og opfatte og efterkomme forskellige typer af afvisninger som medlemmernes beskyttelse af sig selv. Det vil sige, en

${ }^{11}$ Af respekt for deres privathed er medlemmer og medarbejder anonymiseret med opfundne navne. Det kan ses som et problem at man internt ikke vil kunne undgå at kunne identificere hinanden. 
forskningstilstedeværelse så vidt muligt på deres måde med både det, det fortæller og de begrænsninger, det giver for en(hver) undersøgelse.

Så også når medarbejderne siger "Pas på, vi bliver observeret", er det ikke kun at forstå som en 'joke', hvor man som antropolog ses og kan opleve sig som en, der ikke rigtigt 'hører til' (og en der observeres fuldt så meget, som det foregår den modsatte vej) - Det er i lige så høj grad en information om, at ens tilstedeværelse kan medføre oplevelse af usikkerhed.

"Den grundlæggende årsag til at forskning baseret på deltagende observation er
mere problematisk end andre typer forskning, er forskerens nærvær som forsker.
For dem der bliver forsket på, kan problemet formuleres ved, at de fleste mennesker
'do not know how to be studied' og 'what kind of a creature a participant observer
is' (McCall og Simmons 1969:28 [i Wadel 1991:28 AH])" (Wadel 1991:27-8.
Min oversættelse AH)

Det modsvarede jeg med at forsøge at møde deres humor og være åben om mit forehavende, men især ved at søge roller i samspil med medarbejderne, hvor de kunne finde ud af, 'hvem jeg fagligt er' ved at bidrage i drøftelser, der hvor det var muligt. Et forbehold, hvis der er et sådant, i eller fra 'husets' side får betydning for produktion af empirisk materiale, der understøtter forskningsinteressen. Hvis man forstås som fluen på væggen, en observatør der vil 'objektgøre' feltens mennesker, bliver mulighederne for åbenhed og imødekommenhed anderledes, end hvis man får plads til at deltage og bidrage i den mangfoldighed af samspilsmuligheder og aktiviteter der foregår i et Klubhus. Produktion af viden er en gensidig proces mellem subjekter. "I et etnografisk feltarbejde er man helt afhængig af andres accept af ens tilstedeværelse og indvilgelse $i$ at handle og samtale mens man er til stede" (Gulløv \& Højlund 2003:8).

I mødet med mennesker med andre livserfaringer end en selv, bliver det også tydeligt, at man som antropolog må være ydmyg, for nok kan man i almenmenneskelig forstand forstå, hvad det er at føle angst, spændthed, afmagt, lavt selvværd, indre kaos etc. Men man kan ikke gange det de mange gange op og forstå de mentale og kropslige erfaringer indefra, som en sindslidelse indebærer. Man kan kun lytte til det, indleve sig i det og prøve at forstå det - og så forsøge at se den fornemmelse man kan nå frem til, i lyset af det man har lært om samspil i livet i Klubhusene, sådan som det leves. 


\section{Præsentation af feltstudiets Klubhuse - Århus og København}

\section{Fontæne Huset i Århus}

Fontæne Huset i Århus havde 20 års jubilæum i sommeren 2010. Klubhuset i Århus åbnede i maj 1990 og er oprindeligt en gård fra 1887. Det er medarbejderne og medlemmerne selv der restaurerer, ombygger og vedligeholder stedet. Huset er 'længer' om en flisebelagt gårdhave med borde og bænke og blomsterkasser med blomster og krydderurter og et springvand (Fontænen) i midten. Der er drivhus og en opvokset have med terrasser omkring huset.

Fontæne Huset er et etableret Klubhus i Klubhusenes historie i Danmark ikke kun af år, men også i praksis ved, at hverdagen ifølge medarbejdernes udsagn opretholdes af kulturbærere derved, at de internationale retningslinjer i form af nedskrevne standarder om samvær og struktur i hverdagen i Klubhuse verden over, bliver båret af medlemmernes og medarbejderes indgående fælles kendskab til hvad man gør og ikke gør, hvornår og på hvilke tidspunkter i Fontæne Huset. Som en besøgende fra det relativt nye Klubhus i Jelling sagde på et møde på min allerførste feltstudiedag: "Fontæne Huset er en gammel dame, men selv om man er en gammel dame, kan man godt være ung inden i".

'Den gamle dame' præsenterer sig åbenhjertigt. Når man bevæger sig fra trafikknudepunktet på Viby Torv forbi skolen og kirken op ad den stille, blinde villavej Kirketoften, som Fontæne Huset i Århus ligger på, ved man efter få dage, at man nærmer sig en arbejdsplads, et fællesskab, en sikkerhed - måske en helle, og et sted for udfordringer - nogle gange også for personlige kampe.

Men det er alligevel særligt tydeligt, at Fontæne Huset i Århus for den udefrakommende først og fremmest præsenterer sig og fremstår som en arbejdsplads. Rummene signalerer endog meget tydeligt deres funktioner, og menneskene derinde foretager sig de ting, som rummene sender signaler om er relevante. Der er tavler med tydelige beskrivelser af den enkelte Enhed eller lokalitets funktioner, som medlemmer og medarbejdere skal varetage ${ }^{12}$, og der er hele tiden rent og ryddeligt i forhold til rummenes funktion.

12 For eksempel står der på Kontorenhedens tavle vedrørende fredag den 12.marts 2010: "Mødeleder: Jes. Fredag: tømme papirkurve, div. post ud, tjekke dueslag, skrive kommelgå bogen frem, rengøre toilet, printe fremmødeskema. Kl.13 Ugeafslutning. Hver dag: medlemskontakt fødselsdagskort, reception + tavle, email, dagens avis, renskrivning, kopiering, redaktionelle opgaver". 
I Kontorenheden ligger alle skrive- og kontorredskaber på ræd og række i kurven på bordet, papirer ligger i de dertil indrettede bakker eller findes hurtigt i ringbind når nogen spørger efter dem. I Pedelenheden er værktøjet linet op, så det kan findes frem til de forskellige specialopgaver, Enheden løser. På bordet ligger håndværkerblade med information og artikler om det nyeste udstyr, som Enhedens mennesker kan orientere sig i. Der er jernskabe og knager med skiftetøj og opslag med påbegyndte opgaver. I køkkenet er alle redskaber og madvarer organiseret efter type og den mest praktiske og hygiejniske placering, og der er kogebøger og kokkejakker og skjorter i stakke klar til brug.

$\rightarrow$ Mit første møde med min felt var pr. telefon. Jeg skulle aftale mit forbesøg. Kvinden der tog telefonen fortalte, at deres leder sad i møde. Jeg spurgte, om jeg kunne ringe og træffe hende lidt senere. Receptionisten svarede, at mødet ville være færdigt $\mathrm{kl} .15$, og at hun ville skrive mit navn - som hun kunne huske - på en seddel, så deres leder kunne se, at jeg havde ringet og at jeg ville ringe igen $\leftarrow$ (Feltsekvens $\mathrm{FH} \AA$ tirsdag den 2.marts 2010)

I Fontæne Huset i Århus er der seks medarbejdere inklusiv husets leder. De består af tre pædagoger, en værkstedsassistent, en sosu-assistent og en ergoterapeut. Huset har også skiftende studerende i praktikforløb. Mens jeg var på feltstudie i Fontæne Huset, mødte jeg to sosu-elever og en ergoterapeutstuderende. Medarbejdernes faglighed er således forskellig og tværfaglig. Ca. en gang om måneden har medarbejderne supervision med en ekstern supervisor.

Medarbejderne møder klokken 8.00 og tager sig af personfølsomtadministrativt arbejde. Det er det eneste medlemmerne ikke må kende til, og dermed de eneste arbejdsopgaver ud over åbning af post, som ikke varetages på helt lige fod af medlemmer og medarbejdere. Medlemmerne møder senest til fælles kaffe og Morgenmøde, som foregår fra 8.45-9.15. K1. 9.00 er alle til stede. Så gennemgås kalenderen inden alle går ud i deres Enheder. Resten af dagen følger alle Dagsprogrammet med vedvarende vekslen mellem arbejde og pauser.

Fontæne Huset i Århus er normeret til 30 medlemmer. Medlemstallet udgør for tiden (foråret 2010) 27 medlemmer. Heraf er 13 kvinder og 14 mænd. De fleste medlemmer er i en eller anden form for pension; men der er for eksempel også medlemmer, som er der i en arbejdsløshedssammenhæng/med kontanthjælp visiteret til kortere forløb end pensionisternes tidsubegrænsede medlemskab.

Det er karakteristisk, at medlemmerne ikke præsenteres eller præsenterer sig ved deres psykiske problematikker, selv om det er årsagen til, at de arbejder 
i Fontæne Huset og ikke på det 'almindelige' arbejdsmarked. Som en af medarbejderne siger ved et førstegangsbesøg af et muligt kommende medlem, som skal til at fortælle 'noget': "Vi snakker faktisk ikke så meget om diagnoser. Det er vi egentligt ligeglade med her. Vi snakker mere om arbejdet, og hvad vi skal i weekenden og sådan" (Knud, medarbejder FH A).

Selv om medlemmerne er i Fontæne Huset på helt frivillig basis, forventes de at overholde en aftale om at komme og bidrage til husets daglige drift minimum tre men gerne op til fem gange om ugen. Har de forfald er aftalen, at de ringer afbud. Bliver et medlem væk nogle dage (eller hvis et medlem er indlagt), følges en procedure om opfølgning, med for eksempel et telefonopkald fra en medarbejder, hvor nyt fra huset fortælles, medlemmet får at vide, at han/hun er savnet, og medarbejderen hører måske lidt om, hvordan det går.

I forlængelse af Dagsprogrammet med enhedsarbejde og pauser, er der forskellige tilbud så som morgengåtur, ugentlig fitness, rygestop kursus, de studerendes onsdagsaktivitet etc., som medlemmerne kan vælge at deltage i efter ork og interesse. Herudover er der en Jobgruppe, som hjælper med praktik og arbejde, hvis nogle af medlemmerne ønsker hjælp til det. En gang om måneden afholdes jobgruppemiddag for medlemmer, der er ude $\mathrm{i}$ arbejde, så de kan møde hinanden og mødes med medarbejdere og nuværende medlemmer i huset.

I Fontæne Huset i Århus samarbejder medarbejdere og medlemmer om husets drift i tre forskellige Enheder: Det er henholdsvis Kontorenheden, Pedelenheden og Køkkenenheden. Organiseringen i disse Enheder (med arbejdsfordeling og samarbejdsrelationer) indgår i hele Fontæne Husets overordnede organisering med fælles pauser, fælles møder, udvalgsmøder og tværgående fælles arbejdsopgaver. Medlemmer og medarbejdere fungerer således i husets organisering på flere planer og på flere måder - med fagspecifikke opgaver tilhørende den enkelte Enhed og med opgaver knyttet til huset som helhed. Det store demokratiske forum er onsdagens Husmøde, hvor alle stemmer høres. Men på enhedsmøderne kl. 9.15 drøftes også holdninger til 'diverse' som bringes med til de rette fora. Herudover holder hver Enhed en årlig enhedsdag, hvor alt det der rører sig i Enheden er til potentiel evaluering.

Organiseringen giver den enkelte mulighed for at involvere sig på mange planer. Konkret betyder det, at nogle medlemmer øver sig i at møde om morgenen og løse det, de nu kan afhængigt af 'dagsform'. De har deres dagligdag helt 'nært' tilknyttet Fontæne Huset på Kirketoften. Nogle medlemmer er mere udadvendte og deltager sammen med medarbejderne i at byde nye medlemmer velkomne i førstegangs-besøg med rundvisninger i huset. Andre medlemmer er med i både det daglige arbejde $i$ huset og i nationalt samarbejde. Det er for eksempel at afholde og/eller deltage i kurser i Klubhusene rundt omkring i landet (dansk-træning), eller 
landsmødeorganisering og deltagelse heri. Atter andre bevæger sig ud på det internationale plan og deltager i kurser, træning og konferencer i udlandet. De taler med begejstring i stemmen om besøg og ophold i Klubhuse i USA eller konferencer rundt omkring i Europa.

At Fontæne Huset, på Kirketoften, oppe ad bakken, lidt væk fra trafikknudepunktet Viby Torv i Århus, er del af noget meget større er under alle omstændigheder uundgåeligt i alles bevidsthed i dagligdagen. Dels er der nyheder fra andre huse på Husmødet (planer om nye huse i Danmark), dels kommer der (og hænger) nyhedsbreve fra andre Klubhuse i verden til fri læsning, dels er der, lige mens jeg er på feltstudier, mail-korrespondance på engelsk med Fountain House New York, der hvor det hele startede, som nogle af medlemmerne og medarbejderne har besøgt, og hvorfra man venter besøg i nærmeste fremtid.

Selv om mange medlemmer i Fontæne Huset er udredte - er pensionister og dermed uproblematisk kan komme og blive medlemmer af Fontæne Huset, og ikke nødvendigvis har 'et almindeligt arbejde' som mål, understreges det for nytilkomne, så som antropologen, at Fontæne Huset i Århus ikke er et værested. Det er et dagsprogramorganiseret fællesskab. "Det kan nok skræmme nogen væk, men vi fastholder det altså alligevel" (Minna, medarbejder FH $\AA$ ).

I Fontæne Huset er alle hinandens kolleger. I min første præsentation af huset fortalte lederen mig, "Jeg oplever ikke, at jeg er leder, og så er der nogle andre, der er medlemmer - de er mine kolleger alle sammen - på forskellige måder er medarbejderne og medlemmerne mine kolleger". Ligeværdigheden viser sig også når man spørger 'hvem er yngst og hvem er ældst'. Så skelnes der ikke mellem medlemmer og medarbejdere. "Det strækker sig nok fra midt eller sidst $i$ tyverne for den yngste til midt $i$ halvtredserne for den xldste" bliver en medarbejder og et medlem enige om, som dækkende svar på mit spørgsmål.

Fontæne Huset i Århus er del af kommunes psykiatri og dermed også Århus Kommunes økonomi og drift. Det giver høj grad af samarbejde med psykiatrien i kommunen. Blandt andet arbejder hele psykiatrien med en 'CARe/recoverytilgang' i arbejdet, som Fontæne Husets medarbejdere har uddannelse i - og det forpligter også Fontæne Huset til at arbejder med, hvordan dette står i forhold til Klubhusmodellen. Fontæne Huset drives jf.\$104 i Lov om Social Service $^{13}$.

\footnotetext{
${ }^{13}$ Bekendtgørelse af lov om Social service. I Kap. 19 vejledning nr. 95 til Lov om Social service punkt 233 hedder det: "... tilbud til personer med særlige sociale problemer [vil AH] ofte [vil] være tilbud uden visitation. I mange aktivitets- og samværstilbud tilrettelægges aktiviteter af sundhedsfremmende karakter, støtte til at komme i beskxftigelse og aktiviteter med et idrætsmæssigt indhold. Aktivitets- og samvarstilbud tilbydes i praksis under mange betegnelser, hvor varesteder, sociale caféer, varmestuer, daghjem, klubber, Fountain House er nogle af de almindeligste..." (min fremhævelse $\mathrm{AH})$.
} 


\section{Fountain House København (Kontorenheden)}

Fountain House København ligger på Østerbro. Man kan komme dertil fra alle sider. Jeg bevæger mig de få gader fra Vibenshus Runddel omkring et par hjørner til Teglværksgade, som vejen hedder. Fountain House København præsenterer sig fra min ankomstside som en lys 'kasse' bag en busk og med fyldte cykelstativer uden for. Fountain House fysiske omgivelser er etagebyggeri. Flere med tydelig skiltning om, at der indenfor foregår aktiviteter med job- og kompetenceudviklende fokus.

Indgangen til Fountain House har det karakteristiske springsvandslogo på glasdøren. Fountain House i København er fra slutningen af 1986 og dermed det ældste Klubhus i Danmark. Nogle medlemmer har været der så længe, at de kan huske 'de gode gamle dage', for de taler med drømmende stemme og fjernt blik, om dengang huset lå på Sortedam Dosseringen - før det blev stort.

Stort er det med sine fem forskudte planer inden- og udendørs. Et helt sneglehus - med terrasser i niveauer mellem bygningerne som omringer Springvandet (Fontænen) i midten af gården - i den gamle skorsten. For der har tidligere været fabrik. Men der er delte meninger om hvilken fabrik, alt efter hvem man taler med. Nogle mener bolsjefabrik, mens andre taler om saftfabrik. Alle har en historie om husets fortid. Der fortælles også gerne om husets fortid som 'Weekendsex'; men det er udbredt, at det i virkeligheden er en vandrerhistorie, som alle gerne fortæller, men få præcist tror rigtigt på.

Udenpå ser Fountain House stille ud, men når man kommer ind, er der straks masser af klare farver, lysindfald og mennesker der hilser og smiler. "Godmorgen" eller "Velkommen" lyder det med det samme til alle, der træder ind. Nogle svarer, mens andre haster forbi op i Enheden. "Jeg svarer ikke godmorgen, hvis jeg kommer for sent, for så har jeg dårlig samvittighed" (Harald, medlem FH K). Man træder altså direkte ind i receptionen, hvorfra man vises til det sted og de mennesker, man efterspørger. Sådan var mit første møde med Fountain House København også.

$\rightarrow$ Det er første møde med felten. Vi skal møde på forbesøg klokken 11. Vi bliver budt velkommen i Receptionen. Receptionisten ved straks, hvem vi er og viser os gennem en masse gange op og hen og ned og op igen før vi træder ind i Kantinen. Vi får udpeget en plads i udkanten af fællesskabet. Lederen holder oplæg og rundt om ham ved Kantinens borde sidder medlemmer og medarbejdere og afkræver svar på deres spørgsmål. Lidt efter er de færdige med deres dagsordenpunkter, og vi bliver bedt om at præsentere os $\leftarrow$ (Feltsekvens FH K torsdag den 25.marts 2010)

For den udefrakommende er fornemmelsen er at træde ind i et klubhus. Der er lyde af mennesker, der snakker og ler, der går nogen rundt, og der ligger aviser 
og brochurer 'overalt', man møder lyse og sprælske farver på væggene, sommerfugle malet på væggene, åbne og lukkede døre, trapper, kopimaskine, en indbygget garage med bil, vaskeri, terrasser, fyldte opslagstavler, løbesedler om for eksempel 'Livslinjen' spredt på bordene, fotos og farverige malerier på væggene, bakker med mulighed for kaffe køb, og ting folk har lagt fra sig. "Man kan godt regne med, at hois man lægger noget fra sig, så ligger det her, når man skal bruge det igen - der er aldrig noget her i huset, som er blevet flyttet" (Gunner, medlem FH K).

Inde i den enkelte Enhed mødes man af orden udtrykt $\mathrm{i}$ et velorganiseret kaos af relevante 'ting og sager', som mennesker bruger til de aktiviteter, lokaliteten er beregnet til. I Kontoret, hvor jeg fortrinsvis havde min gang, er der skriveborde, computere, whiteboardtavle med dagens opgaver ${ }^{14}$ og ophængte 'skuffesystemer' med presserende, kommende og afsluttede opgaver. På det store møde-bord centralt i rummet ligger masser af papirer som viser, at nogen har noget i gang. Der ligger også en medlems-fremmødeliste, hvor medlemmerne krydser sig ind. Nogle gange af sig selv, andre gange huskes de på det af en medarbejder. En dag står der en brugt tallerken i vindueskarmen. Det kommenteres af alle, 'hvad den dog gør her'.

På endevæggen modsat whiteboardtavlen hænger to ure: et der viser hvad klokken er i Fountain House København, og et der viser, hvad klokken er i Fountain House New York. Det nationale og internationale islæt er til stede. Mens jeg er på feltstudier rejser en medarbejder til New York, og en anden bliver udlånt til et Klubhus i Norge. Der tales om det kommende store Landsmøde, for det er tilmeldingstidspunkt, og nogle fortæller om besøg, de har været på i andre huse i Danmark. Men fokus er på væren i huset og arbejdet i Enheden. Der er mange nye og relativt nye medlemmer, som lige er ved at finde sig til rette helt lokalt i Fountain House København.

Der er mange medlemmer i Fountain House som helhed. Det ses til frokost, hvor den store kantine nogle dage er helt fuld, mens der andre dage er færre fyldte borde. Men Fountain House København har også tre forskelligartede målgrupper, de skal imødekomme og tilvirke Fountain House modellen til. Det er henholdsvis studerende med psykisk sårbarhed i Bogstøtten, unge med psykisk sårbarhed (ml. 18 og 25 år) i Klub Fontana ${ }^{15}$, og voksne sindslidende i Fountain House 'kernehus', som det benævnes, fordelt i

14 På tavlen for mandag den 12. april 2010 står der: "Mandag Kontor: bestille kontorartikler, oprydning $i$ skabe, fødselsdagskort, købe buket. Reception: passe telefon, post ind/ud, aflevere kopper, almindelig oprydning, tjekke mail, tjekke dueslag, lave regnskab. Rengøring: rengøre toiletter, støvsuge, vaske gulv, rengøre flader, feje bagtrappe".

${ }^{15}$ Det var del af den antropologiske del af projektet at undersøge samspil i Klub Fontana. Præsentation af Klub Fontana og feltberetning herfra kan læses særskilt nedenfor. 
fire Enheder: Kontorenheden, Køkkenenheden, Serviceenheden og Jobgruppeenheden. Mit feltstudie i 'kernehuset' fandt sted i Kontoret ${ }^{16}$.

Der er to medarbejdere i kontoret (af i alt 19 inklusiv ledelse i hele Fountain House). Det anses som et fællesfagligt udgangspunkt, at medarbejderne har brede kompetencer, der gør, at de til støtte for medlemmerne kan tage ansvar for driften i en hvilken som helst Enhed, samtidig med at de gerne må have særlige kompetencer rettet mod den Enhed, de specifikt er ansat i. Men "Alle medarbejdere skal kunne tage den gode samtale" (Gudrun, medarbejder FH K). De fleste medarbejdere i Fountain House har uddannelse i Proces Inquiry. Men det er forskelligt fra Enhed til Enhed, hvor metode tæt der arbejdes hermed.

Medarbejderne i Kontorenheden har faglige baggrunde fra henholdsvis psykiatrien og universitetet og afspejler således tværfagligheden i resten af huset. Medarbejderne møder klokken 8.30 og laver enheds-administrativt arbejde indtil Morgenmødet i Cafeen klokken 8.50. Her gennemgås dagens kalender og hvis der er koordineringsopgaver så som brug for hjælp i en Enhed, aftales en løsning her. Det er mest medarbejdere, der kommer til Morgenmødet, fortælles det, og efterhånden kan jeg godt se, at der kun er et par medlemmer til stede hver dag. Men der er plads til alle. Således er der respektfuldt ophold i kalenderoplæsningen og smil en dag, da et par af de unge fra Klub Fontana er der: "Hvor var du henne før, da jeg kom?"; "Nede med mit tøj"; "Nåa, jeg har heller aldrig været her så tidligt før. Det må være historisk".

Efter mødet går alle hver til sit og medarbejderne gør Enheden klar til enhedsmødet kl.10. Eller snakker med allerede fremmødte medlemmer og understøtter det arbejde, de er gået i gang med (pasning af reception, forsendelser mv.).

Medlemmerne skal helst møde før kl. 10 eller før kl.13, så de er med til et (eller begge) af de daglige enhedsmøder. For her fordeles dagens arbejdsopgaver og man taler kort om 'hvordan det går' i Kontoret og måske personligt. En gang om ugen holder Enheden et Udvidet Enhedsmøde med dagsorden, ordstyrer og referent.

Men i Kontoret er mange af medlemmerne nye eller relativt nye, og derfor er de ikke inde i strukturen endnu. De nye opfordres til at øve sig på at være der til enhedsmødet starter. Det ses også, at nogle medlemmer er i gang med opgaver, som de ikke blev færdige med, sidst de var der, så de møder heller ikke altid til enhedsmødet. Nogle få medlemmer møder helt stabilt og

${ }_{16}$ For at skærpe mit blik for Klubhuspraksis generelt og forstyrre igangværende analyser, besøgte jeg under feltstudiet kortvarigt Køkkenenheden og Bogstøtten. Jeg talte også med medlemmer og medarbejdere fra de andre Enheder i pauser/frokost og på vej til og fra feltarbejde. 
understøtter således sammen med medarbejderne Dagsprogrammet indlejret i modellen.

Efter de to enhedsmøder er dagen organiseret efter Klubhusmodellen med vekslen mellem arbejde og pauser. Medlemmerne mindes om pauserne af medarbejderne eller andre medlemmer, men vælger eller fravælger selv efter lyst og behov hvordan de indgår. Nogle går i Cafeen og drikker kaffe, andre henter en kop med ned og arbejder videre, atter andre holder slet ikke pause. Som Oda (medlem FH K) siger "Uh, nej pause, det kan jeg slet ikke finde ud af. Jeg bliver her, og jeg er også i gang med mapperne". Det forholder sig lige så til frokost $\mathrm{i}$ Kantinen, som Køkkenenheden står for. "Jeg går hjem nu, for jeg kan ikke spise sammen med andre mennesker, efter jeg blev syg; men jeg tænker på at komme $i$ Fountain House to formiddage om ugen i fremtiden" fortæller Olga (medlem FH K).

Jeg møder omkring 15 af medlemmerne i Kontoret, mens jeg er på feltstudier (der er på feltarbejdstidspunktet 33 aktive medlemmer i Kontoret fordelt på 16 mænd og 17 kvinder). Medlemmerne har individuelle aftaler om, hvor mange gange om ugen de kommer. Det er mellem en dag om ugen til alle ugens dage. Har de forfald, er aftalen, at de ringer afbud. Hvis et medlem er fraværende i længere tid, tager medarbejderne kontakt og hører, hvordan det står til, og hvornår medlemmet, som er savnet, påtænker at komme igen.

I forlængelse af Dagsprogrammet har medlemmerne mulighed for at vælge at deltage i aktiviteter på tværs af huset. Det er de store fællesmøder om torsdagen: Modelmøder (hvor Fountain House modellen er på programmet) eller Husmøder med aktuelle punkter på dagsorden. Det er de store 'demokratiske organer', hvor alle stemmer søges hørt. Men i Enhederne drøftes også mange emner, så holdninger afdækkes, som medlemmer og medarbejdere bringer videre i udvalg og ad hoc mødesammenhæng. Der er også aktivitetstiltag $\mathrm{i}$ form af en ugentlig håndarbejdsgruppe som er et medlemsinitiativ, og Klubaftner hvor aktuelle emner tages op. Endvidere er der fitnesstilbud.

Fountain House i København er en Selvejende Institution for borgere i Københavns Kommune med psykisk sygdom eller alvorlig psykisk sårbarhed. Det drives jf.§104 i Lov om Social Service ${ }^{17}$.

\footnotetext{
${ }^{17}$ Bekendtgørelse af lov om Social service. I Kap. 19 vejledning nr. 95 til Lov om Social service punkt 233 hedder det: "... tilbud til personer med særlige sociale problemer [vil AH] ofte [vil] være tilbud uden visitation. I mange aktivitets- og samværstilbud tilrettelægges aktiviteter af sundhedsfremmende karakter, støtte til at komme i beskxftigelse og aktiviteter med et idrætsmæssigt indhold. Aktivitets- og samvarstilbud tilbydes i praksis under mange betegnelser, hoor varesteder, sociale caféer, varmestuer, daghjem, klubber, Fountain House er nogle af de almindeligste..." (min fremhævelse $\mathrm{AH})$.
} 


\section{The Fountain House Way}

- En feltberetning om medlemskab fra Fontæne Huset i Århus og Fountain House København

\section{Introduktion}

I den antropologiske del af undersøgelsen vedrører interessen medlemmernes og medarbejdernes samspil og dermed deres fortolkninger i ord og handling af Klubhusenes muligheder. Det drejer sig altså om, hvad der er på spil i praksis i Fontæne Klubhuse som ramme om og social sammenhæng for medlemmernes rehabilitering ${ }^{18}$.

Medlemskab er en social kategori, fordi interessen vedrører det at være medlem, som medlemskab gøres i samspil med klubhusmodellen som den leves i de lokale Klubhuse og i samspil med det at være klubhusmedarbejder. Feltberetningen er delt op i to delafsnit og en afsluttende analyse.

I del 1 drejer det sig om medlemskabets forpligtede karakter. Kategorien forpligtet er valgt, fordi ordet henviser til handling bundet til noget ekspliciteret såvel som til noget der ikke nødvendigvis italesættes, samtidig har ordet også en ansvarsbetydning ${ }^{19}$. Disse tre betydninger om Klubhusmodellen der er der før medlemmerne træder ind i husene, som de må sige 'ja' til, når de bliver medlemmer, omgangsformerne der reproducerer modellen i levet hverdagsliv, og at medlemmerne påtager sig at arbejde med deres rehabilitering inde $\mathrm{i}$ rammen Fontæne Klubhus, er alle del af min analyse af, hvordan medlemmerne gør medlemskab i Klubhusene ${ }^{20}$.

\footnotetext{
18 " Alt arbejde i klubhuset er tilrettelagt med henblik på at hjælpe medlemmerne til at genvinde selvvard, selvtillid og en meningsfuld tilværelse ...") (uddrag af Standard nr.19 I: Retningslinjer for klubhuse).

${ }^{19}$ www.ordnet.dk

${ }^{20}$ Når jeg ikke bruger ordet forpligtende, er det for at understrege, at medlemskab er frivilligt og det at indgå i samspil om efterlevelse og reproduktion af modellen, som den leves og tolkes lokalt i de enkelte Klubhuse ikke virker som noget, der er båret oppe af tvang og uønsket kontrol. Til gengæld er medlemskab heller ikke u-forpligtende, hvormed det er noget for nogen. Det er den kompleksitet, jeg prøver at indfange med kategorien om, at medlemskab har en forpligtet karakter.
} 
I del 2 ser jeg nærmere på hvordan der udleves medlemskaber, via kontinuitet i fællesskabet hvor medlemmerne og medarbejderne sammen er bærere af den arbejdsstrukturerede dag, og via medarbejdernes måder at træde i karakter som medarbejdere, der støtter og er kolleger med medlemmerne.

For medlemskab er ikke en færdig størrelse, der sker med indtræden alene og med indehavelse af medlemskort. Medlemskab er en proces, som medlemmer i samspil med medarbejdere lever i Klubhusene.

Til slut, under overskriften The Fountain House Way, analyserer jeg på baggrund af den hidtidige analyse, at modellens fokus på rehabilitering med det individuelle medlem i centrum står i nært forhold til modellens fokus på fællesskab og samarbejde, når blikket er rettet mod samspil mellem medarbejdere og medlemmer. Der er altså ikke er noget modsætningsforhold i hverdagslivet i Klubhusene mellem individuel rehabilitering og fællesskabets bedste.

\section{Del 1. Medlemskab har en forpligtet karakter - om arbejdsmotiverethed og klar-hed}

I samspillet mellem medarbejdere og medlemmer er der retningslinjer for tilstedeværelse og omgangsformer. Det er dels levede retningslinjer, forstået på den måde, at de bliver synlige fordi de udvirkes i det daglige samspil af medlemmerne og medarbejderne. Som levede, ser retningslinjerne ud til at bevirke, at medlemmerne fremtræder som medlemmer, der hører til i Klubhusene. Dels er der Jf. klubhusstandarderne også nedskrevne retningslinjer for tilstedeværelse og omgangsformer i Klubhusene ${ }^{21}$.

Medlemskab har således en forpligtet karakter både fordi stederne som Fontæne Klubhuse helt overordnet fungerer på bestemte måder og efter bestemte retningslinjer (der tales for eksempel om grænser for kompromisser for vedvarende at kunne kalde sig et Klubhus), og fordi der er forpligtetheder, der bliver tydelige qua samspillet mellem medarbejdere og medlemmerne i hverdagen inde i husene. "Fontæne Huset er ligesom en fodboldbane, og når man træder ind på en fodboldbane, gør man sig detaljerne klart om, hvad det er at være $i$ den ramme. Her i Fontæne Huset er det forudsigelighed og kontinuitet, men uden at det bliver kedeligt. Hver dag er en fest - og det er fordi, der er nogle at spille sammen med. En sammenhæng med retningslinjer", illustrerer Betty (medarbejder FH Å).

Fodboldbanen, eller Klubhuset, stiller bestemte forventninger om at spillerne, eller medlemmerne og medarbejderne, foretager sig bestemte aktiviteter og efterlever bestemte omgangsformer. Det er retningslinjer, der er

${ }^{21}$ Feltstudiedelen evaluerer ikke praksis i forhold til de 36 Klubhusstandarder, men inddrager dem som kontekst til forståelse af den sociale sammenhæng, når det er relevant. 
der på forhånd, som bestemmer noget om 'spillets gang', og hvordan det foregår.

Men det er medlemmerne og medarbejderne inde i Klubhusene, som skal spille sammen og tilsammen udgøre den sociale sammenhæng med de muligheder, det giver. Det giver sig udtryk som forudsigelighed og kontinuitet $i$ et Fontæne Klubhus samtidig med, at "Standarderne er levende, altså de kan diskuteres og bliver det. Det er ikke sådan nogen regler, der kommer ovenfra Annemarie, hvis du tror det. Det er altså noget, vi diskuterer, om de er relevante lige her" (Gertrud, medlem FH Å). Jeg forstår Gertrud sådan, at hun peger på, at medlemmerne oplever, at der er noget yde et bidrag til, noget at tage stilling og forholde sig til på egne og husets vegne - ikke alene noget at efterleve.

Der er også en forpligtethed i spil i Klubhusene om at 'være klar'. At være klar markeres af både medlemmer og medarbejdere som en faktor ved medlemskab. Det kommer jeg tilbage til.

Afsættet til at jeg har benævnt medlemskab ved en forpligtethed har udgangspunkt i min analyse af feltnoter og erfaringer fra Fontæne Huset i Århus. Medlemmerne der har, for langt de flestes vedkommende, lange medlemskaber bag sig og sammenlignes i en diskussion mellem medarbejdere og medlemmer i en kaffepause, med det langsomme vand i en bæk. Det med lav gennemstrømningshastighed. "Vi har næsten ikke nogen med den hurtige gennemstrømning - måske to lige nu. Men vi kunne sagtens bære det. Fordi vi har de stabile, kan vi sagtens bære mere af det andet", forklarer Betty (medarbejder FH Å) om metaforens relevans i forhold til medlemsgruppen, sådan som den ser ud i øjeblikket.

Som det langsomme vand i bækken er medlemmerne, sammen med medarbejderne, særligt tydelige som bærere af kontinuitet i hverdagslivet. Det gør det muligt for en udefrakommende at gøre sig greb om noget af det, der ligger i medlemskab af Fontæne Klubhuse. Og via feltstudierne i Fountain House København, hvor gennemstrømningen næsten kan siges at være 'modsat' med mange medlemmer på hurtig gennemstrømning i huset ${ }^{22}$ og mange nytilkomne i den Enhed, hvor jeg bedrev mine feltstudier, blev det muligt bedre at forstå medlemmernes arbejde med et forpligtet medlemskab, som ingenlunde er en 'færdig' tilstand.

\section{Medlemmets arbejdsmotiverethed}

Det første jeg vil pege på i analysen af medlemskab som forpligtet størrelse, er klubhusmodellen som den udtrykker sig i hverdagens samspil mellem

${ }^{22}$ Mange af de medlemmer jeg talte med var i gang med at søge videre i flexjob, skånejob, praktikker mv. 
medarbejdere og medlemmer ${ }^{23}$. Analysen viser, at via Klubhusmodellen som den fungerer omsat til praksis i Klubhusene, er der det udgangspunkt for medlemskab, at det enkelte medlem må være arbejdsmotiveret.

For det at udleve sit medlemskab ved sin arbejdsmotiverethed giver vedvarende adgang til huset og til indre deltagelsestilhør i huset. Dermed opfylder medlemmet det, Klubhusene indbyder til fysisk og organisatorisk. I gruppesamtalen forklarer August (medlem FH Å), at "Det kræver det her hus også af mig, at jeg kommer og bruger noget af min arbejdsevne. Altså, man kan ikke bare sidde og drikke kaffe. På den måde skal man yde noget for at være her"(G 1.6.2010).

Når medlemmerne yder noget, som August siger, udlever de deres arbejdsmotiverethed. For på den måde viser de sig og fremstår i fællesskabet med de andre medlemmer og medarbejdere som nogen, der er arbejdsmotiverede.

$\rightarrow$ Filippa (M) ${ }^{24}$ søger efter en arbejdsopgave. På grund af forsinkelse til morgen og derefter besøg i Enheden af sosu-elever fra 'Sankt Hans', nåede hun ikke at deltage i opgavefordelingen på enhedsmødet. Hun kigger i de opmærkede plasticholdere på væggen, mens hun fortæller mig, at hun plejer at finde referater til renskrift der. Men der er ingen referater i dag. Hun kigger også på tavlen med nedskrevne opgaver, men hun finder tilsyneladende heller ikke en opgave der. Så spørger hun Bjørn (M), som sidder og arbejder ved et af skrivebordene, om han har kendskab til en opgave, hun kan gå i gang med. Bjørn spørger Frans (MA), som netop kommer ind på Kontoret. "Ja, er du tosset Filippa, der er opgaver " siger Frans. Filippa: "Til mig? Noget jeg kan lære?". Frans bekræfter; men han har lige noget, han skal gøre færdigt med et andet medlem ... Frans kommer tilbage og siger, at der er en helt ny opgave, der skal laves, men at den i det hele taget skal udtænkes. Det vil Filippa gerne arbejde med. Hun stiller et par uddybende spørgsmål og får svar. Da det på et tidspunkt bliver for svært, sætter de sig sammen og laver en skitse, som Filippa arbejder videre ud fra. De aftaler, at hun skal kalde, før hun printer, så de lige kan se på resultatet. "Fantastisk, jeg vidste du kunne Filippa", roser Frans, da opgaven er helt fuldført. Et par dage efter tages det regneark Filippa har konstrueret i brug af nogle andre medlemmer $\leftarrow$ (Feltsekvens Kontoret FH K onsdag den 14.april 2010)

\footnotetext{
${ }^{23}$ Som jeg har beskrevet i præsentationerne af Klubhusene, fremtræder klubhusmodellen også via husenes indre fysiske udtryk som indretninger, der signalerer mulighed for bestemte aktiviteter.

${ }^{24}$ Medlemmer præsenteres første gang de nævnes i det enkelte feltuddrag med (M) efter deres navn (anonymiseret), medarbejdere præsenteres første gang de nævnes i det enkelte feltuddrag med (MA) efter deres navn (anonymiseret).
} 
Arbejdsmotiveretheden kommer til udtryk i samspillet, hvor medlemmet på baggrund af sin motivation for at bidrage i Klubhusets drift inddrager sig (søger, spørger og begejstres over opgaver). Det gør hun i samspil med et andet medlem og sammen med medarbejderen, som dermed bliver inddraget i hendes udlevelse af medlemskab, på en måde så hendes arbejdsmotivation med den nødvendige støtte får 'ben at gå på'. Og hendes arbejdsmotiverethed har konsekvenser, for produktet af hendes brug af sin arbejdsevne kommer andre til gode, da de senere på ugen har brug for hendes skema. Hun har tydeligvis bidraget med noget nyttigt til Enhedens drift.

Medlemmerne skal, med vide rammer for hvad det er i praksis, ville - og (med eventuel støtte) kunne indgå i modellens arbejdsstrukturerede dag (Dagsprogrammet) ${ }^{25}$. Som August udtrykte det, skal man komme og yde noget, men han understreger også, at det er den enkeltes sag, hvor meget man påtager sig: "Man bestemmer selv, hvor meget man vil udfordres her. Man kan bare holde sig $i$ periferien eller gå ind $i$ stormen, hvis man vil - Det bliver accepteret, hvad man vil og ikke vil" (August medlem FH Å). Gertrud (medlem FH Å) har en lignende erfaring om tilpas udfordring, som noget hvert enkelt medlem individuelt tager bestemmelse om i forhold til sin egen arbejdsevne: "Det er en balance man må finde, mellem at involvere sig $i$ det man synes er spændende, men ikke mere end man kan overkomme".

En medarbejder i Fontæne Huset i Århus fortæller, at de er vedholdende i organiseringen af dagen i det strukturerede Dagsprogram, selv om "Det kan nok skræmme nogen væk, men vi fastholder det altså alligevel"(Minna, medarbejder FH A).

Man kan sige, at menneskene i Klubhusene i grundholdning og via deres praksis tager afstand fra at være 'væresteder' eller 'behandlingssteder' med de medlems- og medarbejderpositioner det ville indebære, og at livet i Klubhusene indebærer at være del af og prioritere at være del af noget, der er anderledes end på et værested eller et behandlingssted.

"Jeg kan godt lide papir-nusseriet og atmosfxren, og hois der er en, der siger, 'Kan du lige lave det?', så siger jeg 'Nej, det kan jeg ikke endnu, men jeg arbejder med at komme til at kunne'", forklarer Filippa (medlem FH K). Dermed gør hun sin arbejdsmotiverethed tydelig for omgivelserne, tilsat sin viden om sin

25 'Den arbejdsstrukturerede dag' er modellens ord for Dagsprogrammet med standarderne 1520, som vedrører, hvordan medlemmer og medarbejdere indgår i klubhusets daglige driftsopgaver således, at der ved en bevidst lav normering af medarbejdere sikres en grundlæggende ligeværdighed i og med den enkeltes nødvendige deltagelse: "Dagsprogrammet svarer tidsmæssigt til en typisk arbejdsdag ... Klubhuset er organiseret $i$ en eller flere arbejdsenheder, som hver især har en tilstrækkelig medarbejderstab, antal medlemmer samt meningsfyldte arbejdsopgaver til at opretholde en hel og engagerende arbejdsdag" Uddrag af Standard nr. 17 \& 18 (I: Retningslinjer for klubhuse). 
nuværende arbejdsevnes grænser, som ved siden af at udfylde sin plads i Enhedens drift er det hun arbejder med.

"Der er en del mennesker, der har lyst til at blive parkeret på en pension, men sådan har jeg det ikke. Jeg vil ikke være på et dagcenter $i 20$ år, sådan som ham [en kammerat AH], det er derfor, jeg er i Fontæne Huset. Jeg ved godt, jeg ikke kommer $i$ 'rigtigt' arbejde $i$ min alder', forklarer August (medlem FH Å) en medarbejder om, hvorfor han har haft en voldsom diskussion med en bofælle aftenen forinden. Medarbejderen svarer: "Nej, måske ikke, men du kan med sindsro sige, at du kommer her og gør dit arbejde "(Anker, medarbejder FH Å). Dermed udtrykkes oplevelsen af, at medlemmet bruger sin arbejdsevne i Fontæne Huset. Sådan som han gerne vil, og som huset fordrer af ham. "Da jeg startede, var det ikke så godt. Altså, det var måske mere humøret, der ikke var så godt. Intensiteten var ikke så god. Men det kom sådan efterhånden ... så gik tiden, og så blev det bedre" (Jes, medlem FH Å). Bjarne (medlem FH Å) svarer: "Jamen Jes, du har også - jeg synes, du har fået en høj arbejdsevne $n u^{\prime \prime}(\mathrm{G} 1.6 .2010)$.

Arbejdsmotivationen hænger meningsfuldt sammen med arbejdsorganiseringen - altså at Klubhusene er arbejdsfællesskaber organiseret ved Dagsprogrammet. Bjørns (medlem FH K) overvejelse om Klubhusets formål med at være arbejdsorganiseret, set fra sin brede og lange erfaringsbaggrund med Fountain House muligheder, vedrører netop, hvorfor det er væsentligt at vægte/fastholde krav om arbejdsmotivation overfor mennesker med sindslidelse eller psykisk sårbarhed: "Det er en fejl, hois man tror, at psykisk syge ikke kan klare så meget - Altså, så kan de ikke, hois man tror det. Men hvis man tror, de kan, så kan de også".

Man kan sige, at Bjørn understreger præcist det (om arbejdsmotivationen til enhedsarbejdet og det sociale), som klubhusmodellen har som eksakt udgangspunkt: At de kan ${ }^{26}$ - hvis det altså er med det udgangspunkt de mødes, og hvis de (er klar til) på deres individuelle måde at udleve den tankegang. "Jeg var vel social analfabet, da jeg kom. Jeg stod bare i køkkenet og passede mit; men så var der var en medarbejder, der så, at jeg godt kunne", siger Bjørn om sit forløbs udgangspunkt, hvor støtte fra en medarbejder var god hjælp for ham til at få rigtig gang $\mathrm{i}$ at udleve den motivation, han ankom til huset med.

Asta (medlem FH Å) forklarer: "Jeg har brugt det der 'Jeg er psykisk syg, jeg kan ingenting'. Og der hvor jeg var dengang, gjorde personalet den største fejl: De føjede mig".

Man kan sige, at medlemmerne formidler erfaringer gjort i Klubhusene med faktisk at have noget fagligt og socialt at byde ind med, der er nyttige i et fællesskab med andre og på den arbejdsplads et Klubhus er. Og at det de kan

26 "Dagsprogrammet inddrager medlemmer og medarbejdere sammen i klubhusets drift. Klubhuset fokuserer på medlemmernes stærke sider, evner og fardigheder." Uddrag af Standard nr. 15 (I: Retningslinjer for klubhuse). 
fagligt og socialt kommer til udtryk som ressourcer ved deres deltagelse i Dagsprogrammet, - altså via modellens organisering af fællesskab og invitation af deres forskellige arbejdsevne, som arbejdsevnen kan udleves i hverdagslivet $\mathrm{i}$ Klubhuset.

Men det er vigtigt at forstå, at medlemmernes arbejdsmotivation ikke må være 'for meget' eller kan stå alene. Den arbejdsstrukturerede dag og dermed arbejdsmotivationen er præcist ikke kun den enkeltes arbejdsopgaver knyttet til Enheden. Den arbejdsstrukturerede dag består i høj grad i samarbejde og i en nøje vekselvirkning mellem arbejdsmæssig og social (genop)træning."Nej, han var her ikke ret længe. Han ville arbejde, men han ville ikke holde pause og deltage $i$ pauserne. Så havde han ikke lyst til at vare her, kan man sige, for det hører med, at her er både enhedsarbejdet og det sociale i pauserne" siger Anker (medarbejder FH Å) i en snak med et medlem om, hvor et tidligere medlem egentligt blev af.

Andreas (medlem FH ^) gør følgende status i gruppesamtalen: "Man skal være forberedt på at lave noget, arbejde lidt og så skal man være forberedt på at være social også ... det kræver nogle sociale færdigheder at være $i$ sådan et hus og have nogle forhold til mange mennesker. Der er jo pauser og fordelingsmøder, hvor man også løber ind $i$ de andre"(G 4.6.2010).

Inde i Enheden bærer for eksempel den måde enhedsmødet bliver brugt af medlemmer og medarbejdere den 'indre arbejdsstrukturering' med fordeling af dagens opgaver.

\begin{tabular}{|c|c|}
\hline $\begin{array}{l}\text { A. Enhedsmøde med medarbejderen } \\
\text { som støtte til medlemmets } \\
\text { arbejdsmotivation }\end{array}$ & $\begin{array}{l}\text { nitiativtager til udvirkning af } \\
\text { rbejdsmotivation }\end{array}$ \\
\hline $\begin{array}{l}\rightarrow \text { Der er morgen-enhedsmøde i } \\
\text { Kontoret. Frans (MA) afholder mødet. } \\
\text { Vi sidder omkring det ovale bord } \\
\text { foran whiteboardtavlen, hvor dagens } \\
\text { faste og ad hoc opgaver er optegnet, } \\
\text { så alle kan se, hvad der skal laves af } \\
\text { kontoropgaver og praktiske opgaver i } \\
\text { dagens løb. Der er en medarbejder, } \\
\text { fire medlemmer og antropologen til } \\
\text { stede. Frans spørger David (M), som } \\
\text { sidder og kigger ned i gulvet, om han } \\
\text { kan støvsuge. David svarer } \\
\text { bekræftende. Frans vil vise David, }\end{array}$ & $\begin{array}{l}\rightarrow \text { Der er morgen-enhedsmøde i } \\
\text { Kontoret. Fem medlemmer og en } \\
\text { medarbejder drøfter weekendens } \\
\text { oplevelser, mens antropologen lytter } \\
\text { med. Men så siger Knud (MA): "Nå, } \\
\text { Hr. Ordstyrer!". Jes (M), som skal } \\
\text { afholde dagens møde går hen til } \\
\text { tavlen og læser formiddagens opgaver } \\
\text { højt. Nogle af opgaverne fordeles. } \\
\text { Undervejs gennemgår de } \\
\text { medlemsfremmødet i fællesskab. De } \\
\text { stopper op og snakker om, hvem der } \\
\text { tager 'Dagens Avis' } 27 \text {, for nogle er kørt }\end{array}$ \\
\hline
\end{tabular}

${ }^{27}$ Dagens Avis produceres den forudgående dag af Kontorenheden (FH $\AA$ ). Det er en 'flyer' opstillet på alle borde i Kantinen, så alle kan se, hvad der sker i dagens løb, møder, aftaler, fødselsdage, hvad der er på menuen til frokost, dagens vejr, hvad der er sket på datoen ude i 
hvor støvsugeren er efter mødet, siger han. Resten af formiddagens opgaver fordeles mellem de tilstedeværende, som selv byder ind eller opfordres af medarbejderne med et "Var det noget for dig?". Men der er stadig muligheder for at bidrage tilbage: Frans spørger David, om han kan noget med at lave labels på computeren. David: "Nej, jeg ved ikke, hvordan man gør". Frans spørger, om han har lyst til at vide det, for det er nemlig noget Bjørn (M) kan. David svarer "Nej tak". Frans og Bjørn udveksler et blik. Så er mødet slut. "Nu skal jeg lige vise dig støvsugeren", siger Frans. David støvsuger hele Kontorområdet med stor grundighed $\leftarrow$ (Feltsekvens Kontoret FH K mandag den 12.april 2010) lidt træt i opgaven. Gertrud (M) siger, at "Så må vi skiftes mere om opgaven". Knud: "Det er måske godt nok at holde det ved lige". Gunna (M): "Er vi gået $i$ stå Jes?". Så kommer der gang i opgavefordelingen igen. Gunna: "Vi skal være opmærksomme på, at jeg gerne vil lare noget mere i de perioder, jeg kan". Knud: "Ja, det skal vi. Lad os lige tage den bagefter". Gunna byder ind på en opgave med det samme. Knud: "Gunna, er det nok med den opgave, eller vil du mere i dag?". Gunna: "Ja, ellers tager jeg en gang rengøring. Måske er det heller ikke så aktuelt lige $i$ dag, for jeg tager også lige en time og slapper af oven $p a ̊ \prime<$ (Feltsekvens Kontoret FH fredag den 12. marts 2010)

Der er generelt en veloplagt indstilling til både at byde ind og sige ja til beskrevne/kendte opgaver og nye udfordringer. Det kan både være medarbejderens støtte til arbejdsmotivation som i feltsekvens A, hvor medarbejderen har blik for, at medlemmet får mulighed for at bruge den arbejdsevne han har. I tillæg søges et andet medlems udvidede arbejdsevne også sat i spil (via varetagelse af sidemandsoplæring). Det kan også være medlemmet, der selv er hoveddrivkraft til udvirkning af arbejdsmotivationen som i feltsekvens B. Her gør medlemmet selv opmærksom på sine ressourcer til at bidrage mere for at få hjælp til at sætte det i værk. Medarbejderen griber forespørgslen og vil følge op.

\section{At være klar til FH}

Understregninger om vigtigheden af 'at være klar til Fontæne Klubhusene' ser ud til at rumme viden om, hvad medlemskab indebærer for medlemmerne i Klubhusene. At være klar er nemlig medlemmernes kategori forstået på den måde, at det først var medlemmer, der gentagne gange gjorde mig opmærksom på, nærmest som en selvfølgelighed, at "Man skal jo være klar til FH".

verden, et citat i form af nogle ord til eftertanke eller en vittighed. Dagens Avis læses højt til det fælles morgenmad-mødet i Kantinen kl. 8.45-9.15. 
Dermed tolker jeg, at der er noget, som kan siges at samle dem der udlever klubhusmedlemskab, forskelligt fra 'de andre' der ikke er klar. Men analysen viser, at det at være klar er ikke er en tilstand, som medlemmerne er eller ikke er i - Det vil sige noget, der stabilt er og med det, at det er, er der adgang til medlemskab. Det er nærmere en måde hele tiden at udleve sit medlemskab.

På vej hjemad i bussen forklarer Gunner (medlem FH K), at den slags præcis er en proces med flere 'faser', som man er $i$ i sit medlemskab: "Sådan er det meget $i$ starten, at så sidder man der og er med på den måde, at man kan sidde med noget eller gøre noget, uden at der kræves en hel masse mere af en, indtil man kan klare mere eller har lyst til mere. Det tog mig da sådan to år at nå dertil". Brian (medlem FH K) fortæller om sin oplevelse med Fountain House: "Her kan man gå og komme lige så stille i gang". Adgang til medlemskab er en løbende proces, om at udvirke medlemskab på en 'være-klar-måde'.

\section{At være klar er at vise og udleve sin arbejdsmotivation}

Det at være klar til FH kan overordnet siges at betyde, at det individuelle medlem i ord og handling siger/viser ja til, at han/hun er motiveret til at deltage i Klubhusets daglige drift.

Det er indirekte et ja til 'hele modellen' som strukturerende organisator af fællesskabet, og dermed af omgangsformerne i enhedsarbejde og social træning, som tegner Dagprogrammet i Klubhusene helt overordnet. 'Ja til modellen' er dermed at indgå i vekselvirkningen mellem enhedsarbejdet (møder, fordeling, arbejde, samarbejde etc.) og det sociale liv i pauserne.

Men forskellige medlemmer kan, inden for det enkelte Klubhus praksis, indgå på forskellige måder. I Fontæne Huset i Århus holder alle for eksempel pauser sammen. Folmer (medlem FH Å) forklarer: "Det kan godt ske, der sidder en henne i hjørnet for sig selv; men det er kun noget folk gør en gang imellem - det er jo ikke hver dag. Eller det er fordi, de bare vil sidde $i$ skyggen"(G 4.6.2010). Nogle sidder og snakker i pauserne (smalltalk om 'vejr og vind', Klubhuset, rejser, tvprogrammer, blondinevittigheder etc.), nogen er 'med på en lytter', man kan også læse avis eller tage sig af salg af kaffe. Men oplevelsen er alligevel at være sammen med alle dem, der er i huset den pågældende dag.

I Fountain House København behøver medlemmerne ikke at spise frokost eller drikke kaffe sammen med alle de andre, eftersom den måde pauserne afvikles på er 'frivillig'. Det kan være et tilbud: "Vil du med op og drikke en kop kaffe David, for det er pause nu, eller vil du hellere sidde her lige så stille?" (Ester, medarbejder FH K), det kan være for meget og dermed føre til individuel tilvirkning: "Uh, nej pause, det kan jeg slet ikke finde ud af. Jeg bliver her, og jeg er også i gang med mapperne" (Oda, medlem FH K), eller det kan bruges til at bryde arbejdsomheden, som er villet men hård, lidt op: "Den her opgave, den kræver en 
kop kaffe" (Filippa, medlem FH K). Det kan være man går op i Cafeen, og så er det alligevel for overvældende at finde en plads blandt 'mylderet' deroppe, eller det kan være man lige møder nogen man kender, som man slår en sludder af med.

I selve arbejdet i Enhederne ser det også ud til, at der er plads til individuelle måder at indgå i Dagsprogrammet. "For nogle er deres bidrag, at de kan komme herhen og møde til tiden - og det er fint" (Fie, medarbejder FH Å); men der kan også spores stærkere krav om at være i en proces med at deltage og bidrage på en mere stringent klubhusmåde: "Han kom og læste avisen og gik hjem igen, og det er jo ikke meningen med det" (Knud, medarbejder FH Å).

Den motivation medlemmet kommer med, kan have mange udtryk og den kan være forskellig fra dag til dag. Men analysen viser, som jeg kommer tilbage til, at stabilitet er et grundlag for mulighed for udtryksmangfoldighed i måder at udleve arbejdsmotiverethed på for det enkelte medlem. Som Andreas (medlem FH Å) udtrykker det, "Ja, der er selvfolgelig en eller anden forventning om, at vi møder til tiden, og der er også en slags forventning om, at man så også deltager $i$ arbejdsopgaverne, at man byder ind med noget, man gerne vil arbejde med. Men alligevel står der jo $i$ standarderne, at man har ret til at sige fra, og der er et frivillighedsprincip $i$ det, så man kan sådan set komme og skrælle den her berømte kartoffel og så sidde og ryge cigaretter. Det skulle sådan set være i orden"(G 4.6.2010).

Der opleves altså en frihed til at komme og yde netop sit bidrag som lige såvel som at 'skrælle den berømte kartoffel' på en dårlig dag, i en god periode kan være med sidemandsoplæring af et par andre interesserede medlemmer at stå for hele den murefaglige arbejdsproces i en delopgave af den store ombygning af cafeområdet, det kan være at stå for det store Landsmødeprogram, eller passe receptionen med omstilling, regnskab og 'det hele'. Det kan være at indgå sammen med seks andre i en stor opgave med samarbejde om koordinering af alle de arbejdsprocesser, der indgår i pakning, frankering, adressering og forsendelse af medlemsbladet, eller at udarbejde et regneark helt fra grunden med lidt hjælp fra en medarbejder, eller at lave kødsovs sammen med en medarbejder. De finder sammen ud af, hvordan medlemmet kan komme til at udleve sin arbejdsmotivation indenfor Klubhuset muligheder herfor:

$\rightarrow$ Ivar (M) og Fie (MA) sidder og snakker efter enhedsmødet. Ivar vil godt hjem igen, for han har det ikke godt. Fie spørger, om han ikke lige vil være med i køkkenet lidt. De skal lave kødsovs. Men det er han ikke rigtig stemt for.

Fie: "Måske lige en halv time?"

Ivar: "Nej, jeg vil ikke blive". Men han bliver alligevel siddende og lytter med, da Andreas (M) spørger om forskelligt vedrørende den tomatsovs, 
han skal til at lave til vegetarerne. Da Fie og Andreas har aftalt hvordan og hvorledes med tomatsovsen, kigger Fie på Ivar og tager tråden op:

Fie: "Ivar, det er jo ikke, fordi du skal være her hele dagen, men nu er du kommet herind, og så skulle du da næsten lige lave noget også?"

Ivar: "Godt nok så"

Fie: "Godt. Så laver vi noget arbejde, og så tager du hjem, hvis du er mest til det" Ivar: "Så laver vi kødsovs"

Fie: "Godt du er her"

De snakker 'kokkesnak' om forskellige råvarer.

Fie: "Du skal jo også lige i gang igen. Lad os få skjorter på, og så komme af sted over og finde log frem og sådan"

I løbet af formiddagen arbejder Fie og Ivar sammen om kødsovsen, og Ivar smager til sammen med Andreas og finder ud af, at han også vil lave den derhjemme til weekenden, for den er god i flere dage $\leftarrow$ (Feltsekvens FH Å fredag den 19.marts 2010)

\section{At være klar er at gøre stabilitet}

Det er fælles for de Klubhuse, jeg har besøgt og bedrevet mine feltstudier i, at medlemmerne som udgangspunkt forventes at møde op og deltage i enhedsmødet, hvor fremmøde skemaer føres, overblik over dagens opgaver skabes, opgaverne fordeles og samarbejdsrelationer aftales. Enhedsmødet er en væsentlig del af Dagsprogrammet ${ }^{28}$.

Som Andreas (medlem FH $\AA$ ) sagde, oplever han "en eller anden forventning om, at vi møder til tiden, og der er også en slags forventning om, at man så også deltager $i$ arbejdsopgaverne, at man byder ind med noget, man gerne vil arbejde med" (G 4.6.2010). Senere i samtalen uddyber han: "Vi har jo vores morgenmøder, hvor vi planlægger dagens arbejde, og det er selvfølgelig nødvendigt, for at det overhovedet kan løbe af stablen det hele"(G 4.6.2010). Nogle sidder med rundt om bordet, andre holder sig lidt mere på afstand. Nogle melder hurtigt ind på foretrukne opgaver, andre kommer med sådan som Ivar ovenfor via medarbejderens lydhørhed for hans arbejdsmotivation. Som August (medlem FH Å) udtrykker det: "Man behøver ikke sætte sig lige i midten af cirklen hver dag vel. Der er plads til, at man kan sidde for sig selv, altså trække sig lidt tilbage hvis man ikke lige synes, man er $i$ hopla den dag. Jeg har også dage, hvor jeg er mere stille end andre dage"(G1.6.2010).

Det er interessant i denne sammenhæng, at der kan siges at være en udtalt bevidsthed hos medlemmerne om, at det er vigtigt at vise og arbejde med sit tilhørsforhold til Klubhuset ved at indgå i Dagsprogrammets organisering af

28 "... Der afholdes enhedsmøder med henblik på at udvikle såvel frllesskabsfølelse som at organisere og planlægge dagens arbejde" Uddrag af Standard nr. 18 (I: Retningslinjer for klubhuse) 
aktiviteter. Det vil for eksempel sige at møde til tiden og deltage i fordelingen af opgaver.

"Jeg svarer ikke godmorgen, hvis jeg kommer for sent, for så har jeg dårlig samvittighed" (Harald, medlem FH K). "Jeg tog en taxa de halvanden kilometer, for ikke at komme for sent" siger Filippa (medlem FH K), som har været ustabil et stykke tid. Hun arbejder ihærdigt med at blive et stabilt medlem med tilhør ved at stille spørgsmål, der viser lyst og arbejdsevne til at gennemføre og have overblik over arbejdsprocessen, der hører til den opgave, hun arbejder med, spørge efter nye arbejdsopgaver hun kan engagere sig i at lære, og stråle i ansigtet når medarbejderen siger, at der er en arbejdsopgave til hende. Det er tydeligt, at det bliver der, efterhånden som hun har haft flere dage med stabilt fremmøde.

Ved at være stabil kommer medlemmet 'ind i sagerne' (igen måske), og han/hun opfattes af andre ved sin arbejdsmotivation frem for ved sin ustabilitet. Arbejdsmotivation kan imødekommes i en Klubhusorganisering af samvær. Ustabilitet kalder på opfordring til forandring til stabilitet.

"Jeg sov over mig, det er jeg ked af", siger ellers stabile Gertrud (medlem FH $\AA$ A) gentagne gange en dag, hun først når frem lidt efter enhedsmødet. "Jeg troede det var søndag, da jeg vågnede, det er derfor, jeg kom for sent til mødet", forklarer Marianne (medlem FH K). Andreas fortæller, at han underretter Klubhuset, hvis han bliver forsinket og understreger, at det er et halvt år siden, han var ustabil i sin fremmødeaftale: "Men så ringer man jo bare herned og siger 'Jeg kommer lidt senere $i$ dag', og så er det også altid $i$ orden. Så kan det være, de sætter en parentes om en arbejdsopgave til mig ... men det er også over et halvt år siden, jeg ikke er mødt op" (G 4.6.2010).

Når analysen vedrører medlemmernes udlevelse af stabilitet, har forpligtetheden udtryk af positive personlige konsekvenser. Bjarne siger, at "Jeg synes, det er simpelthen overlevelse at komme her. Jeg ville sumpe, hvis jeg ikke kom her. Der er jo også dage, hvor jeg ikke synes, det er sjovt; men så tager jeg det ligesom et arbejde: Der skal man komme jo"(G 1.6.2010).

Alternativet til stabilitet er 'at sumpe', og stabiliteten giver anledning til, at medlemmet mærker, at han/hun er med til at få 'det hele til at løbe af stablen'. Det er altså ud til, at medlemmerne prioriterer at arbejde med stabilitet i deres måde at bruge huset med de positive personlige konsekvenser det har. "Med Fountain House, ja, her far jeg noget struktur og dagen organiseret", forklarer Bjørn (medlem FH K).

I hverdagslivet i Enhederne kommer medlemmernes måde at udleve stabilitet for eksempel til konkret udtryk ved, at de selv tager en udfordring. Som Gunna og Filippa i feltsekvenserne ovenfor, der begge giver udtryk for at de gerne vil lære noget mere. Når de kan flere af Enhedens opgaver, kan de i højere grad indgå i det daglige arbejde og samarbejde. Dagen bliver nemmere 
at 'forudsige' og tilhørsoplevelsen bliver større. Eller det kan være ved at tage imod 'et prik' om noget, der kunne vise sig at være en god udfordring. Som David og Ivar ovenfor der på deres måder (på trods af at de har det skidt), med deres arbejdsindsats og støtte fra medarbejderne kan opleve, at de kan bidrage til at løse arbejdsopgaverne støvsugning og kødsovs, der gør fællesskabet godt. Der er perspektiver for mere i alle typer bidrag.

Medlemmernes stabilitet er en proces, de arbejder med ved at komme og sige ja til og gøre det, de kan den pågældende dag, sådan som de har det fortiden, eller der hvor de er i deres rehabilitering. De understøttes af udtalelser så som "Godt du kom" og "Hellere at du er kommet, end at du lå derhjemme" fra medarbejderne, hvis den psykiske dagsform ikke er helt i top.

\section{Medarbejderne vedrørende medlems-klar-hed}

På et førstegangsbesøg, jeg fulgte i Fontæne Huset i Århus stoppede medarbejderen det kommende medlem i tale om diagnose og psykiatrisk behandlingsplan. Efter kort tids samtale undervejs i rundvisningen, bemærkede jeg, at det kommende medlem begyndte at bruge udtryk som "Det er godt at blive udfordret" og talte om "ressourcer og muligheder". Medarbejderen bemærkede vist også forandringen i ordvalg, for han sagde, at "Man må selvfølgelig godt snakke om det, hvis man har lyst. Vi gør det bare ikke ret meget ... Det er vi egentligt ligeglade med her. Vi snakker mere om arbejdet, og hoad vi skal $i$ weekenden og sådan" (Knud, medarbejder FH $\AA)^{29}$.

Det er altså arbejdet, fremmødet og 'det man skal i weekenden', der er vigtigt, det vil sige almindelige arbejdspladsemner ikke sygdom og besværligheder af mere privat karakter. Man kan også sige, at det er medlemmet ved hans/hendes ressourcer eller hans/hendes arbejdsmotivation, der er interessant i Klubhussammenhængen.

Dermed kan man sige, at medlemmerne skal være klar til at skelne mellem, hvad der hører til i Klubhusfællesskabet, og hvad der hører til andre steder: "Dem, der bliver her, det er vel dem, udfordringer passer til" siger Betty (medarbejder FH Å), ligesom det understreges at "De fleste har jo også en tilknytning til lokalpsykiatrien. Bostøtter og sådan. Så det er mest, hvordan medlemmet har det her i Fontæne Huset, vi går ind i" (Betty, medarbejder FH Å) ${ }^{30}$.

\footnotetext{
${ }^{29}$ Bjarne (medlem FH Å) fortæller, at "Så vidt jeg har kunnet se, så har medarbejderne en politik om, at man ikke snakker sygdom. Og det synes jeg egentligt et eller andet sted er dejligt" (G 1.6.2010). Således understøtter medarbejdernes klubhustilgang om fællesskab om driften i arbejde og socialt liv også medlemmernes behov for et sted, hvor fokus er anderledes end i psykiatrien.

${ }^{30}$ Her skal det nævnes, at der kan spores en forskel mellem FH Å hvor holdningen er, at man fortrinsvis beskæftiger sig med det, der vedrører medlemmets gang i Klubhuset, og så Kildehuset i Nørresundby. Der er holdningen, at der er meget vide rammer for, hvordan der ydes støtte til det enkelte medlem: "Det er helhedssynet på medlemmet, der er i fokus. Derfor er der
} 
Frans (medarbejder FH K) overvejelse, på baggrund af hans erfaring med opstartsprocesser med nye medlemmer handler om, at "Hvis de ikke kan klare de ti timers introduktion $i$ alt, der ligger fordelt hver anden dag de første to uger, så er de måske heller ikke klar". Understregningen af at Klubhusene ikke er væresteder er tydelig.

Med blik på medarbejdernes tilgang under en vinkel om klar-hed, skal der også være en udlevelse af vi-følelse knyttet til den stabilitet det indebærer at indgå i et arbejdsorganiseret fællesskab, hvor hvert enkelt medlem udfylder en nyttig plads i driften af huset. Det at være ustabil og sige " $I$ " falder helt udenfor og udtrykker absolut ingen klar-hed: "Han kommer næsten aldrig, og når han kommer, siger han 'Skal I ikke ...' og så var jeg nød til at tage en snak med ham om det, og om at blive mere stabil igen" (Knud, medarbejder FH $\AA$ ).

Klarheden vedrører her en ansvarsforpligtelsesfølelse af at være del af et vi, som får huset til at 'køre på skinner' netop ved fælles hjælp. "Vi skal overveje, om det hun vil have os til at være i sit liv, er noget vi som Klubhus overhovedet vil og kan være - Måske har hun ikke arbejdsmotivationen mere, og så er det ikke det rigtige sted længere", siger Betty (medarbejder FH Å) ved en henvendelse fra et tidligere medlem.

Det er også tydeligt, med blik på medarbejdernes tilgang, at Klubhusene heller ikke er behandlingssteder ${ }^{31}$. "At være klar, det er ikke det, at være klar til behandling eller sådan noget; men det er, at være klar til det der kommer $i$ spil, når man er $i$ det her fxllesskab", forklarer Betty (medarbejder FH Å) mig, da jeg spørger, hvad hun mener, der ligger i udtalelser som, "Man når jo først Fontæne Huset, når man er klar til det. Der er jo først nogle andre processer, man skal igennem, som gør, at man så vælger Fontæne Huset"(August, medlem FH Å). Fritze (medarbejder FH K) gør følgende status, efter vi har snakket om medarbejdernes opgave: "Vi laver ikke behandling, sådan et sted er det her ikke; men vi kan ikke udelukke at det der foregår, kan have terapeutisk effekt for medlemmerne - de komme jo videre, de kan studere igen og så rykker de sig $i$ det hele taget".

Som tidligere nævnt fastholder Klubhusene arbejdsorganiseringen. Og i denne optik medvirker det til, at Klubhusene bliver noget for nogen. Som Minna (medarbejder FH Å) sagde, fastholder de det bevidst på trods af at det nok

flydende grænser for vores omsorg. Vi er faktisk til rådighed 24 timer i døgnet, hvis der er behov for det" (medarbejder FH N). I Fountain House København mødte jeg følgende holdning fra medlemmerne: "Jeg er overbevist om, at medlemmerne ikke går til medarbejderne med 'hvad som helst', for vi kan jo sagtens se, at de er stressede og har meget om ørerne" (Lisbeth, medlem FH K); men det understreges også i FH K, at ressourcerne til et bredt medlemstilbud om støtte 'ud af huset', er til stede qua den fagligt blandede medarbejdergruppe: "Vi har jo netop socialrådgiverne $i$ huset, som vi kan bruge til kontakt med kommunen og sådan" (Marianne, medlem FH K).

31 "Klubhuset har egne lokaler. Lokalerne er adskilt fra distriktspsykiatriske centre og institutioner i det hele taget og kan kun benyttes af klubhuset ..." Uddrag af Standard nr.13 (I: Retningslinjer for klubhuse). 
skræmmer nogen væk. Som August (medlem FH Å) siger herunder, så er Fontæne Huset godt, hvis man gerne vil optræne sin arbejdsevne mens det ikke er godt, hvis man har sig selv på programmet ifølge Asta (medlem $\mathrm{FH} \AA$ ).

$\rightarrow$ Fontæne Huset i Århus har møde med besøgende fra Klubhuset i Jelling om, hvordan klubhusmodellen står i forhold til Århus Kommunes recoverytilgang inden for psykiatrien. I drøftelsen finde følgende ordveksling sted mellem nogle af de deltagende medarbejdere og medlemmer:

Betty (MA): "Hvad nu, hvis man kommer her og har en drøm om at være udøvende kunstner, det er vel lidt sværere?"

Knud (MA): "Det kan være, man kan lave det $i$ det sociale program ${ }^{32 "}$

Minna (MA): "Skal man yde for man kan nyde her?"

Fie(MA): "Nej, man kan være med til at præge det ekstra et Klubhus kan, hvis man er med $i$ det arbejdsorganiserede"

August (M): "Det kommer an på, hoad ens mål er. Hvis man er rettet mod at optræne sin arbejdsevne, så er Fontæne Huset jo godt"

Asta (M): "Musik, ja altså kunst, jeg synes, det er mere rettet mod en selv; arbejde er noget man laver sammen"

Knud: "Ja, det er lige netop kernen i Klubhusene, det I der siger. Den, der takker dig, er den lige ved siden af dig" $\leftarrow$ (Feltsekvens FH Å onsdag den 10.marts 2010)

Fra medarbejdernes side lægges der vægt på, at det at være klar er at indgå med det, det kræver for at være del af fællesskabet. Altså først og fremmest at yde sin arbejdsindsats i det arbejdsorganiserede Dagsprogram med de udfordringer det giver anledning til. Som Betty (medarbejder FH Å) udtrykte ovenfor, er det at være klar at kunne være i det der kommer i spil, når man er i sådan et hus, hvor der er arbejde og fællesskab. Det er ikke at bruge huset som værested og det er ikke at forvente behandlingsindsatser. Det kræver derimod den enkeltes udvirkning af sin arbejdsmotivation med hensyntagen til fællesskabet.

Hvis man er med i det arbejdsorganiserede giver det adgang til de muligheder som medlemmerne kan bidrage til at lægge i det sociale program via aktiviteter, der er anderledes end enhedsarbejdet, som Fie (medarbejder FH

\footnotetext{
32 Ud over enhedsarbejde og pauser indebærer Dagprogrammet også mulighed for deltagelse i Klubhusenes sociale program, som består i aktiviteter, der ligger ud over enhedsarbejdet. Det kan være i arbejdstiden i form af deltagelse i for eksempel foredrag, gæstebesøg og pausegymnastik, eller ture om eftermiddagen på museum, ugentlig fitness, fejring af fødselsdag, håndarbejdsgruppe, klubaftner mv. Initiativet hertil kan være medlemmernes såvel som medarbejdernes. Det pointeres altid, at deltagelse er frivillig.
} 
Å) gør opmærksom på i feltsekvensen. I Fountain House København har nogle medlemmer startet en gruppe der laver håndarbejde om onsdagen, og tidligere har der været en musikergruppe, der har øvet i kælderlokalerne, fortæller Gunner (medlem $\mathrm{FH} \mathrm{K}$ ) på rundvisningen.

Knud (medarbejder FH $\AA$ ) roser de to medlemmer August og Asta for at understrege det særlige ved Klubhusene: Med August at Klubhusene er for nogen der vil gøre noget ved deres arbejdsevne (her kan man sige, at det kan være fremmende for blikket på medlemmet som medlem med klubhustilhør, at han/hun bruger ord, som udtrykker en oplevelse og brug af Klubhuset som noget, der befordrer det, der omhandler det Klubhusorganiseringen (i arbejde og pauser) kan give medlemmerne). At gøre det, er en måde at vise klar-hed på i samspillet med medarbejderne.

\section{Del 2. At gøre medlemskab og medarbejderprofessionalisme}

Det fremgår nu, at det at være et forpligtet medlem ikke er en tilstand, det enkelte medlem er i, altså noget færdigt medlemmerne kommer ind i huset med. Det er nærmere en proces ved det at vælge at komme og være medlem i Klubhusene i kortere eller længere tid med det det kræver om deltagelse i det arbejdsomme og sociale fællesskab hver eneste dag. Via det forpligtede medlemskab bruger medlemmet sine muligheder for at udleve sin arbejdsmotivation inde i samspillet i Klubhuset, med modellen som levet idebaggrund for rehabilitering.

Her i del 2 ser jeg på betydningen af kontinuitet (uddyber stabilitetsaspektet ovenfor) og medarbejdernes professionelle træden i karakter (analyse af medarbejdernes side af samspillet). For det har at gøre med, hvordan medlemskab gøres og hvad der ligger i medarbejderprofessionalisme i Klubhusregi.

\section{Kontinuitet har betydning}

I Fontæne Huset i Århus, som var det første Klubhus jeg gjorde bekendtskab med, blev jeg præsenteret for den arbejdsstrukturerede dag i praksis. Den foregår i form af et forud tilrettelagt program for møder, arbejde og pauser i en konstant vekselvirkning.

I de Klubhuse jeg har været på feltstudier, er det forskelligt, hvor stramt strukturen 'overholdes' i det levede liv i Klubhuset. Men på trods af lokale fortolkninger, er Dagsprogrammet som en levet struktur under alle omstændigheder særdeles genkendelig i samspillet mellem medarbejdere og medlemmer. 
Det, uanset om den er der som 'mulighed' som i Fountain House København med møder for dem, der vælger at deltage, mundtlige påmindelser om 'nu har vi faktisk enhedsmøde' et par minutter over 10, 'nu er det pause, hvis nogen skal nå at købe kaffe inden Cafeen lukker' eller 'hov, det er faktisk ved at være frokosttid' og opslag på væggen om i hvilket tidsrum, Cafeen har åben eller pludselig har selvbetjening i åbningstiden, fordi Fontanas medlemmer nyder forårssolen; eller om programmet følges til 'punkt og prikke', præcist som det er beskrevet på klokkeslæt. "Skal jeg komme med noget opløsningsmiddel, jeg synes I klæber til stolene" (Barbro, medarbejder FH Å), og med klare forventninger om at alle deltager i pauserne som holdes i Kantinen (også når der ingen medlemmer er til stede i huset), at man skiftes til at være den der styrer enhedsmødet, tage referentrollen på Husmødet, som det ses i Fontæne Huset i Århus.

Ifølge medarbejderne i Fontæne Huset i Århus er det, der sker i hverdagen, når medlemmer og medarbejdere fungerer sammen inden for modellens arbejdsstrukturerede dag, at de er kulturbærere: "Vi er jo hver især kulturbærere, når vi arbejder her sammen" (Knud, medarbejder FH Å). "Vi er sammen om at opretholde kulturen, fordi alle er bevidste om den", uddybes det.

De gentager og gentager og gentager Dagsprogrammet og de organiseringer og samværsformer det indebærer. Det bidrager medarbejderne i høj grad til. For eksempel ved henvisninger til Dagsprogrammet: "Hmm hmm "siger Knud (medarbejder FH Å) og stiller sig for enden af et bord i Kantinen, hvor ingen har gjort ansatser til at rejse sig selv om klokken er 11.00. Da der skal være temadag i huset styret af en konsulent fra kommunen, understreger en medarbejder over for medlemmerne og medarbejderne dagen før: "Men det er alligevel som det plejer, for det med pausetider og sådan, det laver vi ikke om pä" (Minna, medarbejder FH $\AA$ ). Og de deler opgaverne i Enhederne med medlemmerne: "Jeg kan tage toiletterne i dag" (Fie, medarbejder FH Å). Der er masser af henvisninger $i$ hverdagen til organiseringen $i$ vekselvirkningen mellem enhedsarbejde og pauser.

Ud over medarbejderhenvisninger så som Knud og Barbro ovenfor der, med et 'hhm' og en sjov 'pedelfaglig' bemærkning om at hente opløsningsmiddel, henstiller til at der ikke holdes pause længere end til kl.11.00, eller direkte henvisninger til arbejdsorganiseringen med streg under at det netop er et arbejdsfælleskab: "Så, vi må videre [afbryde mødet $\mathrm{AH}$ ], vi har også produktionen at tage hensyn til" (Frans (medarbejder FH K), ses også henvisninger fra medlemmerne så som: "Skal jeg lige hente kalenderen" (Gunhild, medlem FH $\AA)^{33}$. Medlemshenvisninger af den karakter støttes af

${ }_{33}$ Under feltarbejdet undrede det mig mange gange, at medarbejderne som ofte sad med kalenderen (ovre i Enheden) ikke tog den med over i Kantinen, hvor den bruges på et fast tidspunkt, umiddelbart derefter, hver dag. Først under analysearbejdet blev det tydeligt for 
medarbejderne: "Har vi ikke frokost nu?" (Lotte, medlem FH K); "Jo uhh, det må vi ikke glemme" (Frans, medarbejder FH K), og "Vi skal have møde, hører I efter eller hvad?" (Kurt, medlem FH Å); "Det er godt, du kan skære igennem" (Knud, medarbejder FH Å). Henvisningerne medvirker til at forme den sociale ramme de er i sammen, så den kommer til at udtrykke forudsigelighed og kontinuitet for sine mennesker.

I feltsekvensen herunder påtager medlemmerne sig selv at vedligeholde kontinuiteten gennem henvisning til gentagelse af, hvordan de plejer at arbejde (sammen) og følge organiseringen (om at al information kommer ud til alle interesserede).

Medlemmernes gentagelse af strukturerne kommer dermed til at forme deres samspil med hinanden og med den eksterne rygestopkonsulent. Retningslinjerne leves så at sige via medlemmernes fælles levendegørelse af 'formalia' (retningslinjerne) via deres samspil.

$\rightarrow$ Det er sidste møde i rygestopgruppen, som i dag består af fem medlemmer, en sosu-praktikant og antropologen. Efter en runde om hvordan det går for hver enkelt, siger den udefrakommende rygestopkonsulent, at hun gerne vil komme forbi til en opfølgningsdag om nogle uger. Det vil deltagerne gerne have. Men så er der et medlem, der foreslår, at de jo også selv kan fortsætte de ugentlige møder og bakke hinanden op i deres rygestop. Alle synes, det er en god ide. Konsulenten foreslår, at de vælger en tovholder til at stå for det, for "Så er der større sandsynlighed for at lykkes med sådan en ide", siger hun. Med det samme korrigerer August (M): "To personer - for her på stedet har vi det med at samarbejde to og to om tingene". De holder en pause, og efterfølgende gør medlemmerne status over deres travlhed/andre opgaver. Augusts forslag er åbenbart vedtaget: To af medlemmerne påtager sig at være tovholdere. Den ene tager initiativ til at hente husets fælles-kalender, for "Så går det rigtigt for sig og kommer med $i$ Dagens Avis, når vi har møde" siger Gertrud $(\mathrm{M}) \leftarrow$ (Feltsekvens FH $\AA$ tirsdag den 23.marts 2010)

Italesættelser af praksis og opgangsformer reproducerer praksis og omgangsformer. "I smiler altid så venligt"/ "I siger altid så pænt godmorgen", kommenteres det til receptionisterne i FH K - og så fortsætter det og kommenteres igen ...

Til daglig demonstrerer medarbejderne og medlemmerne i Klubhusene altså Dagsprogrammet og de procedurer og omgangsformer, der hører med

mig, hvor stor en reproduktionskraft af Dagsprogrammet (helt ned i mindste detalje) der ligger $i$ at lade det være et fælles ansvar - og dermed i høj grad et medlemsansvar at procedurerne gentages. 
over for hinanden, i den detaljeringsgrad der præger det enkelte Klubhus. Herved fremstår strukturerne som noget helt selvfølgeligt. Strukturen får en levende kontinuitetskarakter. Fie (medarbejder FH A) forklarer mig på min rundvisning den første dag, at "Der er ingen overraskelser her. Man kommer her som medlem, og så ved man med sikkerhed, hvad der sker". Folmer (medlem FH Å) oplever, at strukturen via Dagsprogrammet hjælper ham så han får stabilitet $\mathrm{i}$ sin hverdag: "De forsøger at hjælpe en med at bygge en ordentlig hverdag op, så man får en stabil uge" (G 4.6.2010).

Således har den måde, man er sammen på i Klubhuset, som fastholdes ved, at alle medvirker og forventes at medvirke til fastholdelsen personlige konsekvenser for medlemmernes rehabiliteringsmuligheder.

Alexander (medlem på besøg fra Klubhuset i Jelling) siger, at hans oplevelse de seneste dage er, at "I Fontæne Huset er det jo næsten til at tage og fole på strukturen, selv om struktur jo i virkeligheden slet ikke er en håndgribelig størrelse".

Harald (medlem FH K) understreger vigtigheden af kontinuitet i form af kendte strukturer for arbejde og socialt liv, for han siger, "Det er ikke så godt at komme et sted og opleve en grad af kaos i stedet for en grad af struktur, når man har det sådan lidt dårligt - Eller hvis det er nemt at finde ud af, hoad det er for nogle opgaver, man skal lave, så er det også godt".

Det giver anledning til bekymring, hvis strukturen i Dagsprogrammet ikke er 'stærk nok', det vil sige, hvis den ikke varetages af både medlemmer og medarbejdere i et kontinuerligt samspil.

Det er problematisk, hvis der ikke er nok kontinuitetsbærere blandt medlemmerne (det langsomme vand i bækken, som de kaldte det i Århus), fordi "Når der ikke er nok af de gamle, kommer rigtig mange opgaver til at hænge på medarbejderne, som ellers skulle varetages både af medlemmer og medarbejdere" (Frans, medarbejder FH K). "Der er ikke nogen, der ofrer sig og kommer og tager det ansvar" siger han, så kontinuitet kan blive etableret via det, at mere erfarne medlemmer kan tage nye 'under vingerne' og dermed medvirke til, at nye får en god start og bliver del af 'det hele', herunder også at den ligeværdige omgangsform mellem medarbejdere og medlemmer bevares. Lotte (medlem FH K) oplever, at "Der er ikke så mange af de gamle, altså nogen som kan det. De kommer enten sjaldent, eller de er der ikke den dag, man havde koblet sig på dem".

Der er dog ansatser til at tage sådan et ansvar blandt de mest stabile: Lotte (medlem FH K) kommer selv en eftermiddag 'bare' for at lære Frode (medlem FH K) op i et pc-program, hun ikke engang selv føler sig helt sikker på, og Frans (medarbejder FH K) prøver sammen med Bjørn (medlem FH K), som tydeligvis er med på ideen, at få sidemandsoplæring i gang med David (medlem FH K), som godt nok afslår - De kigger indforstået på hinanden, da Frans foreslår det, og med ærgrelse da David takker nej. Mads (medarbejder FH 
K) fortæller om 'sin' Enhed: "Vi har nogle få stabile kræfter i nogle medlemmer, som de dage de ikke er ude i arbejde kommer her og faktisk driver den Enhed".

Nye medlemmer tilskyndes til at overholde mødetidspunktet: "Jeg må opfordre jer til at komme til enhedsmødet" / "Det ville være rigtig godt, hvis du kunne øve dig på at komme til kl. 10" siger Frans (medarbejder FH K) gentagne gange til flere af de nye medlemmer i introforløbene. På trods af at opfordringen er tydelig for alle, møder de øvrige medlemmer heller ikke altid 'til tiden'.

Frustration vedrører, at der netop går 'kludder' i organiseringen. For i stedet for at arbejdsopgaverne er klare og tydelige for alle og fordeles lige mellem alle via tavlegennemgang på enhedsmødet, må opgaverne fordeles af medarbejderne, efterhånden som medlemmerne kommer 'dryssende'.

Det har konsekvenser for fællesskabet, fordi medarbejderne netop får det ansvar alene, som i modellen er delt mellem medarbejdere og medlemmer ${ }^{34}$. En ansvarsfordeling der understøtter ligeværdigheden som vægtes højt i Klubhusene. Medarbejderen får en arbejdsfordeler/opgaveopfinder rolle i stedet for at arbejde side om side med medlemmerne om driften af Enheden. Eller medarbejderen bliver 'eksperten', der har overblikket, svarer på spørgsmål og tager beslutninger i steder for at være en, der arbejder med dagens opgaver sammen med/ved siden af medlemmerne.

\section{Medarbejderprofessionalisme i Klubhusene - Om støtte, kontinuitet og kollegialitet}

Som jeg fremanalyserede ovenfor, spiller kontinuitet i livet i Klubhusene en væsentlig rolle for medlemmernes mulighed for at udleve deres arbejdsmotivation. Medlemmerne og medarbejderne bidrager via deres gentagelse af Dagsprogrammet til at opretholde kontinuiteten. Mangel på kontinuitet ændrer medarbejderrollen og det har konsekvenser for muligheden for at få fællesskabet til at fungere som et driftsfællesskab, hvor medarbejdere og medlemmer med deres arbejdsevner bidrager ligeværdigt til Klubhusets drift. Her i afsnittet ser jeg på medarbejdernes rolle som medarbejdere. Det vil sige at jeg 'træder ind' og undersøger det professionelle arbejde nærmere og uddyber hvad medarbejderne gør på 'deres side' af samspillet.

Udgangspunktet for analysen er en nysgerrighed efter at forstå 'motivation' i Klubhusregi nærmere. Derfor arbejdede jeg med at forstå, hvordan motivation kan forstås med fokus på klubhussamvær mellem

\footnotetext{
34 "Klubhusets medarbejderstab er tilstrækkelig til at engagere medlemmerne i klubhusarbejdet, men ikke større end at ansvarsområderne kun kan varetages med medlemsdeltagelse"; (9) "Ansvaret for husets drift ligger hos medarbejdere og medlemmer" (11); " Dagsprogrammet inddrager medlemmer og medarbejdere sammen i klubhusets drift" (15). Uddrag af Standard nr. 9, 11 \& 15. (I: Retningslinjer for klubhuse).
} 
medarbejdere og medlemmer. Men som udefrakommende var det i første omgang svært, for medlemmerne fremstår først og fremmest som meget motiverede, fordi de så veloplag melder ind og tager ansvar i Enhedernes og husenes opgaver, de hjælper hinanden og passer roligt og med værdighed de opgaver, de påtager sig. "Hvis jeg bliver hurtigt færdig med referatet, tager jeg lige noget rengøring" lyder det for eksempel i Kontoret i Fontæne Huset i Århus. For den udefrakommende feltarbejder virker det som om 'det hele går af sig selv'.

I hverdagslivet gebærder medarbejdere og medlemmer sig altså som ligeværdige parter i det daglige arbejde og sociale liv, som hverdagen er organiseret i. Også derfor gav det anledning til 'hovedbrud' at få en fornemmelse af medarbejdernes professionelle opgave $i$ forhold til medlemmerne. Især i starten, hvor jeg blev indfanget i den høje grad af kontinuitet.

Jeg fandt ud af, at arbejdsmotivation (som jeg har behandlet ovenfor), kan adskilles analytisk fra motivation set som medarbejdernes professionelle opgave i forhold til medlemmerne. En medarbejder forklarer om deres faglighed, at "Jeg synes vores rolle er meget klar. At vi hele tiden motiverer til at vare del af fxllesskabet. Det vi finder ud af, er, hvor meget vi skal motivere til at være del af fxllesskabet, og hoor meget vi skal lade medlemmernes egen motivation være det styrende" (Fie, medarbejder FH Å).

Det er medarbejdernes motivationsarbejde, jeg adskiller analytisk fra det individuelle medlems arbejdsmotivationen som det individuelle medlem bærer ind $\mathrm{i}$ Klubhuset. Som sådan har motivation under en vinkel om medarbejderprofessionalisme fællesskabet som omdrejningspunkt. "Når man er medlem her, fär man ikke sådan samtaler med medarbejderne, man fär mere et personligt udbytte ved, at man er med $i$ opgaverne $i$ Enheden og samarbejder om det, der skal laves ", forklarer Barbro (medarbejder FH Å) en førstegangsbesøgende.

Min analyse er, at medlemmet på vej ind søger struktur (organiseringen i Dagsprogrammet) for at dæmpe de symptomer eller konsekvenser (indre kaos eller mangel på indhold i tilværelsen fortælles det for eksempel), som deres sindslidelse indebærer. Som Harald (medlem FH K) sagde, "Det er ikke så godt at komme et sted og opleve en grad af kaos $i$ stedet for en grad af struktur, når man har det sådan lidt dårligt - Eller hvis det er nemt at finde ud af, hoad det er for nogle opgaver, man skal lave, så er det også godt".

Det arbejde det indebærer at strukturere sig selv sammen med strukturen i huset - altså bruge den ydre struktur til at få struktur med sig selv, kan medarbejderen (og etablerede medlemmer) støtte via fastholdelse af organiseringen. Det vil sige, at man gør tydeligt, at man er der sammen for at lave overskuelige, gennemskuelige opgaver, der kan færdiggøres helt af den enkelte med den nødvendige støtte, sidemandsoplæring, samarbejde mv. Det 
fremgår for eksempel af tavlerne, tavlegennemgangen, beskrivelsen af opgaver, tidsinddelinger mv.

Som Eigil (medarbejder FH K) siger, "Nu ved jeg, hvordan jeg gør - Hun [en førstegangsbesøgende, der er kommet en halv time for tidligt, og som han vurderer ud fra deres telefonsamtale vil opleve det for overvældende at blive involveret i køkkenet med det samme, men som på den anden side må opleve sig nyttig i stedet for som tilskuer indtil selve introduktionsarrangementet begynder $\mathrm{AH}]$ kan være med til at dxkke bord til os alle sammen. Hun kan se hvad opgaven går ud på, for jeg stiller alle tingene frem, og så kan vi gå og dække bordet sammen og snakke".

Knud (medarbejder FH Å) spørger Alexander (besøgende medlem fra Jelling): "Kan Klubhusets strukturerede Dagsprogram afløse behovet for ansvarstagende hjælpere så som terapeuter, som du taler om?". Og som Fiona (medlem FH Å) siger, "Jeg har det rigtig svært med struktur, men jeg vil have rigtig god fordel af det, tror jeg"(G 4.6.2010). Den struktur kan medlemmerne på vej ind 'fă', når de arbejder med at udleve stabilitet i deres medlemskab (for eksempel med at komme til enhedsmøderne, komme på de aftalte dage, følge organiseringen i arbejde og pauser og påtage sig opgaver i Enheden).

$\rightarrow$ Der er flere nye medlemmer i Kontoret. De har gennemgået ca. halvdelen af deres to ugers/10 timers introduktionsperiode. På enhedsmødet spørger Frans (MA), hvordan de synes, det går indtil videre. Veronica (M) svarer, at hun synes det går godt, "men jeg glæder mig, til det her er overstået, så jeg kan komme rigtigt i gang"; Frans: "Jamen du er i gang"; Veronica: "Jamen det er kun et par timer"; Frans: "Du må komme her alt det du vil nu"; Veronica: "Neej, nu følger jeg det her program". Frans nikker ok, men gennem den følgende uge støtter han Veronica i hendes motivation på forskellige måder: Da hun vil gå før frokost en dag, siger Frans: "Du behøver ikke at gå, jeg siger det gerne igen, at du gerne må blive her og bestille noget mere". Han foreslår opgaver: "Kan du skrive et brev vi kan lægge ved bladet?". Det vil hun gerne. Han samarbejder med hende ved at de finder på gode formuleringer sammen. Han foreslår, at hun kigger på en opgave sammen med nogle af de andre nye, som de kan løse i fællesskab, og han etablerer kontakt til et 'gammelt' medlem, som kan sætte hende ind i en bestemt arbejdsgang. Han gør opmærksom på pauser og mødetidspunkter, så alle opgaverne struktureres i forhold til Dagsprogrammet, og han viser opgaver, hun selv kan gå over og finde, når hun mangler noget at lave. Hun følger opmærksomt 'det hele' $\leftarrow$ (Feltsekvens FH K tirsdag den 13.april-fredag den 16.april 2010 ) 
Man kan sige, at medarbejderprofessionalisme gøres ved, at imødekomme medlemmets egen motivation. I feltsekvensen understøtter medarbejderen gennem flere dage, medlemmets deltagelsesmuligheder ud fra hendes udtrykte arbejdsmotivation (hun siger, at hun glæder sig til at komme rigtigt i gang). I Dagsprogrammet, som organiserer deres hverdag, er medarbejderen opmærksom på opgaver, han kan se, medlemmet kan påtage sig alene eller sammen med andre, han spørger, hvordan det går undervejs, arbejde sammen med hende, og gør opmærksom på pauser.

Medlemmet har det ikke så godt endnu, men hun kan bruge den struktur Fountain House tilbyder - den kan afløse nogle af de problemer, hun har: "Jeg tror godt vi alle sammen bare vil have noget indhold $i$ tilvxrelsen og noget struktur" supplerer Veronica og et andet nyt medlem hinanden, da jeg spørger, hvordan det går med at blive medlemmer i Fountain House.

Det inde-forpligtede medlem søger procesarbejdsmuligheden (med egne processer/egen rehabilitering) $i$ det (nu) strukturerede liv, der nærmest 'automatisk' leves og reproduceres i og med Dagsprogrammet.

Det støttes af det menneskelige ligeværd med 'alle de andre', hvor medlemmet, på sin måde, er fuldgyldigt nyttigt for fællesskabets bedste. "Det er ligesom man vokser, fordi nogen siger, at det var en god ret vi havde lavet eller en flot avis. Det er dejligt, at vi arbejder for hinanden og man fär øjeblikkelig anerkendelse", opsumerer en sosu-praktikant (FH $\AA$ ) et punkt i et gruppearbejde på en temadag. Jes (medlem FH $\AA$ ) fortæller "Der er også det ved det her sted, at der ikke er noget arbejde, der er bedre end andet. Vi deles om det - både rengøringen og det at sidde ved en computer, og hoad vi nu ellers laver"(G1.6.2010).

Det inde-forpligtede medlem er kontinuitetsbærer, fordi han/hun selv har så stort behov for kontinuiteten og derfor nøje følger den. Gunhild (medlem FH $\AA)$ forklarer: "Jeg har faste opgaver, det har jeg haft alle årene. Fontæne Huset giver mig tryghed, fordi jeg ved, hvad jeg skal; men det bliver alligevel aldrig ensformigt. Den balance er der". Det inde-forpligtede medlem deltager i fællesskabskontinuitetsopretholdende opgaver. Det er for eksempel i form af henvisninger til at overholde organiseringen eller med sidemandsoplæring, når der er basis herfor.

En af dagene i køkkenet følger jeg Gunhild i hendes arbejde, og hun støtter og hjælper mig hele tiden ved at fortælle, hvad der sker nu, og hvordan vi kan fordele os i samarbejdet om opgaverne. Hun spørger også hele tiden, hvad jeg synes. Jeg noterer: "I dag har jeg været rigtig 'ny i huset', Gunhild er erfaren og har givet mig hjælp, sat mig i gang og vist mig til rette, vi har samarbejdet, og hun har bedt mig om hjælp. Vi sagde 'tak for samarbejdet', da hun skulle hjem".

Strukturen kan også tages med hjem af det inde-forpligtede medlem. August og Bjarne (medlemmer FH $\AA$ ) fortæller, at: "Men jeg bruger for eksempel 
også den struktur, jeg får herfra derhjemme. Så tager jeg det sådan $i$ etaper. Den indarbejder jeg her. Det er lige som om, man er vant til at have struktur, og så planlægger man selv og bruger den, fordi man er vant til det. For eksempel når jeg laver mad $i$ Bofxllesskabet, og der skal handles ind og alt det der, altså den arbejdsstruktur synes jeg, man kan bruge"(G 1.6.2010); "Jeg kan godt genkende det med, at jeg siger til mig selv: 'Du tager et lille stykke hver dag' - Jeg gør et lille stykke hver dag. Så det der med at dele det op i stedet for hois man skulle tre timer om lordagen, det ville jeg ikke få gjort - men sådan lidt hver dag, ja"(G 1.6.2010).

$\rightarrow$ Den dag jeg starter mine feltstudier i Fontæne Huset i Århus, er August (M) referent på Husmødet. I løbet af dagen får han flere rosende kommentarer med på vejen, om sit mod på udfordringen. På vej til bussen hjem fortæller han mig, at han blev referent 'lidt' ved en fejl. Han var kommet til at sige referent i stedet for ordstyrer (han fortæller, at han har begge funktioner, som noget han vil arbejde med i sin handlingsplan ${ }^{35}$ ). Han bruges som eksempel på et møde senere på ugen, og nikker bekræftende til den analyse af situationen, en medarbejder laver, og i de kommende dage taler han med flere om situationen. Anker (MA) spørger på et enhedsmøde, hvordan August synes, det gik. August er godt tilfreds: "Jeg kan godt finde på at gøre det en anden gang", konkluderer han. Anker spørger, om han fik tilbudt hjælp. "Jo, jeg fik tilbud om hjælp, og jeg tog også imod noget hjælp til at varetage funktionen", svarer August. Da referatet kommer renskrevet tilbage fra Kontorenheden, spørger Anker, hvordan det var at være i centrum, for det kan jo også være en udfordring, at sidde for enden af bordet, hvor alle kan se en. Men August tænkte ikke sådan: "Nej, jeg tænkte på at løse opgaven og få det vigtigste skrevet ned på papiret, det var det, jeg havde travlt med", siger han $\leftarrow$ (Feltsekvens FH $\AA$ onsdag den 10.marts - tirsdag den 23. marts 2010)

Medarbejderprofessionalisme er altså også ved som medarbejder at trække sig og være temmelig ligeværdig kollega med det inde-forpligtede medlem med den gensidige viden, at medlemmet har 'ting og sager i gang' ved sin deltagelsesform, hvor han/hun kender organiseringen og opgaverne så godt, at han/hun kan få øje på 'delopgaver' i driften af huset, som understøtter

\footnotetext{
${ }^{35}$ I Fontæne Huset i Århus arbejder man med handlingsplaner (jf. Århus Kommune), i Fountain House København hedder det Medlems Udviklings Samtaler, hvortil der gøres notater på et forud konstrueret skema. I Kildehuset i Nørresundby har man ingen af delene, fordi det at have nedskrevne planer minder om psykiatrien. "Der er ingen aftaler, kontrakter, skemaer eller regler, som er udarbejdet med henblik på at tvinge medlemmerne til at deltage"(3); "Medlemmerne deltager efter eget valg i udarbejdelsen af skrivelser, der afspejler deres deltagelse $i$ Klubhuset. Alle sådanne skrivelser skal underskrives af både medlem og medarbejder" (5). Uddrag af Standard nr. 3 \& 5. (I: Retningslinjer for klubhuse).
} 
hans/hendes processer. Det vil sige det medlemmet gerne vil kunne. Som Betty (medarbejder FH Å) siger: "August, jeg er da sikker på, at det med at være referent $i$ dag, det betød noget for dig; men det er din proces".

Muligheden for at se og tage udfordringer ligger i Klubhusorganiseringen af varetagelsesmulighed af opgaver, hvor opgaverne er åbenlyse, frit og lige tilgængelige for alle; men det afhænger af det enkelte medlem om/hvornår opgaven er relevant. Medarbejderne støtter med kommentarer og spørgsmål, som understøtter procesbevidstheden (at medlemmet er i gang med 'noget'), og de hjælper med at gøre tydeligt, hvilke faktorer der kan arbejdes med eller reflekteres over i forhold til opgaven (for eksempel at komme til at befinde sig $\mathrm{i}$ centrum af beslutningstagningen ved at have referentrollen).

På en video jeg ser om Fontæne Huset, siger en medarbejder, at de ikke tænker det sådan, at de kan lære medlemmerne noget - medlemmerne har andre erfaringer end medarbejderne, men qua deres fagligheder og Klubhusmodellen, kan de tilbyde rammer, som er befordrende for de processer (for eksempel med at få det bedre, komme op og af sted om morgnen, eller varetage forskellige jobfunktioner) som medlemmerne er i gang med. August uddyber på et møde, hvor de drøfter forholdet mellem Klubhusmodellen og Århus Kommunes recovery tilgang, at han som medlem af Fontæne Huset oplever, at det at indgå i husets drift indebærer sidegevinster: "Man får noget andet $u d$ af det, end lige det, det er, at stå og tapetsere. Jeg mener sidegevinster. Og det er derfor, vi alle sammen er her" (August, medlem FH A).

Medlemmet 'på vej ud' (eller som kunne være det, hvis det var tvingende nødvendigt ${ }^{36}$ ) arbejder med enhedsspecifikke jobudfordringer, der ligner 'det derude'.

Der arbejdes i ligeværdig kollegialitet med medarbejderne om Enhedens mangeartede opgaver, og med stort overskud til at varetage fællesskabskontinuitetsopretholdende opgaver (sidemandsoplæring, tonen i huset, arbejde på tværs og ud af huset mv.). "Der er mange, der har sagt, om jeg ikke skal ud $i$ et almindeligt job; men jeg har det godt med det her, for jeg kan gøre alt det, medarbejderne gør efterhånden. Så der er egentlig slet ikke forskel. Men alligevel det er uden at stå ansigt til ansigt med det, jeg ikke kan klare, som er det der med bundlinjeansvar. Derfor bliver jeg her. I hvert fald foreløbigt" (Olav, medlem FH K).

$\rightarrow$ Gertrud (M) viser mig den arbejdsopgave, hun sidder med. Det er en omfattende opgave, som hun allerede har arbejdet med i flere uger. Deadline nærmer sig. Opgaven involverer arbejde med Klubhusmodellen, og hendes invitation til samtale giver anledning til en snak. Hun fortæller, at man nemt kan blive involveret i det hele, både lokalt, nationalt og helt ud på det internationale plan: "Hvis man altså har lyst og orker det", siger

36 "Jeg er egentlig erklæret rask" (Sigfred, medlem FH K) 
hun. Jeg kan forestille mig, at der kan vise sig mange spændende opgaver, når man lærer stedet at kende, siger jeg. Gertrud: "Det er en balance man må finde, mellem at involvere sig $i$ det man synes er spxndende, men ikke mere end man kan overkomme ". AH: "Det kan man vel også få hjxlp til af medarbejderne?". Gertrud: "Jo, men vi hjælper jo også meget hinanden. Man bliver jo mest motiveret af det fxllesskab, man bliver del af her. Det er det, der er det tiltrækkende. Så kommer alle mulighederne til som noget, der åbner sig, når man bliver del af huset. Så er der også tit nogen, der roser os, og vi er gode til at rose hinanden". Gertrud fortæller, at det svære er, at opgaven er så tidskrævende, så hun kan godt have fornemmelse af, at svigte i forhold til den daglige drift af Enheden. Men via en snak med en medarbejder, har hun fundet ud af, at det er en unødig bekymring $\leftarrow$ (Feltsekvens $\mathrm{FH} \AA$ tirsdag den 16.marts 2010)

Medarbejderprofessionalisme er dermed også at være kollegial 'rammeopretholder' sammen med medlemmerne. Altså stå inde for kontinuiteten sammen med medlemmerne i et samspil, hvor der egentlig ikke er forskel på funktionen medarbejder og medlem i husets drift - for nogen af parterne.

Det er oplevelsen af, at blive motiveret via det at være nyttig ved at bidrage med sin enhedsspecifikke faglige indsats - for eksempel kontorarbejde, som Gertrud giver udtryk for. Den store formidlingsopgave hun har påtaget sig, er hun fuldt ud i stand til at løse rent fagligt. Det ved medarbejderne, og de overlader det til hende at arbejde med det, 'den tid det tager'. Når hun har brug for hjælp, er det sådan set ikke til selve opgaven (med brug af pc, formulering, kommunikation med samarbejdspartnere uden for huset, design mv.), men til at indpasse opgaven til fællesskabets bedste. Det er det, der kommer i spil som et relevant arbejdsmæssigt spørgsmål, ved at hun indgår i driften. En udfordring der dukker op qua medlemmets måde at indgå på nu. Den side af det drøfter hun kollegialt med medarbejderne, som støtter hende i, at hun bidrager væsentligt med opgaven og dermed ikke 'forsømmer' noget i den daglige drift, som hun på grund af opgavens omfang deltager mindre $i$, end hun plejer.

Det er en type medarbejderprofessionalisme og kollegialitet som strækker sig ud over det daglige medlemskab ved at skabe drøftelsesmulighed af de spørgsmål der dukker op, når man er 'derude' efter FH: Barbro (medarbejder FH Å) forklarer, "Vi havde en jobgruppemiddagi7, og der var en, der spurgte, 'Hvad så

\footnotetext{
${ }^{37}$ Jobgruppemiddagen er et månedligt arrangement i FH $\AA$, hvor tidligere medlemmer som er i job nu, medlemmer i praktik, OA eller anden arbejdsmæssig sammenhæng uden for Klubhuset, har mulighed for at komme i Klubhuset til et socialt arrangement sammen med nuværende medarbejdere og medlemmer og drøfte job spørgsmål (mv.).
} 
når det bliver 'hverdagsagtigt', jobbet. Hvordan holder man så gejsten oppe?'. Det havde vi sådan en god dreftelse af, at 'så bider man sammen og fortsætter, og at man selv er ansvarlig for at finde ud af, hvordan arbejdsindholdet kan opleves som spændende med sin egen indstilling". Det bliver altså muligt at gøre et emne til et emne, der kan drøftes kollegialt, fordi det dukker op af medlemmernes egne erfaringer.

På baggrund af analysen om medlemmet på vej ind, det inde-forpligtede medlem og medlemmet der kunne være på vej ud, hvis det var tvingende nødvendigt, kan man sige, at medarbejdernes faglige professionalitet $i$ Klubhusfællesskabet kan forstås som noget, der sker mellem medlemmer og medarbejdere i ligeværdigt Klubhussamspil i form af støtte, kontinuitet og kollegialitet indenfor den ramme klubhusmodellen stiller op for samspil ${ }^{38}$ og den måde den leves af medlemmer og medarbejdere i hverdagens samspil gennem gentagelse af organiseringen for arbejde og samvær.

\section{The Fountain House Way - Afslutning}

På den ene side arbejder medlemmerne inde i den ramme som Klubhusene er med den model for rehabilitering, der ligger i (1) at føle sig nyttig fordi man kan gøre en arbejdsmæssig indsats ved at udvirke sin arbejdsmotivation (komme og bruge sin arbejdsevne), (2) at være i ligeværdighedsforhold med andre mennesker (medlemmer og medarbejdere), hvor man arbejder side om side, ting tager den tid de tager, med mulighed for støtte fra medarbejderne som er anderledes end at være bruger af et værested eller klient/patient i en behandlingssammenhæng, og (3) det som muligheden for kontinuitet giver, når modellen smitter af (hvor medlemmet gør sit medlemskab (og dermed sit liv) stabilt ved at deltage $i$ at reproducere Klubhusets organisering og samværsformer.

Disse tre aspekter vedrører individuelle rehabiliteringsmuligheder for det enkelte medlem. Tanken er ikke, at medarbejderne kan lære medlemmerne noget, men at Klubhuset er rammen om/for rehabilitering: "Vi kan ikke lære nogen noget, processerne er nogens egne. Men vi kan stille rammen til rådighed og stille op, så der er nogen at sparre med. Jeg synes opgaven og indholdet er meget tydeligt $i$ forhold til den enkeltes proces" forklarer Betty (medarbejder FH Å). Hun siger, at de som medarbejdere "giver stotte til den enkeltes 'jeg' på den måde, vi er sammen på - For eksempel ligesom når August er referent. Alle oplever i hver deres proces, hoad

\footnotetext{
38 "Alle klubhusmøder er åbne for både medlemmer og medarbejdere" (8); "Ansvaret for husets drift ligger hos medarbejdere og medlemmer" (19); "Alle klubhusets lokaler er tilgængelige for medlemmer og medarbejdere"(14); "Dagsprogrammet inddrager medlemmer og medarbejdere sammen $i$ klubhusets drift"(15); "Medlemmerne har mulighed for at deltage i alle klubhusets aktiviteter" (20). Uddrag af Standard nr. 8, 19, 14,15 \& 20. (I: Retningslinjer for klubhuse).
} 
der betyder noget - At de kom og tog en beslutning om noget. Der er ingen, der bliver presset til noget, men man bliver opfordret, og så er rammerne der for, at man kan tage beslutningen. Jeg er sikker på, at det betød noget for August; men det er hans proces".

Som Alexander (besøgende medlem fra Klubhuse i Jelling) giver udtryk for på min første feltarbejdsdag i Fontæne Huset i Århus: "Det hele udspiller sig som arbejdsorganisering. Men dem der er her, vi ser det ikke kun som et stykke enhedsarbejde [altså for eksempel at renskrive referater, skrælle kartofler, støvsuge, male en væg AH]. Nej, man forholder sig til det hele - hvordan det hele forholder sig til den proces vak fra sygdom, som man er $i$ ". August (medlem FF A) supplerer: "Man får noget andet ud af det, end lige det, det er, at stå og tapetsere. Jeg mener sidegevinster. $O g$ det er derfor vil alle sammen er her". Alexander svarer: "Arbejdet går fint og der er masser af struktur; men hvis man går ind i en åben dialog om følelser så finder man sideløbende ud af, hoad der skal arbejdes med ved siden af den pæne arbejdsorganisering, tror jeg".

På den anden side er der også en stærk fællesskabsside ved den måde modellens rehabiliteringstanke leves i hverdagen i Klubhusene. For det er præcist via medlemmets bidrag og deltagelse i Klubhusets daglige drift, at der tænkes at foregå rehabilitering. Som Betty (medarbejder FH A) siger, "Jeg ser aldrig sådan en forherligelse af den enkelte her - af en enkeltpersons projekt".

Det er gennem deltagelse og bidrag i og til fællesskabet, at Klubhusene 'lover' nye muligheder (der er anderledes end psykiatriens behandlingstilbud) for det individuelle medlems rehabilitering. "Når man er medlem her, får man ikke sådan samtaler med medarbejderne, man fär mere et personligt udbytte ved, at man er med $i$ opgaverne $i$ Enheden og samarbejder om det, der skal laves ", (Barbro, medarbejder FH Å). "Kernen $i$ det hele er, at der er øjeblikkelig afregning: Vi laver mad, og det er for dem, der kommer. Så det det handler om, er, at vi gør det for hinanden. Det er det, der giver mening" (Knud, medarbejder FH Å). Som Asta (medlem FH Å) gjorde opmærksom på tidligere, så er Klubhusene primære aktiviteter centreret om arbejdet, som man laver sammen/for/med hinanden.

Inde i hverdagslivet i Klubhusene er der altså ikke noget modsætningsforhold mellem på den ene side det enkelte medlems arbejde med sin individuelle rehabilitering og på den anden side modellens fokus på fællesskab og samarbejde. Det er det, der sideløbende hele tiden foregår i hverdagslivets samspil. Andreas (medlem FH Å) fortæller netop, at han kan lide Fontæne Huset fordi: "Det betyder meget, at der er flere, for det er rart at arbejde sammen med en. For eksempel Kalle, for så snakker man jo også om, hoad der er sket siden sidst og man snakker jo om, hoilken gryde, der skal bruges og hoor mange dåser flåede tomater der skal $i^{\prime \prime}$.

Det er medlemskab på The Fountain House Way, at medlemmerne har processer, de arbejder med, med sig ind i Klubhusene sammen med den arbejdsmotivation de også bærer ind (som gør Klubhuset til noget for dem). 
Man kan sige, at medlemmerne kommer i Klubhusene med hver deres motivation til at (komme til at) kunne det de gerne vil. Det kan være konkrete ønsker om at genoptræne specifikke ting i forhold til arbejdsevne: "Jeg vil godt være medlem, fordi jeg vil godt tilbage og passe sådan et kontorjob med reception igen, det er derfor, jeg har valgt kontoret. Kan jeg lære det med omstilling her? " (ny på førstegangsbesøg, FH Å). Men det kan også være, at "Det at være del af noget her, er håb nok $i$ sig selv. Det at snakke for meget om håb, det er alt for stort. Håb det har vi jo ved at være del af det her" forklarer to medlemmer (FH Å) tålmodigt en konsulent på besøg fra Århus Kommune.

Medlemmernes processer leves via det forpligtede medlemskab, fordi medlemmerne viser/udlever klarhed til at indgå med deres arbejdsmotivation og den arbejdsevne de har i det seriøse arbejds- og samværsfællesskab de via Dagsprogrammet udfordrer sig og udfordres i.

Processerne er medlemmernes egne, og de foregår så at sige mens de har travlt med at indgå i fællesskabet ${ }^{39}$ og gennem den motivation som de dels selv kommer med, dels mødes med af medarbejderne. Medarbejderne i Klubhusene ved, at en arbejdsmotivation ikke nødvendigvis er det samme som at kunne - det er gerne at ville.

Klubhuset, med medarbejdernes støtte, deres stabilitetsopretholdende praksis (værne om Dagsprogrammet så medlemmet kan varetage sin proces), og den kollegiale måde at forstå sig i forhold til medlemmerne, er den ramme, der stilles til rådighed for de processer, medlemmerne kommer med for deres rehabilitering, som medarbejderen ikke (nødvendigvis) kender i detaljer, men efterhånden nok har en ide om, selv om de ikke snakker om sygdom og diagnose. Som Mads (medarbejder FH K) forklarer, "Jamen da der ikke var andre medlemmer på det tidspunkt, så gik vi [han og et nyt medlem $\mathrm{AH}$ ] ned og malede $i$ kælderen og så varede det ikke længe, så fik vi hinandens livshistorier".

I Handleplanssamtaler og Medlems Udviklings Samtaler tales der også om, hvordan medlemmet vil bruge Klubhuset for at få det bedst mulige udbytte af det et Fontæne Klubhus kan. Så kan medarbejderen udfordre eller prikke til medlemmet og samtale om, hvordan medlemmet bedre bruger sin tid i Klubhuset gennem deltagelse og samarbejde i fællesskabet om husenes drift. Uanset om det i konkret hverdagspraksis drejer sig om at samarbejde om at lave frokost til alle, eller skrive det referat rent, som et andet medlem tog på sig at tage på det foregående Husmøde.

${ }^{39}$ Fællesskabet er 'det antropologiske' ved Klubhusene. Det er synligt for en deltagende observatør på feltstudier, at de gør fællesskab gennem de måder de udlever klubhuspraksis. Hvad den enkeltes processer går ud på er derimod skjult; men via analyse af medarbejdernes og medlemmernes samspil i ord og handling er det alligevel muligt at sige, at der er individuelle processer i spil. 
$\rightarrow$ Der har været fordelingsmøde på Kontoret. Nu har der været stille bortset fra tastelyde et stykke tid. Buster (M), som er relativt ny i huset, går gennem rummet med et print af 'Dagens Avis' til i morgen, som han netop er færdig med. Betty (MA) går gennem rummet i modsat retning. "Den ligner en sodavandsis med de klare farver", kommenterer hun, da de mødes. Så har de passeret hinanden. Buster kigger på Avisen og siger "Nåå, ja" - så er han inde i kopirummet og lidt efter går han ud af Kontoret. Han er væk et øjeblik. Bagefter tager han blokken med opgaver, som ligger på det centrale kontorbord. Han står med blokken i hånden midt i rummet. Betty snakker i telefon i 'det lille kontorrum' inde bagved. Da hun kommer ud, viser han hende blokken og spørger, om en af opgaverne er noget, han kan gøre. Det er det. Det er et referat til renskrift, som Betty finder frem og rækker ham. Der er et par kommentarer, han skal være opmærksom på, minder hun om. Så går Buster hen til en computer. Lidt efter kalder Betty på Buster: "Så er det pausetid Buster". Efter pausen i Kantinen er der tastelyde i Kontoret igen. Så kommer Buster ud og spørger Betty om noget med et bilag til referatet. Men hun skal lige lave noget færdigt, før hun har tid til at svare. Da hun er ved at være færdig, spørger hun "Var det Shawarma, vi fik i fredags". Buster bekræfter, mens han stadig står og venter. Så er hun færdig. Jo, bilaget skal lægges ved renskriften. Hun har et par bemærkninger til referatet, som han fører ind. Betty går også ind og taster videre på sin opgave. Men nu henvender hun sig til ham, imens hun arbejder og fortæller, hvor mange kopier han skal lave og hvilke dueslag referatet skal i. Da Buster er færdig tager han kopier og går ud i receptionen; men han kommer tilbage og stiller sig til at vente på at Betty har tid: Han spørger hende om 'det med dueslagene'. Hun forklarer igen, men tilføjer "Skal jeg lige gå med, så kan jeg også lige vise dig det". "Ja tak" siger Buster. De fordeler kopierne af referatet i de relevante dueslag sammen. "Nu er det snart frokost. Hvad tid skal du hjem i dag?" spørger Betty. Buster fortæller, at han vil spise med i dag. Betty viser Buster et prøveprint til 'Fontæne $\mathrm{Nyt}^{\prime 40}$ og fortæller, hvad hun har fået lavet i dag. "Nåå, men så er du jo tæt på færdig", kommenterer Buster. Så er det frokost. Klokken er $12.00 \leftarrow$ (Feltsekvens FH Å mandag den 31. maj 2010)

Som udgangspunkt er medlemmet Buster arbejdsmotiveret. Han byder ind på en opgave på enhedsmødet og løser den: Det er 'Dagens avis' som skal skrives, sættes op, printes og fordeles. Den opgave kender han 'ud og ind' (det vil sige alle facetter af arbejdsprocessen fra design og indhold til tryk og fordeling). I morgen bliver den læst højt på morgenkaffemødet. Han har tydeligvis bidraget

${ }^{40}$ Fontæne Nyt er FH Å månedsblad som Kontoret står for. 
med en opgave som er til fællesskabets bedste (hjælper andre med at strukturere deres dag, fordi de kan få overblik og følge med i, hvad der sker).

Efter opgaven med Dagens Avis er afsluttet, søger Buster en ny arbejdsopgave. Han er endnu ikke så 'gammel i gårde' og kender arbejdsgangene så godt, at han helt 'tager selv'. Men han ved, hvor han skal søge: Han finder blokken med resterende opgaver frem og udser sig en opgave, han kunne tænke sig at løse. Han henvender sig til medarbejderen for at finde ud af, om det nu stadig er en ledig arbejdsopgave. Derved udlever han sin arbejdsmotiverethed i fællesskabet og viser, at han er klar til at påtage sig opgaver og bruge sin arbejdsevne i driften af huset som er til fællesskabets bedste. Det er en ledig opgave. Medarbejderen støtter med det medlemmet 'kontorfagligt' har brug for at vide for at kunne gennemføre opgaven.

Medlemmet deltager og bidrager ved sin tilmelding og gennemførelse af arbejdsopgaver og deltagelse i Dagsprogrammet (enhedsarbejde i vekselvirkning med pauser) til kontinuiteten i Klubhuset. Måske har han selv gavn af den strukturering det er at påtage sig og følge opgaver til dørs. Det kan vi ikke vide - det er hans proces, hvad han bruger det til. Men ved at deltage reproducerer han sammen med de andre medlemmer og medarbejderne Dagsprogrammet og dermed kontinuiteten for sig selv og os andre (medlemmet foretager sig præcist den slags aktiviteter, som rummet/Kontoret og huset $i$ indretning og omgangsformer sender signal om er relevante).

Han henvender sig til medarbejderen om hjælp. Medarbejderen siger 'nej'. Hendes nej kan forstås pædagogisk som en hjælp til medlemmets processer, hvis det er noget af det, hun har fornemmelse af, at han arbejder med (for eksempel at et nej er et nej lige nu til det han spørger om, ikke til hele ham som person for altid), eller det kan forstås som en understregning af ligeværdigheden: De arbejder hver især med vigtige opgaver på lige fod i deres arbejdsfællesskab med driften af Enheden og huset. Hvis medarbejderen stiller sig til åben rådighed, og slipper alt hvad hun har i hænderne med det samme, er de ikke ligeværdige kolleger. Så har han, i arbejdsfællesskabet, mere brug for hende end omvendt. Når medarbejderen 'tøver' er driften af huset i fokus.

De snakker om hverdagsting: Hvad det de fik at spise i fredags hedder, da de hentede mad 'udefra' til deres enhedsdag. Det ved Buster mere om end Betty. Og hun fortæller ham, hvor langt hun er med sin arbejdsopgave (bladet), som han sætter sig ind, i at hun dermed næsten har gjort færdigt.

Medarbejderen supplerer med sin henvendelse til medlemmet om ting, hun er kommet i tanke om skal med i referatet, sådan at opgaven ved fælles hjælp bliver løst bedst muligt. Der er en effektiv stemning i deres arbejdsomme fællesskab. Der er enhedsopgave-løsning på tapetet. Medlemmets arbejdsmotiverethed, som han kommer med, bliver mødt af medarbejderen med 'du kan' som undertekst. Det er ikke hans usikkerhed på opgaven, kiggen 
væk/ned i gulvet, 'dagsformen' som nok er lidt skidt, der er i fokus. Det er hans vilje til at påtage sig Enhedens opgaver og arbejde med det der kommer i spil derved.

I stedet for at give instruktioner om fordeling i dueslag som medarbejderen først går i gang med, vælger hun at løse fordelingsopgaven sammen med medlemmet. De er kolleger, men samtidig lærer han til næste gang, hvad 'gangen' i opgaven er, hvormed han i fremtiden kan påtage sig den med større selvstændighed, og måske med tiden oplære nyere medlemmer i opgaven.

Til slut skal de holde deres velfortjente frokostpause. Buster vil spise med i dag. Da klokken er 12 siger Betty at det er 'nu'. Dermed understreger hun, ligesom ved kaffetid kl. 11 strukturen, der bryder arbejdsomheden og minder om, at ud over at samarbejde og bruge sin arbejdsevne i Enheden, ligger der også en social træning, som Buster har taget hul på ved at fortælle, at i dag vil han spise med.

Socialpædagogik på The Fountain House Way, er måder at invitere til og møde samspil på, som befordrer medlemmets processer via deltagelses- og bidragsmuligheder til driften af Klubhuset og fællesskabets bedste. Som Fie (medarbejder FH Å) sagde, "Det vi finder ud af, er, hvor meget vi skal motivere til at være del af fællesskabet, og hvor meget vi skal lade medlemmets egen motivation være det styrende".

Det er en pædagogik med fællesskabet som omdrejningspunkt, hvori det enkelte medlem kan finde rum og mulighed til sit eget arbejde med sin rehabilitering.

Det er også en retning at forstå sindslidelse/psykisk sårbarhed i, som noget der kan overkommes, hvis medlemmet udvirker sit medlemskab indenfor de rammer et Klubhus stiller til rådighed. Medlemmerne skal komme og ville (udleve klar-hed) - og med støtte, stabilitet og kollegialitet (komme til at) kunne det de gerne vil.

Når medlemmerne udvirker deres medlemskab i samspil med de sociale og organisatoriske rammer et Klubhus er, gør de noget af deres rehabilitering det vil sige, de arbejder med det, de har brug for at opnå i deres liv i, med eller ud af en sindslidelse/psykisk sårbarhed, som netop et Fontæne Klubhus giver mulighed for. 


\section{Klub Fontana - Et Klubhus tilbud til unge med psykisk sårbarhed}

Klub Fontana eller "Klubben" eller "Fontana", som den omtales til daglig blandt medarbejderne og medlemmerne, skal præsenteres for sig selv, fordi den er en selvstændig del af Fountain House forstået som et særligt tilbud til unge med psykisk sårbarhed fra Københavns Kommune og omegn.

Når man befinder sig blandt medlemmerne og medarbejderne i Fontana fornemmes både stille eftertænksomhed og koncentration, og der høres dæmpet samtale, klirrende kopper i cafekøkkenet, musik fra computeren i hjørnet, sms-ringetoner, pige-fnis når 'hemmeligheder' deles med vennerne og højrøstede drengestemmer, når der kæmpes i backgammon.

Der høres også medarbejderstemmer med seriøst forklarende eller indlyttende røster: "Hvordan har du det med det?" (Else, medarbejder Klub Fontana), alvorlig stemmeføring, krav i stemmen og motiverende tonelejer: " $V i$ skal have fyldt op, vi har købt en masse ind - og der er også kopper til opvask ...[ingen rejser sig fra sofaen, hvorfra de unge medlemmer har fortalt, at 'Vi hænger ud'] ... I kan nok høre, jeg spørger jer om noget hjælp; jeg prøver at sætte jer i gang" (Lis, medarbejder Klub Fontana).

Der er 40-50 aktive medlemmer i Fontana - med aktiv menes medlemmer som frekventerer klubben mere end en enkelt eller få gange om måneden. For at sætte denne lidt 'vage' angivelse i perspektiv, anslår jeg, at jeg mødte i underkanten af 25 medlemmer i løbet af feltstudieugen i Fontana.

Klub Fontana optager unge mellem 18 og 25 år. De unge i Fontana er fortiden op til 28 år, eftersom medlemmerne ikke 'smides ud', når de fylder 25 år. Der sker nærmere en udslusning efterhånden, som de er klar. Nogle unge kommer bare kortvarigt i Fontana (uger eller måneder), mens andre er medlemmer omkring et par år (som anslås at være varigheden af de længste medlemskaber), før de på den ene eller den anden måde bevæger sig væk eller vokser fra Klubbens aktiviteter, udfordringer, pædagogiske tilbud og ungegruppe.

Når de unge forlader Klubben, fortsætter nogle i et andet af Fountain House særlige tilbud kaldet Bogstøtten. Bogstøtten er et tilbud til studerende med psykisk sårbarhed. For få medlemmers vedkommende overgår de til 'selve' Fountain House. Men medarbejderne fortæller, at hovedparten af de unge rykker helt ud af Fountain House, når de forlader Klub Fontana. Men medlemskabet hører ikke nødvendigvis sådan op lige med et. Mens jeg var på feltstudier, vender en ung, som er gået i gang med en ungdomsuddannelse tilbage og spørger, om han må deltage i Klubbens samvær og aktiviteter en enkelt dag ugentligt - for, som han siger, "Min Play Station er nede, og jeg forstår, at det er sådan, at I laver nogle andre ting end at hænge ud herinde nu" (Asbjørn, medlem Klub Fontana). 
Medlemskab følger altså den enkeltes behov for tilhør over tid, forudsat at det er det rigtige: "Vi skal overveje, hvad formålet er nu - altså om du går to skridt tilbage, når du nu er gået videre ... vi laver en aftale, og så kan vi tage det op på en tre måneders samtale [Medlems Udviklings Samtale (MUS) AH] om det er det rigtige" (Lis, medarbejder Klub Fontana).

Mens jeg var på feltstudier i Klub Fontana, var medarbejderne i gang med overvejelser over, hvordan optag af nye medlemmer skal foregå i fremtiden, da det er en krævende opgave. Klubben har mange henvendelser. For eksempel er der fem unge på introduktionsbesøg, mens jeg var der. Overvejelserne vedrører midlertidigt stop for indtag, så der kan arbejdes med den medlemsgruppe, der er stabil i klubben i øjeblikket, eller indtag i 'puljer' for eksempel månedligt, så nye medlemmer kan introduceres til Klubben i samlet trup for at spare medarbejderressourcer ${ }^{41}$. De unges oplevelse er, trods den belastning det kan være for medarbejderne, at "Man bliver taget rigtigt godt imod herinde, det er fordi, det er jo andre unge, der tager imod en. Det betyder meget " (Stig \& Halfdan, medlemmer Klub Fontana).

Fontana henvender sig til unge med psykisk sårbarhed spændende mellem unge, der har en diagnose som sindslidende til unge, som kun lige har oplevet en begyndende psykisk sårbarhed. Men som en af medarbejderne udtrykker det, så er det et faktum, at "Mange af vores unge er meget syge" (Else, medarbejder Klub Fontana). Denne grundlæggende opfattelse af medlemsgruppen må ses som baggrund for de måder at møde og være sammen med de unge, der er fremherskende i samspillet i Klubben og som noget, der har konsekvenser for, hvad der er betydningsfuldt i klublivet inde i Fontana, og hvem der tiltrækkes af hverdagen i Klubben.

I Fontana har hvert medlem en kontaktperson. Som udgangspunkt kan den enkelte selv vælge mellem medarbejderne, hvem han/hun ønsker som kontaktperson. Det er kontaktpersonen, der sørger for at holde 'fingeren på pulsen' med det enkelte medlems situation i form af både det daglige samvær (hvor den unge til enhver tid kan bede om en snak) og den mere formelle fastholdelse af kontakten med tremåneders MUS samtalerne, som er del af hele Fountain House Københavns arbejdsmetode. Kontaktpersonen hjælper også medlemmerne med kontakt ud af Fontana med samtaler med myndigheder, sagsbehandlere mv. Det behøver ikke være kontaktpersonen, der hjælper. Det

\footnotetext{
${ }^{41}$ I Bogstøtten i FH K ser de det som helt essentielt, at de kan sige til en, der henvender sig, at vedkommende kan starte med det samme, mens man i Kontoret og Køkkenet i FH K samler nye medlemmer ugentligt eller hver fjortende dag til samlede introduktionsforløb i Enhederne. I FH Å har man en optagelsesprocedure, hvor nye kan deltage i introduktionsmøder eller træffe enkelt-mands aftale om en 1-gangsbesøg og siden, efter 14 dages betænkningstid, komme til en reel opstartssamtale, hvor starten mv. aftales endeligt.
} 
afhænger af hvem af, medarbejderne den unge retter henvendelse til i den konkrete situation ${ }^{42}$.

$\rightarrow$ Freja $\left(\mathrm{M}^{43}\right)$ hiver fat i Felix (MA) og spørger, om han vil hjælpe hende med at ringe nu. Det vil han. De har åbenbart tidligere drøftet, hvad det handler om: Freja har fået nogle bøder for at glemme sit togkort, og hun har problemer med at betale hele beløbet på en gang. Felix ringer op til DSB. Efter et par omstillinger får han fat i den rigtige person og fortæller, at han hjælper en ung borger med at finde en løsning på et bødeproblem, og at hun nu får den unge selv i røret. "Det kan du godt", siger Felix til Freja, som tager røret og præsenterer sig og fortæller om sit betalingsproblem. De aftaler tydeligvis en afdragsordning, som passer Freja, og hun får information om, hvad hun nu skal foretage sig i sagen. Freja slutter samtalen og fortæller Felix, der spørger, hvordan det gik, 'hvordan og hvorledes'. Felix opfordrer Freja til at huske at betale afdragene og gemme kvitteringerne. Hun spørger, hvorfor hun skal gemme dem, for så har hun jo betalt, og han forklarer det for hende. Så spørger han, om hun synes det er overkommeligt nu, om hun kan klare det med den aftale, der er lavet. Det mener hun, det er, og hun siger, at hun allerede nu vil lægger penge til side, selv om hun først skal betale til næste første. "Det lyder fornuftigt" siger Felix. "Tak for hjælpen" siger Freja og taster betalingsdagen ind i sin kalender $\leftarrow$ (Feltsekvens Klub Fontana fredag den 26.marts 2010)

Klub Fontana har fem medarbejdere - to mænd og tre kvinder. De har arbejdet i Fontana mellem fire måneder og 15 år. Medarbejderne i Fontana er, ligesom i resten af Fountain House, en tværfaglig medarbejdergruppe. Som sådan er de en terapeutisk/akademisk uddannet leder, en ergoterapeut, en design/psykiatriuddannet, en socialrådgiver og en socialpædagog.

Men, som det pointeres for feltarbejderen, da jeg spørger til deres faglige baggrund, er det ikke deres socialfaglige uddannelses- eller erfaringsbaggrund, der tegner deres fælles faglighed alene; men deres fælles forståelse af opgaven, som afstedkommer den måde, de er enige om at møde medlemmerne. Dette kommer, efter medarbejderne egne udsagn til udtryk i en fælles 'groundedhed', som de definerer som en særlig Klub Fontana faglighed, der kan rumme den

\footnotetext{
42 "Jeg har lige haft en svær samtale i telefonen, men så havde jeg Ejvind ved siden af, og det er han rigtig god til. Når jeg kan det, med ham ved siden af, så kan I også ringe" (Emilie, medlem Klub Fontana) ${ }^{43}$ Medlemmer præsenteres første gang de nævnes i det enkelte feltuddrag med (M) efter deres navn (anonymiseret), medarbejdere præsenteres første gang de nævnes i det enkelte feltuddrag med (MA) efter deres navn (anonymiseret).
} 
enkelte unge og hans/hendes oplevelse af sin situation - uanset hvad. "Vi er så gode sammen, og vi hænger sammen" (Lis, medarbejder Klub Fontana).

Fysisk er Fontana placeret i den ene ende af Fountain House huset, og råder som sådan over fire etager med Cafe med cafekøkken øverst, undervisnings-/mødelokalet Kahytten og kontor i forskudt mellemetage i midten og sofarum i kælderen. Hertil kommer en terrasse, som breder sig i flere niveauer over gården rundt om springvandet (fontænen) og sammenbinder Klub Fontanas Cafe med det øvrige Fountain House på udendørs plan. Men for at komme ind i Fontana må man også gennem selve Fountain House. Først Receptionen, hvor der hilses godmorgen eller velkommen, og dernæst forbi Kontor og vaskehus hen til den 'rigtige' indgang til Klubben, hvortil der hører registrering med navn på en liste, som ligger fremme lige udenfor Fontanas lokaler.

De fire lokaliteter, der er Fontanas 'indre rum', er indrettet som Klublokaler med cafe-borde, stole, sofaer, planter, blade og pjecer, billeder og malerier på væggene fra malerprojekter, brætspil, computere, planlægningstavle, aktivitetsopslag med tilmeldingslister, staffelier og andet kreativitets-grej, opslag om omgangsformer ${ }^{44} \mathrm{mv}$.

Cafeen er, ligesom terrassen er det i godt vejr, også mødested med resten af Fountain House, idet de unge driver Cafeen som det sted, hvor alle medlemmer og medarbejdere hver dag køber deres kaffe og har mulighed for at sidde og holde pause. En gang om måneden inviterer Fontanas medlemmer alle, der har haft fødselsdag i Fountain House den forgangne måned på fejring med fødselsdagskaffe og hjemmebag i Kahytten.

Ud over driften af Cafeen køres forskellige aktiviteter, som de unge kan deltage i. Det er aktiviteter af kortere eller længere varighed, der enten foregår inde i Klubben - mens jeg var i feltstudier kørte "Sundhedsprojektet" (over 5-6 uger) med indhold omkring motion, kost og psykisk velvære, eller i andre lokaliteter i Fountain House væk fra selve klublokalerne - mens jeg var i feltstudier kørte "Uddannelses Klubben" (en projektaktivitet af et halvt års varighed).

Andre aktiviteter er knyttet til klublivet mere generelt. Dagligt tilbagevendende er de koordinerende enhedsmøder kl.10 og kl.13, som medarbejderne styrer. Her præsenteres dagens aktiviteter og arbejdsopgaver, og medlemmerne melder sig på ${ }^{45}$. Aktiviteterne er for eksempel mandegruppe,

${ }^{44}$ F.eks.: "Vi er alle forskellige og det skal vi blive ved med"

${ }^{45}$ De unge møder typisk fra kl. lidt i 10 og fremefter. De sidste dukker op et par timer før Klubben lukker kl.16 mandag til torsdag og kl.15 om fredagen. Fontanas medarbejdere møder kl. 8.30, deltager i det fælles Fountain House morgenmøde k1. 8.50 (åbent for medlemmer) og har koordineringsmøder og administrativt arbejde før dagens første enhedsmøde med medlemmerne. 
håndarbejde, fitness $\mathrm{i}$ et center i nærheden, gåtur i Fælledparken, morgenløbegruppe mv. Aktiviteter af den karakter foregår typisk over fem-seks uger, fordi det er den periode, medarbejderne har erfaring med, at de unge har lyst til at engagere sig i den samme aktivitet. Herefter skiftes aktiviteterne ud med andre aktiviteter.

De fleste aktiviteter har karakter af at være undervisningslignende i den forstand, at aktiviteten er indholdsbestemt af medarbejderen og ved at medarbejderen agerer lærer, der holder oplæg som optakt til aktiviteten, som styres af medarbejderen. På et møde definerer en af medarbejderne deres selvforståelse af Klub Fontana som en slags skole: "Vi opfatter os selv som en slags skole med processer i form af kurser" (Felix, medarbejder Klub Fontana).

To, lidt anderledes, 'aktiviteter' er så grundlæggende for medarbejdernes forståelse af, hvad Klub Fontana er og skal, at det modsat de øvrige aktiviteter i nær fremtid tænkes at skulle køre vedvarende og spredes fra at være del af Sundhedsprojektet til at gælde alle medlemmer. Det er Fremtidsværksted og Coaching. Som jeg har lært Klub Fontana at kende gennem feltstudierne, afspejler disse to aktiviteter det, medarbejderne ser som Klubbens kerneydelse i den forstand, at de med disse to aktiviteter er særligt fokuserende på den enkelte unges oplevelse og udvikling af/i sin situation Her og $\mathrm{Nu}$. I praksis er disse aktiviteter 'steder', hvor medlemmerne opfordres til at udtrykke sig i ord om deres situation.

Analyserne af feltmaterialet har givet anledning til en tredeling $\mathrm{i}$ formidlingshenseende: Det er henholdsvis Klub Fontana som unge-milø, Klub Fontana som pædagogisk setting og Klub Fontana som Fountain House tilbud for målgruppen unge med psykisk sårbarhed. Samlet set kan en særlig opmærksomhed rettes mod betydningen af aktiviteter fra de tre forskellige formidlingspositioner, det er at søge de unges perspektiv om, hvad der er særligt meningsfuldt i klublivet, et pædagogisk perspektiv på Klubben, og et perspektiv om Klubben som Fountain House tilbud.

\section{Klub Fontana som unge-miljø}

Mit første møde med Fontana var som et unge-miljø i Fountain House. På den indledende rundvisning i Fountain House præsenteres Fontana som "Det er her, de unge holder til og driver vores Cafe" (Gunner, medlem FH K). Som sådan er 'de unge' - fysisk med egne lokaler, såvel som i opfattelse adskilt fra 'de andre'; men de er accepteret som en særlig gruppe $i$ Fountain House. "De unge fra Fontana, det er jo dem, der søger for, at der altid er den nødvendige kaffe, så vi kan få vores pauser" forklarer Lotte (medlem FH K) en gruppe besøgende.

I min gang i huset, før mine feltstudier i Fontana startede, lagde jeg mærke til forskellene til Klubhusene, som jeg havde lært og var ved at lære dem at 
kende. For i Fontana slænger medlemmerne sig i sofaer, der er musik fra højtalerne, spil eller youtube/nettet på computerne og aktivitet med mobiltelefoner og Ipods. Fontana ligner noget 'andet' end arbejdsenhederne i Fountain House i almindelighed.

Men set som ungemiljø er Fontana, set fra den udefrakommendes position, også 'helt almindelig', med optagethed af hvor vennerne er, fnis og udråb, drenge og piger, mobiltelefoner og musik. Og når man træder ind i Fontana, kan det første indtryk siges at vedblive at være del af indtrykket. " $V i$ hænger ud", lyder svaret ganske naturligt, når en medarbejder spørger "Hvad laver I?", da hun gerne ser aktivitet i Cafeen frem for selvbetjening. De unge 'bliver hængende' sådan som unge, der hænger ud i grupper, gør. De sidder sammen i sofaerne og rundt omkring på stolene til sent om eftermiddagen, eller lidt over endt pausetid, passer deres sms-korrespondancer, ryger på terrassen, går i Føtex efter frokost fordi det passer dem bedre end dagens ret i Kantinen, spiser kage eller spiller spil. Det at hænge ud kan således siges at være 'indholdsbestemt' af de unge selv inden for Klubbens fysiske og sociale rammer.

De unge er unge som mange andre unge, der helst ikke vil svede til motion, har ondt i knæet måske fordi motionsformen ikke rigtigt appellerer, eller går 'hjem' før gå-tur-aktiviteten er slut, eller deltager tilbagelænet i madlavningsundervisningen: "Jeg skal i hvert fald ikke røre ved råt kød" lyder det, har svært ved at sige 'ja' til pige-nummer-tre, som gerne vil være med, godt vil noget "hvis der er en mere, der vil" etc. Det kan alt sammen ses som udtryk for, at de unge deltager på en karakteristisk ungdommelig måde. Og Fontana kan ses som et ungdoms-rum, hvor alt dette har plads, som det har i andre ungdomssammenhænge så som i ungdomsuddannelser, fritidsjobs og til diverse fritidsaktiviteter.

Det alment ungdommelige i miljøet understreges også af udtalelser fra medarbejderne som "Det er helt normalt, det gør alle"; "Sådan har alle unge det", som betoner, at der er tale om et unge-miljø, og at sådan skal det også være ${ }^{46}$. Men med bevidsthed om, at de her unge også har særlige vilkår, og har brug for at blive bekræftet $\mathrm{i}$ deres ungdommelighed med troværdige meldinger om, at deres følelser og adfærd har med deres alder, ikke med deres særlige psykiske sårbarhed, at gøre.

Forståelsen af Fontana som ungemiljø nuanceres altså ved nærmere bekendtskab. Inde i livet i Fontana lærer man, hvad det der 'mere end

${ }^{46}$ Under mit feltstudie i Fontæne Huset i Århus mødte jeg et par unge medlemmer, der talte med drømmende stemme om Fontana i København, hvor man kan være sammen med andre unge. "Jeg ville virkelig gerne have, at vi havde sådan et sted" (Folmer, medlem FH Å) "Det kunne vare dejligt med sådan et sted, som de har for unge. Jeg savner virkelig andre unge. Men det gode er, at vi bliver nok hurtigt modne her, når vi er så meget sammen med voksne" (Fiona, medlem FH Å) 
ungdommelighed', der på spil i samværet er, og via samvær med de unge forstår man mere om, hvad der er vigtigt; altså, hvilken funktion Klubben har i de unges liv, og hvad de forventer at være del af som medlemmer. Det skal uddybes i tre punkter.

For det første vil jeg pege på, at Fontana er et unge-miljø, hvor de unge er opmærksomme på, at de er der af særlige grunde - at de er netop der og ikke andre steder (i uddannelse/job), fordi de har særlige behov. "Herinde kan jeg få dagen til at gå $i$ nedsat tempo $i$ stedet for at ligge derhjemme" forklarer Vilhelm (medlem Klub Fontana) sin sagsbehandler om sit behov for et sted at komme, hvor kravene er anderledes end $i$ et almindeligt job eller i livet uden et fritidstilbud mellem 'flex-job-dage'.

Det samme giver Ella udtryk for, da hun forklarer nye medlemmer på introbesøg, hvad det er for en forskel, Fontana har gjort i hendes liv: Hun fortæller, ligesom Vilhelm ovenfor, at Fontana udgør forskelsmuligheden på at ligge hjemme på sofaen og så være kompetent del af noget socialt: "Jeg får rigtig meget ud af det-før lå jeg derhjemme, det gør jeg ikke mere ... I starten kunne jeg ikke rigtig sige noget uden at begynde at græde - Nu snakker jeg med dem alle sammen".

Medarbejderne understøtter de unges 'særlige' tilstedeværelse i Klubben med deres holdning. De siger for eksempel "Man har det, som man har det, og man er der, hvor man er. Man kan ikke være så mange andre steder" (Lis, medarbejder Klub Fontana) - eller som jeg taler med Ejvind (medarbejder Klub Fontana) om: "Vi gør de unge opmærksomme på det tidligt, faktisk allerede ved introsamtalerne, at der ikke er nogen, der forventer den der 'forstillede veloplagthed' af dem, som du lige kaldte det. De kan komme som dem, de er, og have det og være her som de nu har det".

Den holdning, som man kan sige vedrører medarbejdernes opfattelse af det tilbud Klubben skal være som ungemiljø, stemmer overens med deres grundlæggende opfattelse af ungegruppen som en gruppe, hvoraf 'mange er meget syge'. Og det ser ud til, at ungemiljøet som sådan befordrer de unges proces fra at ligger derhjemme, græde i mødet med andre mennesker mv., til at blive stabile deltagere i fællesskabet i Fontana.

Fællesskabet de unge bliver del af med deres medlemskab i Fontana, er det andet punkt angående Fontana som unge-miljø, jeg vil fremhæve. For Fontana kan siges at være et gensidigt omsorgsfuldt unge-miljø. "Jeg søger efter et sted, hvor der er andre unge at være sammen med, som har tomlet med nogle af de samme udfordringer, som jeg har - altså jeg har været syg siden jeg var 15 - Jeg vil gerne høre, hvordan de også har taklet det", siger en pige på førstegangsbesøg om sit behov for et sted at være del af noget socialt, der har den særlige karakter, der kendetegner Fontana.

Som gensidigt omsorgsfuldt unge-miljø er det også et miljø sensitivt for stemningsskift, der påvirker den gensidige tillid i unge-gruppen. Det kommer jeg tilbage til. 
Man kan sige, at den omsorgsfulde omgangsform starter ved 'indgangen' til klubben, eftersom de unge lægger stor vægt på den måde, de selv blev taget i mod og på modtagelse af nye. De unge føler sig taget godt imod, når de starter i Fontana. Et medlem forklarer et andet medlem om den oplevelse, han havde af sin introduktion i Klubben, som hun var med til "Jeg tvivlede på det, da jeg hørte det ['at man bare er med fra starten, og der er ikke nogen, der ikke er med', som Aila forklarer mig om AH], altså, at det kunne være rigtigt, men fordi du var medlem, fordi det var dig, der sagde det, så fik det mig til at lytte - og så startede jeg" (Vilhelm, medlem Klub Fontana). Aila uddyber: "Der er sådan en blød stemning, når man starter. Jeg har aldrig mærket det nogen andre steder, jeg har været. Så man kan slet ikke lade være med at åbne op og være åben overfor andre" (Aila, medlem Klub Fontana).

$\rightarrow$ Vi er på gå-tur i Fælledparken. En af de unge fortæller, at han mener at modtagelse af nye er meget vigtigt, men også en udfordring, fordi de fleste af de unge derved kommer i kontakt med det, de har svært ved nemlig 'det sociale': "Jeg ved ikke, om jeg er god til det, men jeg vil gerne være god til det, - god til at tage imod nye; jeg tror ikke de synes det altid. Der kommer også rigtig mange, - for det kan godt være svært at se folk i øjnene, og så føler de måske ikke, de er blevet taget så godt imod", siger Laus (M). Agnete (M), som lige har fortalt, at hun synes det er hårdt at være ny, med alle de nye mennesker man møder, svarer, at hun synes Laus har været god til det. Man kan tydeligt se, at han bliver glad "Syns' $d u$. Tak", siger han - Og de to tager initiativ til at spille spil sammen i flere pauser $\mathrm{i}$ de efterfølgende dage. Lis (MA) blinker til dem og siger "Nåå, Agnete banker du Laus $i$ UNO?" $\leftarrow$ (Feltsekvens Klub Fontana tirsdag den 20.april 2010)

Laus er tryg ved de andre medlemmer, han har været i Fontana et godt stykke tid. Derved har han overskud til at drage omsorg for Agnetes problemer med at 'falde til' blandt alle de nye mennesker, som hun făr fortalt om er svært for hende. For det har han for længst overstået. Omsorgen bliver til på baggrund af hendes markering til ham, om at hun har oplevet at han, trods sine sociale besværligheder, er god til at tage imod nye, som giver ham 'næring' til at fortsætte det gode arbejde. Den gensidige omsorgsfulde stemning er således fremmende for begge deres processer. Og dette understøttes af medarbejderens opbakning i situationen, hvor hun ved, at de begge arbejder med deres problematikker.

Den gensidigt omsorgsfulde omgangsform, der præger ungemiljøet, ses også, når de unge følger op på henvendelser fra hinanden "Jeg er ked af, jeg ikke kunne gå med dig før, fandt du en af følges med?" følger Karen (medlem Klub Fontana) op på en forespørgsel om at følges i Føtex. "Er du træt $i$ dag Molly, du 
ser lidt træt $u d$ ?" (Billy, medlem Klub Fontana), lyder det, og det giver åbenbart anledning til overvejelse, for lidt efter er trætheden vist alligevel ikke så stor, for Molly vælger at melde sig til en passe-Cafe-tjans i frokostpausen. "Vi kan tage 'humørbarometeret', så ved vi ligesom, hvor vi er ${ }^{47 \prime \prime}$, foreslår Ida (medlem Klub Fontana) i optakten til en aktivitet.

Den omsorgsfulde omgangsform, der er kendetegnende for de unges indbyrdes samspil med hinanden i Klub Fontana, er også hårfin og kan som sådan være under pres. Det ses, når noget ryster den tillid, de har til hinanden. I feltsekvensen herunder ses både den omsorgsfuldhed, de har for hinanden, og hvordan de på baggrund af deres værdsættelse af den tillid, det indebærer, bliver nødt til at værne om den, ved at reagere på en måde, der gør, at de kan få støtte af medarbejderne til at genoprette stemningen og omgangsformen:

$\rightarrow$ Mandag morgen er alle de unge helt tavse og ser triste ud. En af de unge har fået stjålet nogle penge om fredagen, da hun et øjeblik efterlod sin taske uden opsyn i Cafeen. På enhedsmødet kl. 10 giver flere unge udtryk for, at de er kede af, at de ikke føler, de kan stole på hinanden længere. Medarbejderne prøver løbende gennem formiddagen at forklare, at der ikke er nogen, der beskylder de unge, for det kan lige såvel være en fremmed, der er kommet ind fra gaden. De unge er fortsat stille, ser mutte og triste ud og der er ingen, der snakker sammen. Sidst på formiddagen bliver en af de unge meget vred over, at de ikke bliver taget alvorligt nok i deres fornemmelse af begyndende mistillid til hinanden: Han skælder ud og fremfører sit synspunkt mange gange i træk i højt, klart og insisterende toneleje. Medarbejderne, der først prøver at dæmpe ham, forklarer rationelt, at der ikke er nogen, der beskylder dem, der var i nærheden, for dem kan det af gode grunde ikke være, lytter 'alligevel' til hans budskab da han bliver ved med at fremføre det, og spørger de andre unge der sidder stille rundt omkring i Cafeen, om de kan genkende det, den unge udtrykker, han føler. Det kan de lige præcis, og det giver anledning til medarbejdernes initiativ til en fælles drøftelse på enhedsmødet kl.13 om, hvad der kan forandre stemningen igen: "Sådan at vi kan få det godt igen. Jeg synes ikke, der skal komme nogen udefra og ødelægge det, der er så særligt for Fontana - og hvis det endelig skulle være én her inde fra, så skal vedkommende bare se at komme og sige det til en medarbejder og få hjælp til at lægge den kedelige vane fra sig, det er, at være tyveknægt" (Else og Viola MA). Den unge, der blev vred, som er anledning til at 'sagen' tages op på enhedsmødet, forklarer, at "Jeg vil godt lige sige, at når jeg blev så vred før oppe i Cafeen, så

${ }^{47}$ Et humørbarometer er en runde, hvor hver enkelt ung siger, hvordan han/hun har det på en skala fra et til 10. 'Et' er helt nede i kulkælderen, hvor man egentligt helst ville være blevet hjemme, mens ' 10 'er 'helt oppe at ringe', hvor man har det rigtig godt. 


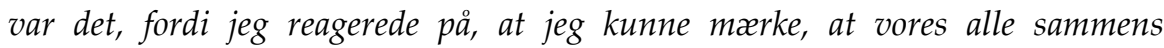
stemning var præget af det. Jeg vil godt sige, at det var derfor, jeg blev så vred" $\leftarrow$ (Feltsekvens Klub Fontana mandag den 19.april 2010)

For det tredje er aktiviteter særligt væsentligt at være opmærksom på i Fontana set som ungemiljø, fordi for de her unge ser det at hænge ud slet ikke ud til at være en ukompliceret ungdommelig omgangsform.

Fra feltarbejderens perspektiv er livet i Klub Fontana på samme tid et meget snaksomt-kommunikerende miljø (det afspejles i alle citaterne, som næsten alene tegner feltberetningen) og et ret tavst miljø. Jeg oplevede ugen igennem, at de unge sad side om side, flere sammen i grupper og var helt stille - både i klublokalerne, til møderne og til aktiviteterne. Jeg måtte finde ud af, hvad tavsheden udtrykte.

Først tog jeg medarbejderne 'på ordet' og opfattede det som udslag af, at de havde det rigtigt skidt (er meget syge). Men via analyserne fandt jeg ud af, at noget andet også kan ligge til grund ved de unges markering af betydningen af aktiviteter; nemlig en oplevet ubekvemhed som man kan forstå tavsheden, der er udtalt i de unges hængen ud, med.

Som medlemmet Laus forklarer, "Hvis man har det svart med social kontakt, så kan det godt være et pres, hvis man skal sidde her $i$ sofaen og finde på noget at sige. Så det eneste man er fxlles om er at sidde og være sammen om at kigge ned $i$ kaffekopperne". Agnete fortæller, at "Jeg kommer mest, når der er aktiviteter. Og her er også nogle aktiviteter, jeg godt kan lide. Det gør det også nemmere, at så har man noget at snakke om". Og Asbjørn, et gammelt medlem af Fontana, der vælger at vende tilbage, selv om han er gået i gang med en ungdomsuddannelse, forklarer i sin tilbagevendelses-drøftelse med en medarbejder: "Det er fordi jeg tror godt, jeg kunne tænke mig at være med til nogle aktiviteter, sådan som det er herinde $n u$, hoor man laver noget andet end at hænge ud".

At hænge ud kan altså ikke siges at være en ukompliceret foretrukken aktivitet set med perspektiv på Klub Fontana som unge-miljø for unge med psykisk sårbarhed, selv om det, som vist ovenfor, er en del af medlemmernes ungdomsliv i Fontana. Man kan sige, at det for unge med psykisk sårbarhed inde på livet kan være forbundet med ubekvemhed spontant at bidrage til og deltage i det sociale liv i Klubben.

At hænge ud forekommer i forskellige sammenhænge. Nogle gange 'selvvalgt' (for eksempel når en gruppe unge afbryder en gåtur-aktivitet, før den er færdig, eller efter en aktivitet fungerer det som 'hvile-/opladningspause', eller når en frokostpause strækkes lidt over kl.13). Men det ser også ud til, at der bliver hængt ud i mindre selvvalgt form, når der ikke er energi nok, eller der måske mangler oplevelse af meningsfuldhed i den udbudte aktivitet til at reagere på en opfordring fra medarbejderne om netop ikke at hænge ud. For 
eksempel når der er praktiske opgaver, der trænger til at blive løst i Cafeen: "Vi skal have fyldt op, vi har købt en masse ind - og der er også kopper til opvask ... [ingen rejser sig fra sofaen, hvorfra de unge har fortalt, at 'Vi hænger ud', da medarbejderen spurgte, 'Hvad laver I?' AH] ... I kan nok høre, jeg spørger jer om noget hjælp; jeg prover at sætte jer i gang"' (Lis, medarbejder Klub Fontana).

Eller når en aktivitet simpelthen bliver valgt fra, så er der 'ikke andet at gøre' end at hænge ud. For eksempel hvis en aktivitet stopper, før det var tiltænkt, fordi de unge selv siger nej til at deltage i den 'på aktivitetens præmisser'. Det skete den første dag jeg var på feltstudier i Fontana, hvor ingen af de unge havde noget, de ville bringe op i Coaching. Så er der tilsyneladende ikke andet at gøre end at hænge ud.

Hertil er det en væsentlig pointe, at det er helt grundlæggende for de unge i Fontana, at de har svært ved at være 'igangsættere'. Som Vilhelm (medlem Klub Fontana) siger til sin sagsbehandler: "Jeg er ikke så god til at få sat tingene $i$ gang; men fär jeg en udfordring, så skal jeg nok løse den. Jeg kan godt lide at få et problem at arbejde med, men jeg kan ikke så godt få sat det $i$ gang selv". Medarbejderen Ejvind svarer: "Det Vilhelm siger der, er generelt for alle vores unge her" ${ }^{\prime \prime 8}$.

At hænge ud er altså det man kan, hvis/når man ikke kan andet eller der ikke er andet at gøre - af den ene eller den anden grund og mere eller mindre selvvalgt. Det kan altså være manglede oplevelse af meningsfuldhed i de aktiviteter, der foregår såvel som på grund af problemer med at tage initiativ. Under alle omstændigheder sidder de unge tilbage med ubekvemheden om 'at det sociale, uden noget at lave sammen eller ved siden af hinanden, er svært', fordi det sætter dem i direkte kontakt med deres sociale problematikker: "Det, at der er aktiviteter, det gør, at man fär noget struktur på sin hverdag. Der er noget at stå op til. Og så er der noget, man kan snakke om, som man har sammen herinde. Så behøver man ikke blande noget privat ind $i$ det, for det er jo ikke sikkert, at man har lyst til det" (Laus \& Miranda, medlemmer Klub Fontana).

Aktiviteter, som væsentlig del af Fontanas organisation, tages op igen under de to følgende vinkler om Fontana som henholdsvis pædagogisk setting og som Fountain House for unge med psykisk sårbarhed.

48 Under mit feltstudie i Kontoret mødte jeg et medlem fra Bogstøtten, som gjorde mig opmærksom på, at han overvejer (og prøver Kontoret af i den sammenhæng), i hvilken retning han skal 'omskoles' fra murer, for det at lave monotomt arbejde, uden udfordringer at tage stilling til, gør ham alt for alene med sine egne tankerækker. Vilhelm fra Fontana siger præcist til sagsbehandleren, at han ikke ønsker at arbejde som elektriker på en byggeplads igen, fordi han ikke bliver udfordret i sine tanker, hvis han skal gå og trække ledninger og trække ledninger og trække ledninger. 


\section{Klub Fontana som pædagogisk setting}

Lige såvel som jeg fulgte Fontana som de unges klub, mens jeg var på feltstudier, fulgte jeg også Fontana som pædagogisk setting. Som udgangspunkt var det en drøftelse på medarbejdernes koordineringsmøde på min første feltstudiedag, der satte mig på sporet af Fontana som pædagogisk setting, for her mødte jeg medarbejderne som pædagogiske medarbejdere.

Når det ikke nødvendigvis er en selvfølge, at medarbejderne fremstår tydeligt som pædagogiske medarbejdere, er det, fordi Klub Fontana er del af Fountain House, som i hvert fald i sin 'reneste form' er kendetegnet ved ligeværd i deltagelse i hverdagslivet uden fora, hvor medlemmerne som gruppe eller som enkeltpersoner, eller tilgangen til dem, er 'til drøftelse' hos medarbejderne.

På det omtalte mandagskoordineringsmøde drøftede medarbejderne, at de for tiden oplever at have med en ungegruppe at gøre, som ikke tager ansvar $\mathrm{i} /$ for fællesskabet. Medarbejderne oplever, at det er kendetegnende for ungegruppen, at de har brug for at blive 'uddannet' heri. Derfor besluttede medarbejderne, at de vil afkræve den enkelte unge stillingtagen til, hvad vedkommende byder ind og bidrager med. "Vi skal hive fat $i \mathrm{dem}$ ", konkluderer Else (medarbejder Klub Fontana).

I ugen der følger, uanset hvilken medarbejder der styrer dagens to enhedsmøder, spørges hver enkelt ung, som ikke selv melder til, hvad vedkommende vil og hvad han/hun gør. Og hvis der er nogen, der ikke er til stede på mødet: "Hvor blev de af, de var her da til frokost? - Nå, de to fär også at vide, at de skal hjælpe til på det hold, så snart vi ser dem" (Lis, medarbejder Klub Fontana).

Jeg har tidligere nævnt, at medarbejdergruppen er en tværfaglig gruppe. $\mathrm{Og}$ at de ikke ser deres socialfaglige uddannelses- eller erfaringsbaggrund som det, der tegner deres faglighed alene; men at det er deres enighed i form af en 'groundedhed' i deres måde at møde de unge. "Hvis vi bare er groundede sammen, så kan vi også alt det andet, vi står overfor", siger Felix (medarbejder Klub Fontana), da medarbejderne planlægger, hvad der skal være deres fokus på deres kommende medarbejderdag.

Medarbejdernes groundedhed kommer, under deres egen synsvinkel til udtryk ved, at de repræsenterer en unik Klub Fontana tilgang til unge med psykisk sårbarhed. En tilgang, der kan rumme de unge og de unges oplevelse af deres situation - uanset hvad. "Vi har en stor sikkerhed på hinanden, en tiltro til, at vi løser tingene på en måde, der er indenfor vores fælles tankegang og hoad der er Klubbens særkende" (Ejvind, medarbejder Klub Fontana).

Jeg blev selvfølgelig nysgerrig overfor, hvad den faglighed består i. Et af elementerne er ifølge medarbejderne selv deres arbejdsmetode i kontakten med de unge, hvor de benytter bestemte samtaleredskaber. "Alle medarbejdere $i$ 
Fountain House skal kunne tage 'den gode samtale'" (Gudrun, ledelsesperson FH $\mathrm{K})$.

I Fontana er det $\mathrm{i}$ form af metoden Proces Inquiry (i daglige tale P.I.). P.I. har 'Her og Nu' som hovedfokus. Derfor er det ikke en behandlingsform eller terapi, understreger medarbejderne. Det er indbygget i P.I., at "Det er de unges proces. Det skal de komme og tage ansvar for, men vi er her som medarbejdere, som en enig og samlet trup, der gerne vil facilitere og hjxlpe og stotte med at de udvikler sig $i$ processerne; men processerne er de unges" (Ejvind, medarbejder Klub Fontana). Udtalelser som "Det jeg tænker, er ..." og "Jeg tænker ... kan du bruge det til noget?" lyder endog meget ofte i Fontana i medarbejdernes kommunikation med de unge, - hvad enten det er i almindelig samtale, aktivitetssammenhæng, eller under mere formaliserede samtaler (MUS, 'intro').

Man kan sige, at sådan nogle talemåder indikerer overfor de unge, at de suverænt er herre (eller skal blive det) i 'eget hus' - Det er ikke medarbejderen, der står for den endelige fortolkning af eller løsning på et problem. Men medarbejderen stiller sig alligevel til rådighed som en slags rådgiver, eftersom medarbejderen ikke lader det være fuldstændig op til den unge at finde svarene 'inde i sig selv'. Med "Det jeg tænker er...", giver medarbejderen sit besyv eller et kvalificeret bud med på vejen. For som Else (medarbejder Klub Fontana) siger, er det et vilkår, at mange unge i Fontana er meget syge, og det betyder, at "Det er præcist noget af det vi er så vanvittigt gode til i Fontana, at vi kan se, hvor den unge er og stille de krav, der er relevante lige i dag. Det kan sagtens vxre helt anderledes, end det var i går. Det vi kan, er altså, at vi kan rumme den unge, uanset hoordan det nu er, han eller hun har det". Hun fortæller, at de kan møde de unge 'fra minut til minut', om de så har det godt eller skidt.

Der er altså fokus på den enkelte unges befindende, og hvordan den enkelte unge via Fontana kan hjælpes/støttes i den situation, han/hun nu er i. Men som pædagogisk setting er der, som jeg præsenterede ovenfor, også fokus på fællesskabet. For det er i fællesskabet, at processerne tænkes at foregå. Det høres blandt andet på medarbejderne på det omtalte koordineringsmøde om problemet om 'fælles ansvar: "[det er vigtigt at] de får noget uddannelse $i$, hvad et Klubhus er med hensyn til fxlles ansvar" (Lis, medarbejder Klub Fontana). Og det ses i deres opfølgning i samværet med de unge på enhedsmøder og ved aktiviteter.

$\rightarrow$ Formiddagens aktivitet er 'kraft træning', en motionsform der består i en blanding mellem kampsport, yoga, dramatisering, afspænding mv. Det er en undervisningspræget aktivitet forstået på den måde, at den er ledet af en af medarbejderne med et oplæg fra medarbejderen om psykisk befindende før selve motionen starter. Da det foregår i klublokalet Kahytten, skal stole og borde fjernes, før vi kan komme i gang (der har lige 
været enhedsmøde, hvor alle har siddet rundt om et stort bord). Men der skal også gøres rent, eftersom vi skal lave nogle af øvelserne liggende på gulvet. "Vi skal faktisk have gjort rent inden vi kan gå $i$ gang med træningen. Det hjelpes vi lige ad med - Jeg har gjort det de andre gange, men det er ikke fair, synes jeg. Så $i$ dag hjelper vi hinanden" siger Else (MA). Vi hjælpes ad med at flytte borde og stole mens dem, der ikke skal være med til aktiviteten efterhånden går op i Cafeen til de opgaver, de har meldt sig til. Ida (M) henter en kost og begynder at feje. Else henter vand i en gulvspand og en moppe. Da vi er færdige med at feje, spørger hun Molly (M), om hun er klar på at svinge moppen i en gang gulvvask. Det er Molly. De andre unge går ovenpå. Medarbejderen går ud og snakke med en ung og en kollega. Da gulvet er tørt hentes alle ned med et "Så går vi $i$ gang" fra Else $\leftarrow$ (Feltsekvens Klub Fontana torsdag den 22.april 2010)

I medarbejdernes professionelle møde med den unge som medlem, bliver der altså sat gang i oplevelsen af, at medlemmet har mulighed for at bidrage til fællesskabet, ved at de opgaver, der lige nu er gode for fællesskabet gøres synlige som 'noget vi kan være fælles om'/noget der kan ydes et bidrag til. Det gør sandsynligvis opgaverne meningsfulde og meget konkrete for de unge medlemmer - altså, at det er med henblik på motionsaktiviteten, der skal gøres rent, modsat en kedelig rengørings-tjans i sig selv. Og der støttes individuelt til den enkeltes deltagelsesmulighed, ved at medarbejderen gør vaskevandet klar og tilbyder det til én, hun måske ved gerne vil deltage/bidrage, men som har svært ved at tage initiativet og selv overskue, hvad der skal til for at blive deltager og bidrage. Mens medlemmet som selv 'tager fra' får plads til at udføre sin del af opgaven (med fejningen).

Fontana præsenteres som et sted, hvor sådan nogle måder at være sammen på er dagligdag. Og dermed som et sted hvor man som ung med psykisk sårbarhed skal ville og kunne magte det (med støtte): "Det er ikke sådan her, at så laver medarbejderne en masse ting klar rent praktisk, og så skal I unge bare komme og lave det sjove. Nej, vi laver tingene sammen her", fortæller Else (medarbejder Klub Fontana) nye medlemmer på introbesøg.

I foregående afsnit om Fontana som ungemiljø, fortalte jeg om, hvordan de unge ser aktiviteter som en væsentlig del af grunden til at vælge at komme og vedblive at komme i Fontana. Det ser ud til at konkrete aktiviteter, hvor det er tydeligt, hvad man kan bidrage med, og hvad man er sammen om, med hensyn taget til 'initiativproblemet', appellerer til de unge. Særligt som meningsfuldt modstykke til ubekvem hængen ud. "Jeg synes, det var godt at lave noget konstruktivt, noget hoor man skal koncentrere sig og bruge hovedet" siger Laus (medlem Klub Fontana) i evalueringen af fredagens maleaktivitet. De unge roser altså Klubben for at have aktiviteter og siger, at de især kommer, når der 
er oplevet meningsfulde aktiviteter eller opgaver at deltage i. "Det er det jeg glæder mig allermest til ved torsdagene her, det er, når jeg skal være med til at afholde intromøde" siger Karen (medlem Klub Fontana), da en medarbejder spørger, om hun har mulighed for at komme og deltage i mødet.

Men det er alligevel to lidt anderledes aktiviteter, der grundlæggende indrammer Fontana som pædagogisk setting, hvis synsvinklen er på medarbejdernes perspektiv - Altså, på hvordan medarbejderne udtrykker, at de gerne vil indgå i støttende samspil med de unge. Det vil sige, som særligt fokuserer på at støtte den unges oplevelse og udvikling af sin situation her og nu.

Det er aktiviteterne Coaching (hvor hver enkelt ung på skift tager et påtrængende problem op, som vedkommende gerne vil have hjælp til via 'P.I. samtale' med den medarbejder, der leder coachingaktviteten) og Fremtidsværksted (hvor den unge, ledet af en medarbejder, der bruger P.I. samtaleredskaber overfor den unge, arbejder fremadrettet med sine vanskeligheder og muligheder).

De to aktivitetstyper tænkes af medarbejderne at være så grundlæggende $\mathrm{i}$ Klub Fontana, at de planlægges at skulle køre vedvarende og spredes fra at være del af Sundhedsprojektet til at gælde alle medlemmer.

De unge ser også ud til at være optaget af det, der rører sig i deres liv her og nu, og på mulighed for at få hjælp til det fra medarbejderne. Som Ella (medlem Klub Fontana) udtrykker det forklarende for nye medlemmer: "Hvis jeg havde en dårlig dag, så snakkede jeg med Ejvind, og så kunne jeg pludselig godt holde ud at vare her".

Men analysen af feltmaterialet viser, at det kan fortolkes sådan, at medlemmerne godt vil holde det svære 'ude af fællesskabet' frem for drage det ind i fællesskabet. Altså, som noget de har mulighed for at drøfte med medarbejderne sideløbende med 'klublivets ønskede aktivitetsbaserede fællesskab'. For det kan tolkes sådan, at de unge henviser til aktiviteter af 'konkret karakter', mere end aktiviteter som spørger til deres psykiske befindende, som særligt meningsfulde i deres ungeliv i Klubben, eftersom det er 'noget at lave sammen', 'noget at snakke om' der er i fokus i deres markeringer, mere end aktiviteter der inddrager deres psykiske befindende.

Det, der kan siges at stå i modsætning til denne fortolkning, er, at to unge uafhængigt af hinanden i hver sin ende af min uge i felten spørger til, om gruppen (i henholdsvis enhedsmøde og motionsaktivitet) ikke lige skal lave et 'humørbarometer', for "Så ved vi ligesom, hvor vi er" (Ella \& Ida, medlemmer Klub Fontana). Men dette kan også netop tolkes ind i den gensidigt omsorgsfulde omgangsform, der præger Fontana, fremanalyseret ovenfor, om at de gerne vil vide, hvordan de andre har det, så de kan 'gå relevant' til hinanden den pågældende dag. 
Jeg vil tro, at dette kan afføde dilemmaer i Klub Fontana set som pædagogisk setting. For forskellen på de aktiviteter, jeg mener, de unge fremhæver og dem medarbejderne ønsker udbredt, er deres forskellige fokus. Det er med medlemmerne Laus og Mirandas ord: "[Med aktiviteter,] så er der noget, man kan snakke om, som man har sammen herinde. Så behøver man ikke blande noget privat ind $i$ det, for det er jo ikke sikkert at man har lyst til det". Hvorimod medarbejderne lægger vægt på at bringe de individuelle processer ind i fællesskabet med medarbejderen som facilitator: "Coaching er, at så sidder de der alle sammen, men det er kun den, der bliver coachet, der må sige noget. Selvfølgelig må de andre godt sige noget til sidst - 'det du sagde rørte også mig', for eksempel; men det er den unge, der bliver coachet, der selv skal finde svarerne via den samtale, vi har" (Else, medarbejder Klub Fontana). Jeg spørger til den oplevede effekt: "Den individuelle coaching $i$ gruppen gør det synligt for dem, at der er flere, der har det elendigt og har besværligheder" svarer Else.

Fokus ønskes altså lagt på 'pædagogisk udvalgte aktiviteter' med særligt henblik på at skabe rum for, at de unge kan arbejde konkret med deres individuelle problemer i frllesskabets vidende frem for i én-til-én-relationer mellem medlem og kontaktmedarbejder, som ifølge medarbejderne ellers har været fremherskende i Klubben.

Når jeg fremfører, at det kan give anledning til dilemmaer at bringe aktiviteter i fokus, som har den unges befindende i centrum frem for samvær og fællesskab om 'noget andet' via de mere klassiske klubaktiviteter, er det fordi analysen af feltmaterialet viser nogle forbehold fra de unge til deltagelse i disse aktiviteter. Det vil konkret sige, at de unge undlader at møde til den pågældende aktivitet fordi "Jeg sov" (Katinka, medlem Klub Fontana), og således slås medarbejdernes ide om proceskontinuitet $\mathrm{i}$ aktivitetsforløbet $\mathrm{i}$ stykker, eller de unge kan sige nej i selve situationen: "Nææ, jeg har ikke noget, jeg vil snakke om"(Freja, medlem Klub Fontana), hvorefter coachingaktiviteten må afbrydes, fordi det gør sig gældende 'bordet rundt'. Ligeledes kan de unge 'modificere' aktiviteten ved med deres deltagelse at bringe 'ufarlige' emner op så som "Jeg vil godt gøre rent på badeværelset til næste tirsdag" (Ida, medlem Klub Fontana) - som bud på et mål, der kan gøre noget godt i den unges liv inden for temaerne 'psykisk velbefindende, fysisk sundhed, sund kost, socialt liv', som den unge vil handle på i ugens løb og evaluere i fællesskabet til Fremtidsværkstedet i næste uge. Eller de unge kan sige bestemt fra: "Nej, det [at beslutte hvordan den unge kan arbejde med sine veninderelationer $\mathrm{AH}$ ] er ikke noget jeg vil have hjælp til. Det er noget jeg selv skal gøre. Jeg kan mærke, det er noget, jeg skal gøre med mig selv" (Miranda, medlem Klub Fontana).

Indtrykket er, at de unge præcist gerne vil være i klubben med hinanden og medarbejderne. Det giver dem hverdagsstrukturering, at så ved de, hvad de skal og det giver mulighed for at snakke med 'en voksen' om det, der rører sig i 
deres liv. Men det er også indtrykket, at de ikke er helt begejstrede for indholdet, uanset at medarbejderne tydeligvis vil dem det bedste dermed. Som Felix og Else siger, "Der er strukturer, men de bliver hele tiden udfordret af de unge; men de unge kommer hele tiden igen, så de vil gerne vare her - hvis det ikke bliver for 'loose'"' (Felix \& Else, medarbejdere Klub Fontana).

Det interessante, under en vinkel om Fontana som pædagogisk setting, er det spændingsforhold, som medarbejderne gør opmærksom på mellem på den ene side medarbejdernes oplevelse af at strukturerne bliver udfordret af de unge ("Det er jo frustrerende, at de ikke kommer. Det vanskeliggør jo den proces, der ligger indbygget $i$ de her aktivitetstyper som Coaching, Krafttræning og Fremtidsværksted er "(Else, medarbejder Klub Fontana) ${ }^{49}$ ) og på den anden side medarbejderoplevelsen om, at de unge gerne vil være i Klubben, hvis det ikke bliver for løst (som stemmer overens med analysen af de unges oplevede ubekvemhed ved manglende aktiviteter og initiativproblemer).

Spørgsmålet er, om man søger at få de unge til at tage ansvar i fællesskabet (og udvikle sig af fællesskabet) via en sammenholdsfølelse baseret på 'genkendelige psykiske besværligheder', frem for gennem det meningsfulde samvær omkring den type aktiviteter, de unge selv ser ud til at vægte? Lad det være optakt til se på Klub Fontana som Fountain House tilbud til unge med psykisk sårbarhed.

\section{Klub Fontana - Fountain House og unge med psykisk sårbarhed}

Klub Fontana er, som nævnt i præsentationen ovenfor, et Fontæne Klubhus tilbud til unge med psykisk sårbarhed. Derfor står Fontana også i forhold til Fountain House København og til Klubhusmodellen som ide for tilbud til mennesker med sindslidelse. Derfor er det relevant at inddrage praksis i Fontæne Klubhusene som en slags 'analytisk baggrund' for at kigge på, hvad der (også) er i spil i Klub Fontana.

I introduktionen til feltberetningen om Fontana, inddrog jeg min oplevelse af, at Fontana ved første øjekast skiller sig ud som anderledes end resten af Fountain House. Det er både fordi de unge opfører sig anderledes end Fountain House medlemmer almindeligvis gør (de sms'er, hører musik, hænger ud i sofaer, spiller spil mv.), og fordi de bliver opfattet som 'en særlig gruppe'

\footnotetext{
${ }^{49}$ De unges 'nej' (på den ene eller den anden måde) kan tolkes som modstand - altså som en 'praksisgengivelse' af medarbejdernes markering af, at 'strukturerne hele tiden bliver udfordret'. Men det kan også ses som udtryk for, at de unge præcist gør, hvad de har lært/øver sig $\mathrm{i}$ om at sige fra (overfor noget der ikke modsvarer deres oplevelse af, hvad der er sundt for dem og befordrende for udvikling i deres fællesskab) - og dermed et 'ja' til det, der befordrer deres fællesskab (udtrykt ved medarbejdernes oplevelse af at 'de unge kommer tilbage hvis det ikke er for loose').
} 
med egne lokaliteter, hvor de holder til - De er unge med 'deres eget domæne', og de ser ud til at beskæftige sig med andre ting i 'arbejdstiden' end de øvrige Fountain House medlemmer (de laver klubaktiviteter (så som håndarbejde, mandegruppe, motion og maleri), hænger ud og passer Cafeen (arbejder når 'de andre' holder fri)).

Nedenfor kommer jeg tilbage til, hvordan Fontana nærmere 'skiller sig ud' som Fountain House tilbud, når man opholder sig inde i livet der; men først noget om, hvordan Klub Fontana ligner et Fontæne Klubhus.

Der er flere måder, hvorpå Fontana kan genkendes som Klubhus. Som udefra kommende kan man for det første pege på, at 'de andre medlemmer' oplever, at Fontanas medlemmer understøtter den arbejdsorganisering, der er omdrejningspunktet i Fountain House: "De unge fra Fontana, det er jo dem, der sørger for, at der altid er den nødvendige kaffe, så vi kan få vores pauser" (Lotte, medlem FH).

De unge i Fontana er også del af Fountain House fællesskabet i den forstand, at de kan benytte mulighederne der i øvrigt ligger i huset. En ny pige fortæller, at hun kan blive rastløs og bange, hvis hun ikke ved, hvad hun skal lave. Medarbejderen fortæller, at de altid er glade for hjælp i Køkkenet. Om fredagen, ved mit forbesøg i Fontana, er der bud efter hjælp til Køkkenet. En medarbejder siger "Jeg vil godt gå derover, men jeg vil have en med". Der er straks en ung, der siger, at det vil hun gerne.

I samspillet med det øvrige Fountain House rammer man således Fontæne Klubhus formen ved, at medarbejdere og medlemmer deltager på lige fod i de opgaver, der er, og nye introduceres til formen om muligheder og nyttighed ved et bidrag, når lejlighed byder sig.

Det er også i markeringen af, at Fontana er for nogen der magter fællesskabet og magter at indgå i fællesskabets omgangstone, at Fontana ligner et Klubhus: "Man kan ikke isolere sig $i$ et hjørne og flygte fra, at 'nogen vil afkræve mig noget' her" (Felix, medarbejder Klub Fontana) forklares det til feltarbejderen, og det understreges af drøftelsen af ungegruppens behov på koordineringsmødet: "Vi skal ikke tilbage til kaffe-stue-hængen ... Jeg synes, vi skal spørge dem, der ikke byder ind, hoad de byder ind og bidrager med" (Else, medarbejder Klub Fontana).

Holdningen er, at man er fælles om tingene. Det introduceres til nye medlemmer: "Det er ikke sådan her, at så laver medarbejderne en masse ting klar rent praktisk, og så skal I unge bare komme om lave det sjove. Nej, vi laver tingene sammen her "(Else, medarbejder Klub Fontana ), og at alle med deres deltagelse varetager kontinuiteten. Daglige enhedsmøder går således igen i Fontana ligesom det gør i Klubhusene generelt. I Fontana er enhedsmøderne dog ledet af medarbejderne. 
$\rightarrow$ Det er kaffepause efter frokost i Cafeen. Vi (en medarbejder, fire unge og antropologen) sidder og hyggesnakker i sofaen og beundrer nogle hjemmedesignede smykker som et af medlemmerne, der lige er dukket op, viser frem. Men klokken er 13 og en af medarbejderne kommer ind og siger "Der er enhedsmøde" og går nedenunder igen. Lis (MA) rejser sig og siger "Går I med ned?". Sabine (M) opfatter det som et reelt spørgsmål og siger "Nej, jeg bliver her". Karen (M) siger "Jeg bliver også". Der er stille et øjeblik, så siger Lis "Det er bedst, hvis I alligevel går med ned, for det er det rigtige signal at sende". Vi går alle ned til enhedsmødet $\leftarrow$ (Feltsekvens Klub Fontana tirsdag den 20.april 2010)

Man kan sige, at der søges en struktur i organiseringen på linje med, at det er en af Klubhusmodellens pointer for rehabilitering at indgå i et forud struktureret dagsprogram. Det er også med fastholdelse af fælles redskaber som Medlems Udviklings Samtalen: "Jeg prøver at afdxkke, hoor den unge er henne med sin situation, og hvilke kontakter den unge har på plads, og så snakker vi om, hvordan den unge vil bruge Klubben og måske om forhåbninger" (Lis, medarbejder Klub Fontana), og med et generelt fokus på her og nu situationen i huset og hos medlemmerne: "Vi gider ikke snakke om i går vel? " - "Nej, vi er jo i Nu'et - Her og $N u^{\prime \prime}$ (Felix \& Ejvind, medarbejdere Klub Fontana), som den metodiske tilgang om Proces Inquiry understøtter. Det forud strukturerede Dagsprogram understøtter fokus på det, der dukker op her og nu, som medlemmet kan arbejde med i de aktiviteter og det fællesskab, han/hun er del af i Klubben.

I her-og-nu'et søger medarbejderen at rumme den unges oplevelse af sin situation. Medarbejderen kan lytte og spørge med P.I. redskaberne og give plads for processerne, som er den unges. De spørger, "Er der så nogen, du skal snakke med $i$ dag", når en ung har 'luftet' en problematik, og udbyttet af muligheden er tydelig for den unge "Hvis jeg havde en dårlig dag, så snakkede jeg med Ejvind, og så kunne jeg pludselig godt holde ud at være her" (Ella, medlem Klub Fontana).

Her og nu udtrykker en Fountain House ligeværdighed, hvor medlemmet 'skal være/blive herre i eget hus', med den støtte der skal til, for at det efterhånden kan lykkes. Men det er også en måde at være sammen på, hvor en indsats fra et medlem modtages og et ligeværdigt samspil 'går sin gang': "Der kan I se hvor klog jeg er" siger Karen (medlem Klub Fontana) med glimt i øjet, da hun forudsiger, at medarbejdernes ide om at ordne regnskab i Cafeen slet ikke giver plads nok. "Jeg kan godt se jeres ide om det sociale element, men vi kan slet ikke være der", tilføjer hun og giver medarbejderen et knus. Og i ansættelsesudvalget sidder medlemmer med, for "Det er jo de unge, der kan sige, om den pågældende ansøger er én de unge kan tænke sig at gå til med deres problemer - så det lytter vi rigtig meget til, når vi ansætter" (Ejvind, medarbejder Klub Fontana). 
Men som nævnt ovenfor adskiller Fontana sig også fra Fountain House. Det forstår jeg først og fremmest $\mathrm{i}$ forhold til, at Fontana er et Klubhus tilbud til en særlig gruppe, og må tilvirke modellens idegrundlag til deres medlemsgruppe - nemlig unge, med de behov unge har for relationer med voksne medarbejdere, og med de pædagogiske problematikker der er i spil, når de unge har særlig grad af psykisk sårbarhed inde på livet.

Fontana bruges af medlemmerne og er tænkt som noget, der kan bruges på en særlig måde. For eksempel indprentes det, at medlemmerne altid kan komme og bede om en samtale. Lis (medarbejder Klub Fontana) gør her i en MUS samtale tydeligt, hvad Fontana kan være for et sted for den enkeltes processer: Medlemmet fortæller, at hun ikke har det godt med medicinen, hun skal tage: "I starten syntes jeg det var helt forfxrdeligt, at jeg skal tage den, men nu ved jeg godt, at den hjælper"; "Hvis man kan fä et godt liv med medicinen, er det jo værd at tænke på-Men kunsten er at lære at leve med det; men det er noget af det, du kan bruge Fontana til", svarer Lis.

Det er medarbejdernes fokus på samtalerelationerne under mit feltstudie, der har ledt mig på sporet af forskelligheden. Den første feltstudiedag i Fontana giver Else (medarbejder Klub Fontana) sig tid til at fortælle mig om stedets udvikling. Hun siger, at de arbejder med en udvikling af Fontana, fordi de unge ikke har haft nok at beskæftige sig med med drift af Cafeen. Der har ikke været meningsfulde og omfattende arbejdsopgaver nok i Cafeen til at fylde alle medlemmernes hele dagligdag i Klubben. Dette kan tænkes at have ført til den 'kaffe-stue-hængen-ud', som medarbejderne omtaler som noget, de absolut ikke vil tilbage til, og den forskel som for eksempel medlemmet Asbjørn peger på mellem før og nu, når han siger, at han kan forstå, der foregår andre ting end at hænge ud nu.

Derudover fortæller hun, at der var en tendens til det, medarbejderne oplevede som 'smily faces' forstået som et overfladefællesskab af glade ansigter samtidig med, at der foregik stor og alvorlig samtaleaktivitet på tomandshånd mellem det enkelte medlem og kontaktmedarbejderen 'under overfladen'. Altså, et klubliv båret af en jokende stemning på overfladen og dækning af et omfattende relations-behov under overfladen.

Dette førte til indførsel af et program af skiftende aktiviteter med henblik på at flytte de underliggende processer ind i fællesskabet. Som en anden medarbejder udtrykker det: "Kontakten har været det bærende, men vi prøver at fä noget struktur, som kan blive det, der bærer noget af det hele" (Lis, medarbejder Klub Fontana). Altså, en proces, der handler om at skabe en meningsgivende indholdsside med aktiviteter.

For med alle de aktiviteter der er indført og medlemmernes ros heraf/ udtrykt behov herfor, som jeg har trukket frem i de foregående afsnit, kunne 
aktiviteterne i sig selv/udfyldelse af indholdssiden med aktiviteter, forstås som løsningen på det problem medarbejderne identificerede om det forholdsvis indholdstomme arbejdsdagsprogram, jokende overfladestemning og underliggende samtalevirksomhed. Altså, at man helt på linje med Fontæne Klubhusenes arbejdsorganisering for de voksne med sindslidelse laver en aktivitetsorganisering for Fontanas særlige medlemsgruppe af unge med psykisk sårbarhed - Det vil sige strukturerer dagen i henholdsvis aktiviteter, hvor det enkelte medlems processer kan foregå, mens medlemmet har travlt med aktiviteten blandet med pauser, hvor man kan trække sig og slappe af fra fællesskabet eller netop dyrke 'det sociale element', som det nu passer en bedst afhængig af 'dagsform' den pågældende dag.

Hertil kan man sige, at medlemmerne, med deres fokus på det gode ved aktiviteter frem for 'det private', faktisk bruger aktiviteterne sådan. For de planlægger at gå 'alene' i fitnesscenter den dag medarbejderne har medarbejderdag, de understreger, at det er aktiviteterne, der giver lyst til at stå op og komme i Klubben, og de engagerer sig for eksempel i at male og tage stilling til lys og skygge, farver og om 'det ligner' i maleraktiviteten - og giver respons "Jeg synes, det var rart at lave noget konstruktivt, noget hvor man skal koncentrere sig og bruge hovedet" (Laus, medlem Klub Fontana). På indfølende spørgsmål om "Hvordan var det?" fra medarbejderen besvares med "Det var rart", en ung der vil vende tilbage til klubben på grund af, at der nu er aktiviteter, selv om han nu er i gang med HF siger: "det er med små skridt ind $i$ noget, der ikke har med psyken at gøre" (Asbjørn, medlem Klub Fontana).

Men sagen er, at tanken fra medarbejdernes side jo er, at bestemte aktiviteter skal flytte indholdet $i$ 'de underliggende relationsaktiviteter' op i medlemsfællesskabet ved, at nogle (to-tre ugentlige) aktiviteter er 'særlige', det vil sige ligner en formaliseret udgave af den samtalevirksomhed, der før foregik under overfladen. Det er aktiviteterne Coaching, Fremtidsværksted og muligvis også Krafttræning.

Hertil kan man spørge om medarbejderne med deres fokus på aktiviteter, der bringer medlemmernes psykiske befindende ind i fællesskabet 'vender Klubhusmodellen på hovedet'? - Altså, ved at bringe 'det svære i tilværelsen' frem foran alles blik (for at skabe genkendelsen 'jeg er ikke den eneste, der har det elendigt og har besværligheder', eller for at fremme det gensidigt omsorgsfulde miljø, eller for den enkeltes vedvarende arbejde med egne processer).

Når jeg her spørger, til om det er 'at vende modellen på hovedet', er det, fordi det vedvarende er at have medarbejderne (frem for arbejdet/opgaverne/aktiviteterne) som omdrejningspunkt for medlemmernes processer (frem for aktiviteterne eller arbejdet), for det er medarbejderen, der 
stadig stiller sig til rådighed med redskaberne til sproglig fællesgørelse af medlemmernes presserende problemer.

Hermed bliver det de individuelle processer, der bliver samværets omdrejningspunkt i modsætning til, hvis det er 'det, man er fælles om' (Dagsprogrammets indhold) - hvor tanken er, at 'den man takker er sidemanden', fordi man i samarbejdet om opgaverne er 'nyttige for hinanden' frem for at være fokuseret på sig selv.

De pædagogiske begrundelser for ændringsønsket er dog også synlige og må på lige fod drages frem. Der kan nemlig være god grund til at ville ændre 'overfladestemningen'.

Medarbejderne siger selv, at de er i gang med en slags bøjning af standarderne i Fountain House modellen i og med, at de gerne vil gøre Fremtidsværkstedet og Coaching obligatorisk for alle medlemmer med begrundelsen, at "Det er svært at være groundet $i$ et fællesskab, hvor alle læringsprocesserne skal finde sted $i$ et kaos af frivillighed" (Else \& Felix, medarbejdere Klub Fontana). Således at frivilligheden, som er kendetegnet for Fountain House København, bliver mindre fremtrædende i Fontana. Altså, en strategi til at imødekomme det identificerede behov for struktur om, at de unge gerne vil vedblive med at komme i Klubben, hvis det ikke bliver for løst.

Man kan sige, at det er en anerkendelse af, at de unge har brug for omfattende støtte fra medarbejdere, der stiller sig synligt til rådighed, som er et anderledes behov end voksne, der har levet mange år med eller på vej ud af en sindslidelse som det gør sig gældende i Klubhusene som helhed.

Og så er det en strategi, der passer med Fontanas egen karakteristik, om hvor de er på vej hen med deres beskrivelse af sig selv som en slags skole, der arbejder med processer $\mathrm{i}$ form af kurser. Hertil kommer, at den grounding medarbejderne betegner deres faglige kvalitet ved ønskes udbredt til medlemmerne. Det kan forstås på linje med, at ydre orden kan afhjælpe indre kaos; men nu med fokus på 'problemerne' frem for på Dagsprogrammet.

På et Modelmøde for hele huset, som fandt sted, mens jeg var på feltstudie i Kontoret, kom det, via de unge, frem, at mobning er et af de aspekter, som hæmmer fællesskabet i Fountain House. Da jeg var på feltstudie i Fontana, spurgte jeg til ordet mobning, for det undrede mig, at det kunne forekomme i Fountain House overhovedet. Halfdan og Billy (medlemmer Klub Fontana) fortæller, at "Det er sådan set heller ikke mobning som sådan. Det er kammeratligt drilleri. Det er sådan en masse ironi af en slags, og det er der nogen, der ikke forstår ".

Således kan den pædagogiske begrundelse for at ændre 'overfladestemningen' være pædagogisk at varetage det omsorgsfulde miljø, Fontana gerne vil være. De unge medlemmer er socialt mere sårbare i deres livsfase og med den 'debuterende oplevelse af psykisk sårbarhed' er de også 
The Fountain House Way

- To beretninger fra hverdagslivet i tre Klubhus settings i Danmark

mere sårbare overfor omgangsformer, som kan være 'tvetydige' eller i det mindste ikke er helt tydelige. 


\section{Opsamling}

Gennem to feltberetninger fra tre Fontæne Hus settings (Fontæne Huset $\mathrm{i}$ Århus, Fountain House København og Klub Fontana i Fountain House København) er hensigten med rapporten her at bidrage med et praksisnært indblik i dagligdagen i de to typer Klubhus settings. Det vil sige henholdsvis det 'almindelige' Klubhusregi for voksne med sindslidelse og ungeklubben Klub Fontana for unge med psykisk sårbarhed.

Metodisk var grundlaget for analyserne feltstudiebaseret deltagende observation med fokus på medlemmernes og medarbejdernes samspil. Formålet var, gennem studier af samspil, at producere viden om, hvordan medlemmer og medarbejdere arbejder med og understøtter medlemmernes rehabilitering i Klubhusfællesskaber som ramme for/om medlemmernes rehabilitering. Fokus i feltstudierne og analyserne var derfor rettet mod det feltens mennesker gør sammen i ord og handling ud fra den analytiske strategi, at viden om det de gør sammen indebærer mulighed for at formidle noget om hvad der er på spil, det vil sige, hvad der er vigtigt for medlemmerne, og hvad den professionelle opgave består i i levet klubhusliv.

Medlems- og medarbejderkategorierne blev konstrueret som antropologiske relationelle kategorier, ved at forstå medlemmer og medarbejdere som noget de bliver via det, de gør sammen. Det ud fra den grundantagelse, at medlemmer og medarbejdere $\mathrm{i}$ samspil besidder forudsætningerne for at gøre medlemskab og medarbejderprofessionalisme og dermed Klubhuspraksis

Feltberetningen fra Klubhusene for voksne med sindslidelse i Århus og København havde som første delanalyse, at medlemmerne skal være arbejdsmotiverede, for at de kan siges at gøre levede medlemskaber i Klubhusene. Medlemmerne viser og udlever arbejdsmotivation ved at komme og bruge eller genoptræne den arbejdsevne, de har. Det vil i praksis sige, at medlemmerne bidrager og deltager i Klubhusenes organisering af samværsformer og dermed til husenes daglige driftsopgaver.

Hertil var det en pointe, at Klubhusenes arbejdsorganisering præcist imødekommer medlemmernes behov for at bruge den arbejdsevne, de kommer med. Men Klubhusene fordrer også af sine medlemmer, at de netop vil bruge deres arbejdsevne, hvis de vil være medlemmer. Dermed er Fontæne Klubhusene noget for nogen. Der ligger en forpligtethed til/hos medlemmerne om at 'sige ja' til arbejdsorganiseringen som det styrende. Klubhusene er 
dermed for nogle andre end dem, der har brug for et værested eller et behandlingssted. Hermed kan man sige, at Klubhusene udfylder en plads i psykiatrien, selv om Klubhusene pr definition ser sig i kontrast dertil.

Det var feltarbejderens oplevelse, at Klubhusmodellens udgangspunkt (som den udmøntes i hverdagssamspil) er, at 'medlemmerne kan' det de gerne vil. For fokus er via arbejdsorganiseringen hele tiden på medlemmets stærke sider, ressourcer og færdigheder til at indgå og bidrage. I det levede Klubhusliv finder medlemmer og medarbejder i samspil ud af, hvordan det enkelte medlem kan komme til at udleve sin arbejdsmotivation, og dermed bruge den arbejdsevne han/hun bærer ind i huset, hvormed medlemmet kan komme til at øves sig $\mathrm{i} / \mathrm{kunne}$ det, han/hun gerne vil.

Analysen viste, at stabilitet er vigtigt i Fontæne Klubhuse. Stabilitet viser medlemmets tilhør i Klubhuset, og stabilitet giver muligheder for udtryksmangfoldighed i måder at udleve arbejdsmotivation i hverdagslivet. For stabilitet kan imødekommes i en 'Klubhus organisering af samvær' (drift af huset er jo det, de er der for), mens ustabilitet kalder på forandring/opfordring til stabilitet. Ustabilitet kan ikke bruges til noget i Klubhusregi - Men Klubhusene giver medlemmerne mange muligheder for at gøre stabilitet, sådan at de kan have tilhør og bruge de muligheder, der er for den enkelte i et Klubhus drift og sociale program.

Det var helt tydeligt i feltstudierne, at det at være medlem ikke er en tilstand, men nærmere en daglig udfordring om at komme i husene og arbejde med stabilitet og bruge sin arbejdsevne til fællesskabets bedste.

I Klubhuspraksis viser levet stabilitet sig som kontinuitet. Kontinuitet betyder en forandringsmulighed for medlemmerne, for ved at blive del af kontinuiteten kan medlemmerne for eksempel få en hensigtsmæssig døgnrytme, øve til arbejdsmarkedet og opbygge sociale relationer. Analyserne viste, at inde i livet $\mathrm{i}$ Klubhusene er kontinuitet et fælles projekt båret af medlemmernes og medarbejdernes uophørlige gentagelse og dermed opretholdelse af Dagsprogrammet. Medlemmerne er, sammen med medarbejderne, bidragsydere til kontinuiteten.

Jeg fremanalyserede tre grader eller typer af medlemskab ${ }^{50}$. Det var henholdsvis om medlemmet på vej ind, det inde-forpligtede medlem og medlemmet som kunne være på vej ud, hvis det var tvingende nødvendigt.

\footnotetext{
${ }^{50}$ Opdelingen er selvfølgelig et analytisk træk. I praksis er medlemmerne ikke 'det ene eller det andet'. De indgår jo i forskellige situationer, der kræver noget forskelligt af dem. Ligeledes skal de tre typer/grader af medlemskab ikke forstås som en fortløbende proces. Et medlem kan for eksempel være inde-forpligtet $\mathrm{i}$ hele sit medlemskab. Analysen gør først og fremmest opmærksom på, at Klubhusene, medarbejderne og de øvrige medlemmer imødekommer flere forskellige medlemsbehov, der ligger indenfor det forpligtede medlemskabs rammer.
} 
I en proces på vej ind, altså i færd med at finde ud af at bruge huset til eget bedste via iværksættelse af sin arbejdsevne i Klubhusets rammer (altså imødekomme og sige ja til det Klubhusene står for), bruger medlemmet den ydre struktur, som Klubhusene helt tydeligt med organisering og omgangsformer signalerer, som støtte til at skabe stabilitet for sig selv.

Det inde-forpligtede medlem bruger den nu levede og særdeles velkendte struktur, og bidrager dermed i høj grad til den kontinuitet, der præger Klubhusenes hverdagsliv, til at finde muligheder $i$ driftsopgaverne til at arbejde med det den enkelte personligt 'har på programmet' (det medlemmet gerne vil komme til at kunne) i sin egen proces med eller ud af sin sindslidelse. Det er væsentligt at gøre klart, at det jeg her kalder 'den enkeltes proces' (altså, hvad det enkelte medlem har på tapetet i sit rehabiliteringsarbejde) ikke er i 'fællesskabets vidende' og dermed også er skjult for den deltagende observatør.

Det medlem der kunne være på vej ud, hvis det var tvingende nødvendigt, bidrager i ligeværdighed med medarbejderne til Klubhusenes drift ved at indgå 'fuldt og helt' i den mangfoldighed af arbejdsopgaver, driften af huset indebærer, såvel som til at opretholde Klubhusenes sociale omgangsformer om ligeværd og arbejdsfællesskab ved at forestå 'aktiviteter', der understøtter Klubhus-ånden (sidemandsoplæring, kontinuitet i arbejde og pauser, udadrettet arbejde nationalt og internationalt etc.).

Konklusionen var, at på den ene side arbejder medlemmerne med deres individuelle rehabilitering. Fontæne Klubhusene kan som sådan forstås som en ramme, hvor det er muligt, qua modellens fokus på kontinuitet, kollegialitet, støtte og plads til at hver enkelt kan komme og bruge sin arbejdsevne og føle sig ventet, ønsket og nødvendig.

På den anden side spiller fællesskabet en afgørende rolle. For det er med fællesskabet som fortegn, at medlemmerne bidrager med deres arbejdsmotivation. Den individuelle rehabilitering ser så at sige ud til at foregå, mens medlemmerne har travlt med at drive Klubhuset i fællesskab med de andre medlemmer og medarbejderne.

I hverdagslivet i Klubhusene ser der således ikke ud til at være noget modsætningsforhold mellem det enkelte medlems individuelle rehabiliteringsmulighed og modellens fokus på fællesskab og samarbejde (husets drift) - snarere tvært imod.

Det er medlemskab på The Fountain House Way, at medlemmerne arbejder med deres individuelle processer gennem brug af deres arbejdsevne. Dermed bidrager de til Klubhusets drift/fællesskabets bedste, hvormed de også bidrager til kontinuiteten, som præcist opretholder, at der er en ramme at komme og bidrage $\mathrm{i}$ for medlemmer på alle medlemsniveauer/i alle grader af medlemskab. 
Det er medarbejderprofessionalisme og socialpædagogik på The Fountain House Way at møde medlemmerne med mulighed for at bidrage. At stille opgaverne åbent frem og arbejde side om side og kollegialt med medlemmerne om husets drift. Og det er at være opmærksom på, at medlemmerne ved siden af deres bidrag til husets drift (i arbejde og socialt liv) har processer i gang, som kan støttes ved at være kollega, opretholde kontinuiteten og støtte deltagelsesmulighederne for medlemmerne, så de kan komme til at gøre noget 'af' deres situation, det vil sige deres liv med eller ud af en sindslidelse.

I feltberetningen fra Klub Fontana gav analyserne af feltmaterialet anledning til en tredeling i formidlingshenseende. Det var henholdsvis Klub Fontana som unge-milø, Klub Fontana som pædagogisk setting og Klub Fontana som Fontæne Klubhus for målgruppen unge med psykisk sårbarhed. Samlet set viste det sig, at en særlig opmærksomhed kan rettes mod betydningen af aktiviteter fra de tre forskellige formidlingspositioner det var at søge de unges perspektiv om, hvad der er særligt meningsfuldt i klublivet, et pædagogisk perspektiv på Klubben, og et perspektiv om Klubben som Fontæne Klubhus tilbud.

Først og fremmest er Klub Fontana et Klubhus tilbud til en særlig gruppe. Det betyder, at Klubbens medarbejdere må tilvirke Klubhusmodellens idegrundlag til netop deres medlemsgruppe - nemlig unge som ifølge medarbejderne for en stor dels vedkommende er meget syge. Det ser ud til, at medarbejderne søger at imødekomme dette ved at give mulighed for, at de unge kan engagere sig i aktiviteter af forskellig karakter, og give de unge medlemmer mulighed for at drøfte og samtale om de problemer, der rører sig $\mathrm{i}$ deres liv'nu og her'.

Klub Fontana som unge-miljø er et tilhørssted for de unge medlemmer, hvor de kan omgås hinanden $\mathrm{i}$ en ungdommelig stemning og med ungdommelige aktiviteter - de er der med deres alder og mødes som unge, der har de problemer, der hører ungdommen til. Særligt er de unges gensidigt omsorgsfulde tone, hvor de passer på hinanden og den stemning, de værdsætter og forbinder livet i Klubben med.

En af de ungdommelige aktiviteter der foregår i Klubben er 'at hænge ud'. Det kan synes ligetil for unge; men analyserne af feltmaterialet viser, at det særlige ved Klub Fontanas ungegrupper er, at det at hænge ud kan være svært. I den slags situationer bliver de unge konfronteret direkte med, at når man har det skidt og har psykisk sårbarhed inde på livet, er 'det sociale' svært.

Man kan sige, at det for unge med psykisk sårbarhed kan være forbundet med ubekvemhed spontant at skulle bidrage til og deltage i det sociale liv sammen med andre unge/andre mennesker. Derfor ser aktiviteter, frem for ubekvem 'hængen ud', ud til at være foretrukket af de unge. 
I analysen af Klub Fontana som pædagogisk setting ses, at medarbejderne tager de unges behov for aktivitet alvorligt ved at strukturere dagen i aktiviteter og give muligheder for deltagelse i opgaveløsning til fællesskabets bedste. Og at medarbejderne gør opgaverne både konkrete og synlige for de unge, som måske har svært ved selv at få øje på opgaver, muligheder for deltagelse og tage initiativ.

Medarbejderne fortæller, at de har arbejdet for at ændre Klubben fra et sted, hvor man først og fremmest hænger ud med hinanden til et sted, hvor Dagsprogrammet i form af aktiviteter og opgaver strukturerer dagen for de unge medlemmer. Medarbejderne i Fontana vil gerne fremme aktivitetstyper, hvor de unge inde i fællesskabet (frem for i 'alene-samtale' med en medarbejder) har mulighed for at arbejde med de problematikker, de slås med. Det blev på baggrund af analysen foreslået, at de unge og medarbejderne har forskellige prioriteter, hvad angår indholdet i aktiviteterne forstået på den måde, at de aktiviteter de unge foretrækker, holder 'det private' ude af fællesskabet, mens medarbejderne ser særlige pædagogiske muligheder i at inddrage problematikkerne i de unges liv 'her og nu' i fællesskabet.

I analysen af Klub Fontana som Fontæne Klubhus tilbud til unge med psykisk sårbarhed fortsatte analysen af betydningen af aktiviteter. På mange måder ligner Klub Fontana de øvrige Klubhuse, og med indførsel af aktiviteter til at strukturere dagen for medlemmerne, kan det siges, at Klub Fontana netop tilvirker Klubhusmodellen så den passer til medlemsgruppen: De unge medlemmer tilbydes aktiviteter, som kan understøtte deres arbejde med deres problematikker på samme måde, som medlemmerne i 'de almindelige' Klubhuse har husenes driftsopgaver. Men det blev også trukket frem, at de aktiviteter der særligt ønskes opprioriteret af medarbejderne er aktiviteter, som for det første tager problematikkerne med ind i fællesskabet (det er i modsætning til Klubhuspraksis i almindelighed), og for det andet har medarbejderne som facilisatorer (modsat at det er fællesskabet om at løse opgaven, gennemføre aktiviteten etc., der er katalysator for medlemmernes rehabilitering). Spørgsmålet er, om man søger at få de unge medlemmer til at tage ansvar for fællesskabet og udvikle sig af fællesskabet via en sammenholdsfølelse baseret på 'genkendelige psykiske besværligheder', frem for gennem meningsfyldt samvær omkring den type aktiviteter, de unge medlemmer selv ser ud til at vægte.

Konklusionen er, at det meget vel kan være, at medarbejderne med den særlige gruppe medlemmer (med debuterende sindslidelse, som for manges vedkommende er meget syge) er nødt til at finde strategier, der kan imødekomme de unges behov, som de unge måske ikke selv kan efterspørge. Altså, at medarbejderne qua deres faglighed ved, at de aktivitetstyper de søger at fremme, er gode for deres særlige gruppe af medlemmer. 
Men konklusionen er også, at det må være særligt væsentligt at være opmærksom på, hvad man tilbyder, og hvordan man vil hjælpe, jo mere afhængige medlemmerne er af stedet. Medarbejderne understreger selv, at de unge bliver ved at komme (de udfordrer strukturen, men de kommer hele tiden igen, hvis det ikke bliver for løst, fortælles det). Det kan tolkes sådan, at de unge netop har hårdt brug for Klubben. Man kan dermed forestille sig, at de unge vil komme 'næsten lige gyldigt hvad'. Det betyder, at medarbejdernes magt bliver desto større, fordi for de unge kan Klub Fontana siges at udgøre forskelsmuligheden på 'at ligge hjemme på sofaen', isoleret og have det skidt, og så være kompetent del af noget socialt og dermed fremtidsrettet og forhåbningsfuldt. Det er meget at give afkald på. 


\section{Referencer}

Broe, L (2003). Det etnografiske eventyr - fra laboratorium til eksperimentarium. I: Hammershøj et al. (red.): Mellemværender festskrift for LarsHenrik Schmidt. Danmarks Pædagogiske Universitetsforlag

Gulløv, E \& S. Højlund (2003). Feltarbejde blandt børn. Gyldendal

Hvid Jacobsen, M (2002). Social Science Fiction 'Opfindelse' overfor 'opdagelse' og 'retfærdiggørelse' I: Hvid Jacobsen, M, S. Kristiansen \& A. Prieur (red.): Liv, fortælling, tekst - Strejftog I kvalitativ sociologi. Ålborg Universitetsforlag

Hvid Jacobsen, M, A. Jørgensen \& S. Svendsen-Tune (2002). Sensitiv sociologi Undersøgelser af udsatte og udstødte mennesker. I: Hvid Jacobsen, M, S. Kristiansen \& A. Prieur (red.): Liv, fortælling, tekst - Strejftog I kvalitativ sociologi. Ålborg Universitetsforlag

Lov om Social Service: § 104 \& Kap 19 i vejledning nr. 95 til Serviceloven Punkt 233

Marcus, G (1998). Ethnography in/of the World System The emergence of multisited ethnography. I: Ethnography through thick and thin Princeton University Press

Nielsen, F. H (red.) (2006). Pædagogik og eksistens Om pædagogisk arbejde med psykisk syge. Billesø \& Baltzer

Robeyns, I (2005). The Capability Approach: a theoretical survey. In: Journal of Human Development. Vol. 6 no. 1 March 2005. Routledge

Statens Samfundsvidenskabelige Forskningsråd (2002). Vejledende retningslinjer for Forskningsetik i Samfundsvidenskaberne.

Steensberg, K (2010). Unges ensomhed bag facaden I: Information Debat Den 29.marts $2010 \mathrm{~s} .18$

Thomsen, O (2007). Fountain Houses i Danmark Fountain House Fonden \& Styrelsen for Specialrådgivning og Social Service. (www.servicestyrelsen.dk/wm142154)

Wadel, C (1991). Feltarbeid i egen kultur. Seek A/S Flekkefjord 
